NBER WORKING PAPER SERIES

\title{
THE JAPANESE BANKING CRISIS: WHERE DID IT COME FROM AND HOW WILL IT END?
}

\author{
Takeo Hoshi \\ Anil Kashyap \\ Working Paper 7250 \\ http://www.nber.org/papers/w7250
}

\author{
NATIONAL BUREAU OF ECONOMIC RESEARCH \\ 1050 Massachusetts Avenue \\ Cambridge, MA 02138 \\ July 1999
}

We thank Ben Bernanke, Ricardo Caballero, Menzie Chin, Peter Cowhey, Mitsuhiro Fukao, Mark Gertler, Peter Gourevitch, Yasushi Hamao, Masahiro Higo, Michael Hutchison, Tomohiro Kinoshita, Hugh Patrick, Joe Peek, Julio Rotemberg, Ross Starr, Robert Uriu, and Yaacov Vertzberger along with the participants of the presentations at University of Chicago, Graduate School of Business Brown Bag lunch, the NBER Japan Group, the Bank of Japan, the Bank of Italy, UCLA conference on the "Political Economy of the Japanese Financial Crisis", Federal Reserve Bank of San Francisco, and IR/PS at University of California, San Diego for helpful comments. We thank Raghu Rajan for providing data from National Survey of Small Business Finance, Itsuko Takemura from the Institute of Fiscal and Monetary Policy at the Japanese Ministry of Finance for providing data from Hojin Kigyo Tokei, and Simon Gilchrist, Kenji Hayashi, and Sumio Saruyama for helping us with other data issues. We thank Fernando Avalos, Yumiko Ito, John McNulty, and Motoki Yanase for excellent research assistance. Kashyap's work was supported through a grant from the National Science Foundation to the National Bureau of Economic Research. Hoshi's work was supported by a grant from Tokyo Center for Economic Research. Forthcoming in the NBER Macroeconomics Annual 1999. The views expressed in this paper do not necessarily reflect those of the Federal Reserve Bank of Chicago, the Federal Reserve System, or the National Bureau of Economic Research.

(C) 1999 by Takeo Hoshi and Anil Kashyap. All rights reserved. Short sections of text, not to exceed two paragraphs, may be quoted without explicit permission provided that full credit, including $\mathbb{C}$ notice, is given to the source. 
The Japanese Banking Crisis:

Where Did It Come From and How Will It End?

Takeo Hoshi and Anil Kashyap

NBER Working Paper No. 7250

July 1999

JEL No. G2, L8, E0

ABSTRACT

We argue that the deregulation leading up to the Big Bang has played a major role in the current banking problems. This deregulation allowed large corporations to quickly switch from depending on banks to relying on capital market financing. We present evidence showing that large Japanese borrowers, particularly manufacturing firms, have already become almost as independent of banks as comparable U.S. firms. The deregulation was much less favorable for savers and consequently they mostly continued turning their money over to the banks. However, banks were also constrained. They were not given authorization to move out of traditional activities into new lines of business. These developments together meant that the banks retained assets and had to search for new borrowers. Their new lending primarily flowed to small businesses and became much more tied to property than in the past. These loans have not fared well during the $1990 \mathrm{~s}$. We discuss the size of the current bad loans problem and conclude that it is quite large (on the order of $7 \%$ of GDP).

Looking ahead, we argue that the Big Bang will correct the aforementioned regulatory imbalances. This will mean that banks will have to fight to retain deposits. More importantly, we expect even more firms to migrate to capital market financing. Using the U.S. borrowing patterns as a guide, we present estimates showing that this impending shift implies a massive contraction in the size of the Japanese banking sector.

Takeo Hoshi

Graduate School of International Relations and Pacific Studies University of California, San Diego 9500 Gilman Drive La Jolla, CA 92093-0519

thoshi@ucsd.edu
Anil Kashyap

University of Chicago

Graduate School of Business

1101 East 58th Street

Chicago, IL 60637

and NBER

anil.kashyap@gsb.uchicago.edu 


\section{Introduction}

Japan's financial system is in the midst of a major transformation. One driving force is deregulation. The reform program that has come to be known as the "Japanese Big Bang" represents the conclusion of a deregulation process that began more than 20 years ago. By the time the Big Bang is complete, in 2001, banks, security firms and insurance companies will face a level playing field in which unfettered competition can occur. At that time, Japanese financial markets will be at least as liberalized as the U.S. markets and may be even less regulated.

A second (and we will argue related) driving factor is the current huge financial crisis. As of September 1998, the estimates of bad loans in Japan remain at 7 percent of GDP (see section four below for further details). This crisis has included the first significant bank failures since the end of the U.S. Occupation of Japan. In policy circles, the banking problems are widely identified as one of the key factors for the poor performance of the Japanese economy over the last couple of years. ${ }^{1}$ A growing academic literature suggests that the problems in the banking sector are now creating a serious drag on the economy's ability to recover. ${ }^{2}$

The Japanese government during the 1990s has taken a number of steps to address the financial problems. Starting with the loan purchasing program set up to acquire the failed banks in early 1993, followed by the establishment of banks to buy out failed credit co-operatives and the jusen, and culminating in the reforms that reorganized the supervision authority for banks and earmarked $¥ 60$ trillion for bank reorganization and capitalization, there have been a nearly

' For example, both the International Monetary Fund (IMF) (1998a) and Organization for Economic Cooperation and Development (OECD) (1998) country reports on Japan for 1998 point to the banking problems as a key factor in causing the post-November 1997 slowdown in growth. The Japanese government's 1998 Economic White paper also identifies problems in the financial sector an important factor in prolonging the recession (Economic Planning Agency (1998).)

${ }^{2}$ For instance, Bayoumi (1998) finds that fluctuations in asset prices played an important role in recent Japanese business cycles and that the shocks were mostly transmitted through bank lending. Without associated changes in bank loans, asset prices fluctuations would not have affected the real economy very much, he argues. Likewise Ogawa and Kitasaka (1998) report that small firms were especially hard hit by the decline in bank loans in the 1990s and that small and large firm investment differentials have emerged as the slow growth has continued. Motonishi and Yoshikawa (1998) find that the index of (firms' perception of) banks' willingness to lend (loose or tight) in BOJ's Tankan survey worsened substatially from late1997 and contributed to slow growth especially at small firms. Finally, Woo (1998) argues that since 1997 there has been a marked shift in bank loan supply that has contributed to the weak growth in 1997 and 1998. 
continuous set of rescues attempted. ${ }^{3}$

In the latest attempt, Long-Term Credit Bank of Japan (LTCB) and Nippon Credit Bank (NCB) were nationalized in late 1998, and three regional banks (Kokumin, Kofuku, and Tokyo Sowa) were put under receivership in the first half of 1999 . Their balance sheets are supposed to be cleaned up so that they can be sold. Meanwhile, in March 1999, 15 large banks applied for a capital injection and received $¥ 7.4592$ trillion of public funds. These banks are also required to carry out restructuring plans that will include eliminating 20,000 workers, closing $10 \%$ of their branches, and increasing profits by $50 \%$ over the next four years. ${ }^{4}$ Despite these programs critics, including the U.S. Treasury, have argued that these steps have been inadequate. ${ }^{5}$ Reports of government plans for another round of capital injections for regional banks in the Fall of 1999 are now circulating. As of this writing there is still wide spread pessimism about whether the banks have turned the comer.

We believe that a recurring problem with the Japanese government's attempts to overcome the crisis has been the lack of a clear vision for the future of Japanese banking system. For instance, the debate that culminated in the passage of the Financial Reconstruction Bill in the Fall of 1998 was drawn out because the ruling Liberal Democratic Party (LDP) and the major opposition party (the Democrats) haggled over two competing plans. On the surface, the negotiation seemed to center on what should happen to the Long-Term Credit Bank, which had been rumored to be insolvent for almost 4 months. At deeper level, however, the two plans represented competing views about the current condition of the Japanese banking system.

LDP leaders believed that the major banks could not be allowed to fail. To them, the biggest problem with the Japanese banks was they were not strong enough to support (supposedly) healthy customers. Thus, the desired solution was to inject public funds into the major banks as they did in March 1998, to prevent a credit crunch. In the event of a failure, protecting solvent borrowers, by transferring the failed bank's business to a bridge bank, was given the highest priority.

The Democrats argued instead that giving public funds to the weak banks was a waste of

${ }^{3}$ For a discussion of the loan purchasing program by the Cooperative Credit Corporation see Packer (1998). For a review of the jusen problems see Milhaupt and Miller (1997).

${ }^{4}$ For more details on the restructuring plans, see Choy (1999). Individual restructuring plans in Japanese can be downloaded from the Financial Reconstruction Commission website (www.frc.go.jp).

${ }^{5}$ For instance, Lawrence Summers, while he was U.S. Deputy Secretary of Treasury, was reported to have suggested to Hakuo Yanagisawa, chairman of the Financial Reconstruction Committee, that another round of capital injections may be necessary (Nikkei Net Interactive, February 26, 1999.) 
taxpayers' money. Weak banks should be nationalized and restructured. Through this process, the Japanese banking sector would reemerge smaller but healthier.

In the end the LDP and the Democrats reached a compromise and passed the Financial Reconstruction Act. This law allows the newly created Financial Reconstruction Commission to choose between nationalization and a bridge bank scheme when a bank fails. However, shortly thereafter, over the objections of the Democrats, the LDP also formed another coalition with the Liberal Party and managed to pass the Prompt Recapitalization Act to help recapitalize supposedly healthy banks. ${ }^{6}$

Thus, the struggle in the Diet during the Fall of 1998 amounted to battle over whether Japanese banking sector has too little capital or whether Japan is currently over-banked. To settle this issue one needs to ask what the banking sector will look like once the current crisis is over and the deregulation is complete. This question has attracted little attention. For instance, although there is now some discussion of how many large banks might be viable, aside from Moody's (1999) and Japan Economic Research Center (1997) (which we discuss in detail below) we are unaware of any other attempts to determine how many assets will remain in the banking sector. ${ }^{?}$

More importantly, the mergers and closures that have occurred thus far have not reduced capacity in the industry. If the over-banking hypothesis is correct, these adjustments will probably not help. Similarly, the latest capital injection plans required the 15 banks that received funds to reduce their general administrative expenses by $¥ 300$ billion, but at the same time to increase loans to prevent a so-called "credit crunch". We believe that one needs a clear vision of the future of the industry to evaluate this situation.

One of the primary contributions of this paper is an attempt to make some educated guesses about the future size of the industry. We hope that by providing these estimates we can inform the debate over how much assistance is reasonable to provide now. We believe that it is impossible to determine the appropriate level of resources to earmark for rescuing the existing banks without taking a position on what role the banks will play in the post-Big Bang economy.

To answer this question about the future, it is necessary to review the recent history of the financial system. In particular, we need to know how the Japanese banking system got into so much trouble. Having determined the cause of the current trouble we can then ask what will have to occur in order for the banks to get out of trouble. Based on our diagnosis, we can then assess what the financial system, particularly the banking system, will look like once the crisis is over.

${ }^{6}$ See Fukao (1999) for a summary and an analysis of the two laws and Corbett (1999a) for a more complete history of the policies leading up to the Fall 1998 legislation.

${ }^{7}$ For example, Atkinson (1998) argues that there will be only 2 to 4 major banks in Japan. We believe it is more important to focus on the size of the sector rather than the number of banks. 
The story that emerges from our investigation points to the nature of the deregulation leading up to the Big Bang as playing a major role in the banking crisis. During the Japanese high-growth era, usually dated from the mid-1950s through the mid-1970s, the financial system was regulated to steer both savers and borrowers towards banks. As growth slowed in the mid1970s a gradual deregulation process started. By the late 1980s this deregulation had eliminated many of the restrictions regarding large corporations' options for financing. During the 1980s these key bank clients began sharply reducing their dependence on bank financing. By the 1990s large Japanese firms' financing patterns had begun to look very similar to those of the large U.S. firms.

Meanwhile, innovation and the deregulation of the restrictions on households' investment moved much more slowly. Most Japanese savings into the late 1990s continued to flow into banks. The banks therefore remained large but had to search for new lending opportunities. The new lines of business that they entered turned out badly.

We conclude that the lopsided nature of the financial deregulation, combined with maturing of the Japanese economy and slow growth of the 1990s, created a disequilibrium situation that has lasted to date. To eliminate the disequilibrium, further deregulation of the financial system will be inevitable. Once the deregulation is complete, the Japanese allocation of savings and the investment financing patterns will move further towards the patterns seen in the U.S. We show this will imply a substantial decline in the prominence of the banks.

To paint this picture we divide the discussion into five parts. First, we review the regulatory conditions that prevailed prior to the Big Bang, focusing on the banking regulation that has governed the system over the last two decades. We argue that the regulation in Japan and the U.S. is converging and that the U.S. provides a sensible benchmark to use in forecasting what might happen in Japan. The following section of the paper provides some empirical support for this proposition. We show how past deregulation in Japan has altered firms' borrowing patterns and banks' activities. In section four we describe the current state of the banking industry. This brief section of the paper aims to clarify some common mis-perceptions about the current crisis and explain why there are so many different estimates of its scope. In section five, we look ahead and ask how much lending will be required if Japanese firms' borrowing patterns move closer to those seen in the U.S. Our calculations suggest that this will imply a sizable contraction in the traditional banking sector. Finally, in the conclusion we briefly discuss several scenarios for the transition between the current system and the eventual system.

\section{Financial regulation in Japan}

To understand the current conditions and to put the current rules in context it is necessary to briefly review some background information. Until the 1920 s, the Japanese banking system was characterized by free competition with little regulation. The Bank Act of 1890, for instance, set no minimum capital level for banks. A series of banking crises in the 1920s, especially the 
banking panic of 1927 , led the Japanese government to completely change its attitude toward regulating banks, and tight regulation of the banking sector began. Government regulation and control of the financial system intensified under the wartime economy.

This pattern continued during the U.S. Occupation of Japan. Indeed, some reform measures implemented during the Occupation, such as the Glass-Steagall style strict separation of commercial and investment banking, helped perpetuate the government's strong role in the financial sector. The financial system was also highly segmented. The regulatory framework that was completed during the Occupation period stayed more or less in place until the mid- $1970 \mathrm{~s}^{8}$.

During the high growth era from 1955 through 1973, banks dominated the financial system. Bond markets were repressed and equity issuance was relatively uncommon ${ }^{9}$. In the 1970 s this all began to change.

One big change was slower aggregate growth. Up until this time household savings were mostly channeled through banks to finance business investment. With lower growth the corporate funding requirements fell. The success of the Japanese economy in the rapid economic growth period also helped the corporations accumulate internal funds. This intensified the decline in the borrowing requirements of the companies.

A third feature of the economy in the 1970s was that the government began to run sizable deficits. The deficits arose because of a combination of slower tax revenue growth, a policy decision to engage in deficit spending to try to spur the economy, and an expansion of the Social Security System. To finance the deficits, the government significantly ramped up its bond issuance.

\subsection{Changes affecting savers}

The increase in the government bond issues changed the financial system. Previously the limited amounts of debt that were issued were sold almost exclusively to financial institutions. The coupon rates were low, but the banks and other buyers tolerated this because the total amount issued was small and other government regulation was protecting them from competition. Moreover, it was customary for the Bank of Japan to periodically buy up the government bonds from the financial institutions as a way to keep money supply growth in line with aggregate growth. But, the soaring debt issuance would have crushed the banks' profitability, if they had been forced to absorb all the low-yielding government bonds.

Thus, the Ministry of Finance was compelled to open a secondary market for government

${ }^{8}$ See Patrick $(1967,1971,1972)$ and Hoshi and Kashyap (1999) for further details.

${ }^{9}$ For instance, Patrick (1972) examined financial intermediation in this period and found that the "capital issue markets played a relatively minor role". (p. 112). 
bonds in 1977, and to start issuing some bonds through public auctions in 1978. The opening of the secondary market for government bonds, combined with accumulation of financial wealth at households during the rapid economic growth of the 1960s and the early 1970s, increased the demand for bonds. Moreover, many of the restrictions in the bond markets that had been put in place to ration funds during the high growth era now started to look out of date.

The expansion of the secondary market for government bonds undermined the interest rate controls that had been a prominent feature of the post-war financial system. Since the government bonds were now traded at market prices, investors and savers were able to stay away from the other financial assets, such as deposits, whose interest rates were set at artificially low levels. Thus, opening up the government bond market led to the liberalization of interest rates in many other markets. For example, interest rates in the interbank lending market, the tegata market, and the gensaki market were all freed from any regulation by the late 1970 s. $^{10}$ All the other interest rates except deposit rates were fully liberalized by the end of the 1980s. Starting with large deposit accounts, the deposit rates were gradually decontrolled during the 1980s and the 1990s, and were completely unrestricted by April 1993.

In addition to the interest rate deregulation there were several other steps that also gave savers better options. Money market mutual funds slowly began to appear and investing in other new instruments such as commercial paper eventually became possible. However, there was a lag between the time when bond financing and commercial paper issuance became common place and when savers could easily directly hold these securities. A summary of the major changes is contained in Table 1. The key conclusion from this table is that options for savers gradually changed and many restrictions survived into the late 1990s. As we will see these changes lagged the changes that benefitted borrowers and in several respects were not nearly as dramatic.

\subsection{Changes affecting borrowers}

Probably the biggest development for borrowers was the emergence of vibrant bonds markets both at home and abroad. In the domestic market, until the mid-1970s firms seeking to issue bonds had to secure approval from a body known as the Bond Issuance Committee. This group determined not only who would be allowed to issue bonds but also how much each issuer could raise. Firms seeking to issue bonds had to satisfy a set of financial conditions relating to size, profitability and dividend payments. In addition, bonds had to be issued with collateral.

The first step towards liberalization came in 1975 when the Bond Issuance Committee adopted a policy of honoring the requested amount of bond issues by each company. The collateral requirements also became gradually less important. In 1979, unsecured straight bonds

${ }^{10}$ In a gensaki transaction, a seller sells a security to a buyer with an agreement of repurchasing the same security at a certain price on a certain future date. The gensaki market is open for all corporations. In a tegata transaction, a seller sells a bill before its maturity to a buyer with discount. The tegata market is restricted to financial institutions. 
and unsecured convertible bonds were permitted, but the Bond Issue Criteria were so stringent that only two companies (Toyota Auto and Matsushita Electric) were qualified to issue. The criteria for unsecured bonds were gradually relaxed during the $1980 \mathrm{~s}$.

Several of the key developments played out in international markets. This first became possible because of the reform of Foreign Exchange and Trade Control Act in 1980. Foreign exchanges transactions, which were "forbidden in principle" under the old rule, were made "free unless expressly prohibited." The internationalization was further advanced in 1984 by the abolition of "real demand principle" which required the foreign exchange transactions to be backed by "real" demand for foreign exchange such as foreign trade. Following the suggestions in the Yen-Dollar Commission report, the Euro-market was substantially deregulated and the Tokyo offshore market was opened in 1986.

The foreign bond markets were attractive for Japanese firms because they made it possible to by-pass the Bond Issuance Committee. ${ }^{11}$ Perhaps most importantly, no collateral was required in foreign markets. This led to high levels of issuance in foreign markets. Warrant bonds, which were introduced in 1981 and allowed the holders to have an option to buy shares at a prespecified price during a certain period, were a leading example. Throughout the 1980s many warrant bonds were issued outside of Japan even though these securities did not prove to be very popular in the domestic market.

Liberalization also proceeded in the domestic market. By 1987 the domestic commercial paper market was created, giving firms another non-bank source of funding. By the late 1980s firms began to be able to avoid the bond issuance criteria if they were rated. Finally in 1996 all rules regarding bonds issues were lifted.

Over this period regulations regarding stock markets were also changed. Listing requirements were eased and commissions were eventually deregulated. These changes made equity issuance more attractive, although initial public offerings remained relatively expensive in Japan (see Jenkinson (1990)).

The key changes regarding the opening up of capital markets are collected in Table 2. Comparing this table and the previous one shows that the financing options for bank borrowers

"However, some self-regulation by the security houses continued so that firms in the 1980s were still forced to satisfy versions of the bond issuance criteria in order to be able to issue debt abroad. Although Japanese banks technically could underwrite foreign bond issues by Japanese corporations through the banks' foreign subsidiaries, the "three bureaus agreement" of 1975 suggested that banks should "pay due respect to the experience gained by and the mandate given to the Japanese securities firms." (Rosenbluth 1989, p.152) In practice, the three bureaus agreement has been interpreted to prohibit subsidiaries of Japanese banks from becoming the lead underwriters of bond issues by Japanese corporations. Thus the Japanese banks did not have much say about the self regulation of foreign bond issues. 
opened up much faster than the options for savers. As we document, below by the end of the 1980 s many of the banks' traditional clients had already migrated to cheaper bond financing. One striking statistic is that during the decade the number of firms permitted to issue unsecured domestic bonds grew from two to over 500 .

The third leg of deregulation dealt with changes in bank powers. The major changes are shown in Table 3. We draw three important lessons from the list. First, the bank powers were expanded very slowly and gradually. While the banks' main borrowers were able to quickly get into the bond market, the banks had their hands tied in many respects. For instance, securitizing loans was not even possible until 1990. Second, many new types of businesses, particularly feegenerating activities, did not become available until relatively recently. For example, through 1998 Japanese banks were still prohibited from collecting fees by offering loan commitments! Thus, banks in Japan were essentially forced to continue to try to make money through conventional deposit-taking and loan-making during the 1980s. Finally, even up until the end of 1990s there were significant barriers which continued to keep investment banking and commercial banking separated in Japan.

The culmination of the deregulation is the Big Bang. ${ }^{12}$ When the government first proposed the program in the Fall of 1996, it was heralded as drive to make Japanese financial markets "free, fair and global". As we describe more completely below, the result will be that banks, insurance companies, and securities dealers will all be able to directly compete.

\subsection{Comparisons with the U.S.}

As we look ahead we foresee these changes pushing the Japanese financial system to become more similar to the U.S. system. In fact, ever since the U.S. Occupation of Japan there has been a certain degree of similarity between the financial systems in the two countries. A key reason for the similarity is that Article 65 of the Securities and Exchange Act was passed in March of 1947 with the intent of mimicking the U.S. Bank Act of 1933 (Glass-Steagall). Both laws mandated a separation of investment and commercial banking. This separation has constituted a defining feature that separates the two financial systems from others in Europe and has shaped the evolution of both systems. In what follows, we argue that not only has the evolution been similar but that the banks in both countries are going to become even more similar in the future.

The Japanese banks have traditionally been more successful than the U.S. banks in their attempts to participate in investment banking activities. For instance, the banks were able to play the role of trustee of collateral in the bond underwriting process in Japan while they were mostly shut out in the U.S. Similarly, Japanese banks were able to take limited equity positions in the firms to which they were lending. However, as Dale (1992) points out, like the U.S. banks, the

12 There are many good summaries of the provisions of the Big Bang. Two recent guides are Craig (1998) and Toyama (1998). See Takeda and Turner (1992) for an overview of the earlier changes. 
Japanese banks were "excluded from market-making in and the public distribution of corporate securities". This constraint kept the Japanese banks from becoming full-fledged, German-style universal banks. Instead the Japanese financial system, like the U.S. system, was fragmented with banks, insurance firms, and securities firms each maturing while facing little direct competition from each other.

Within the banking system in each country there was further segmentation. In the U.S., cross-border branching was restricted until recently so that banks could not compete on a nationwide basis. Similarly in Japan, competition between City Banks, trust banks, regional banks, long-term credit banks, and other small banks such as credit unions, has traditionally been restricted by legal measures and administrative guidance by the Ministry of Finance.

Beyond the segmentation, there are further similarities in the ways that the bank powers in the two countries changed over time. In both countries, the drive by the commercial banks to reenter investment banking has taken more than 50 years. During this period the deregulation process has been slow and incremental. In the U.S. for example, banks were allowed to enter investment banking through subsidiaries only in 1987, as regulators began to re-interpret Section 20 of the banking laws that prohibit banks from having affiliates that are "principally engaged" in non-banking activity. Over time the permissible fraction of bank income accruing from the socalled "section 20 subsidiaries" has slowly risen.

In Japan, the Financial System Reform in 1993 made it possible for banks to enter security business through subsidiaries, but the actual establishment of bank-owned security subsidiaries was only gradually permitted over the next couple of years. The range of security services that these subsidiaries can provide is still limited and the limitations will be incrementally removed between now and 2001 .

Importantly, as the banking deregulation proceeded in Japan there was discussion over whether a shift toward permitting universal banking would be desirable. In March 1989 the Ministry of Finance convened an advisory group dubbed the "Second Financial System Committee of the Financial System Research Council". This group described five possible routes towards permitting more integration of commercial and investment banking: separatedsubsidiaries, multi-functional subsidiaries, holding companies, universal banks, and a piecemeal approach. According to Committee "the sight of banks pushing out in every direction in pursuit of high returns, even at high risk, might shake peoples' faith in them." Thus, the Committee recommended against a universal banking approach. Ultimately in 1993 the separated-subsidiary approach was adopted. Later in 1997, relaxation of Section 9 of the Anti-Monopoly Act made it possible to establish a financial holding company.

As the turn of the Century approaches, firms trying to offer one-stop financial shopping are facing fewer and fewer barriers in both countries. In Japan, as a result of the Big Bang, it is already possible to create a holding company that can span the securities and insurance industries. By April 2001 it will be possible to bring banking into the same holding company. 
In the U.S. legislation to repeal the Glass-Steagall provisions have been intensively debated in the last several Congresses. With the Citigroup merger it seems inevitable that current legal impediments that separate commercial and investment banking will end shortly. Indeed, most of the U.S. discussion now centers on how to allow banks to enter the securities industry and not on whether to allow it. So it is safe to assume that in near future the regulatory conditions in both countries will be very similar.

Once the deregulation in both countries is complete, a transition featuring competition among entrenched securities firms, insurance companies, and banks will begin. Table 4 shows the Japanese financial services alliances that were announced in 1998 and early 1999. This early evidence suggests that a scramble is already underway to provide much broader services than have been available in past. The same sort of tie-ups are occurring in the U.S. The table also shows that foreign institutions are aggressively entering the Japanese market.

Collectively these patterns suggest that banks in the two countries are going to face the same types of competitive pressures and will have same sort of options available to respond to the pressures. Although the Japanese banks start from a much weaker capital position than the U.S. banks, it is hard to see why the bank activities in the two countries will not become similar.

\section{An empirical look at the fallout from the deregulation}

To support our contention that Big Bang is going to push the financial system in Japan to look more like the U.S. system, we examine several pieces of evidence. For organizational purposes it is convenient to separate the discussion into the responses of the borrowers, savers and lenders. We will see the behavior of large and small borrowers turns out to be quite different. On the bank side we will distinguish between the portfolio adjustments that were made and the new business opportunities that were missed. For the savers we will see that the deregulation prior to the Big Bang has not made a big difference.

Throughout most of our discussion we will emphasize the importance of regulatory shifts. This choice does not mean that we doubt the importance of other factors such as macroeconomic conditions. In fact, it is quite reasonable to assume that the deregulation may have contributed to the fast growth of lending in the late 1980s that preceded the long recession of the 1990s. However, for the purposes of looking ahead we do not believe that it is necessary to separately identify the role of macroeconomic factors. Our basic point is that the past deregulation did have some independent effects and that based on the responses to past deregulation that it is reasonable to expect that the Big Bang will have a large effect as well. Thus, our empirical work is aimed at showing that regulatory shifts have a clear, independent influence on borrowers, savers and banks. ${ }^{13}$

${ }^{13}$ There are several studies that focus on drawing a more comprehensive picture of what caused the current banking problem in Japan. Cargill, Hutchison and Ito (1997) list both macroeconomic conditions generated by loose monetary policy in the late 1980s and reduced 


\subsection{The response of borrowers to financial market deregulation}

It is widely recognized that part of the reason why banks in Japan got into trouble is that they lost many of their best borrowers in a very short period of time. ${ }^{14}$ As mentioned earlier, between 1983 and 1989 the Japanese bond market blossomed, permitting many internationally known companies to tap the public debt markets for the first time. While this story is wellknown, we are unaware of any attempts to compare the bank-dependence of large Japanese and U.S. firms before and after the deregulation. We provide evidence that the Japanese deregulation has permitted the largest Japanese firms to become almost as independent of banks as their U.S. counterparts.

A major challenge in conducting this investigation is the limited availability of comprehensive data on bank borrowing by firms. In Japan there are essentially two types of data that can be used. For exchange-traded firms, the corporate financial statements that are publicly available generally break out bank borrowing. This means that for these (typically) large firms one can get fairly good data. As an example, the Japan Development Bank Database provides this type of information on over 2000 firms for 1997.

To learn anything about unlisted companies one must rely on survey data. The most comprehensive survey that we know of on this topic is conducted by the Ministry of Finance and published in the Hojin Kigyo Tokei Kiho (Quarterly Report of Incorporated Enterprise Statistics). The cross-sectional coverage of these data is excellent. All non-financial corporations with book capital of $¥ 1$ billion ( $\$ 8.33$ million using the exchange rate of $120 ¥ / \$$ ) are included in the survey. ${ }^{15}$ The remaining (small corporations) are randomly sampled with sampling factors that depend on their size. Only very tiny firms (those with less than $¥ 10$ million in capital) are completely excluded. We believe that the survey is sufficiently comprehensive so that it essentially side-steps the selection problems associated with using listed data. ${ }^{16}$

The main drawback with the survey information is that data for firms with similar amounts

corporate dependence on bank financing, which we focus, as contributing factors to the problem. They also list other factors such as government deposit guarantee and regulatory forbearance. Cargill (1999) gives a similarly comprehensive list. By estimating some cross-section regressions, Ueda (1998) confirms the importance of both macroeconomic conditions and financial deregulation to have been important factors in bringing about the banking problem

${ }^{14}$ For instance, see Cargill, Hutchison, and Ito (1997), Cargill (1999), Ueda (1998), Lincoln (1998), Hutchison (1998), and Hoshi and Kashyap (1999).

15 In what follows we use this exchange rate. We use GDP deflators when it is necessary to convert nominal amounts into real amounts.

${ }^{16}$ For example the 1997 fourth quarter survey was sent to 23,475 firms and the response rate was over $80 \%(19,007)$. 
of capital are aggregated, so that no firm-level statistics are accessible. Unfortunately, all the size thresholds used in the MOF data are based on nominal thresholds, so that over time (as the price level rises) firms drift into the upper grouping, even if their size measured in constant prices is unchanging. We discuss the impact of this limitation in the places where we believe it might be important.

In our analysis we focus on the ratio of (the book value of) bank debt to (the book value of) total assets as the basic measure of the importance of bank financing. We scale by assets to eliminate pure size differences. ${ }^{17}$ Below we also show some results which distinguish among different industries. The industry comparisons can be motivated in many ways, including as an attempt to correct for industry-level differences in risk and collateralizability of assets.

Table 5 shows the ratio of the bank debt to total assets based on the MOF data for different-sized Japanese firms over time. The data pertain to the second quarter of each year between 1980 and 1998. In addition to showing data for all industries, the table also displays separate series for manufacturing, wholesale and retail trade, and all other firms. The largest firms which are separately identified in the sample are those with a book value of equity greater than $¥ 1$ billion in current prices. In the second quarter of 1998 the 5,363 firms in this category had average assets of $¥ 112$ billion. ${ }^{18}$

The table reveals a consistent pattern of large Japanese firms scaling back their bank borrowing. The shift has been most pronounced among manufacturing firms where the ratio of bank debt to assets has dropped by almost $50 \%$. Moreover, notice that the shift was effectively complete by 1990 -- since then ratio has been roughly constant. This timing suggests that the banks saw many of their traditional clients taking-off soon after the opening up of the bond market.

${ }^{17}$ This ratio can also be thought of as the product of the bank debt to total debt ratio and the total debt to total asset ratio. This decomposition distinguishes the total amount of leverage from the sources of financing for borrowers. For our purposes we believe this distinction is not very helpful since the banks presumably care about their total lending. To a first approximation it probably does not matter if they are losing business over the kind of long periods that we are studying because of overall de-leveraging as opposed to more competition from other funding sources.

We also checked that using book value data would not paint a misleading picture. A quick comparison of national income accounts data in Japan and the U.S. suggested that the gap between the current value of assets (the analog to market value) and the historical value was similar in both countries. Thus, we see no obvious biases from using book value data for both countries.

${ }_{18}$ Of the 5,363 large firms, 2,192 were in manufacturing, 941 were in trade (wholesale or retail), and the remaining 2,230 were in other industries. There were $1,161,179$ small firms in the 1998 survey, with 232,313 in manufacturing, 363,707 in trade, and 565,159 in the other industries. 
There was also a substantial drop in bank dependence for the trade firms. In publicly available versions of the survey all trade firms are shown together, but the Ministry of Finance provided us with unpublished data for selected years which allow us to separate wholesale trade companies from the retail trade companies. Based on the unpublished data we learned that the drop in bank dependence is more pronounced for retail trade firms than for wholesale trade firms. For instance, between 1980 and 1998 the large retail trade companies cut their bank debt to asset ratio from 0.35 to 0.26 , while the wholesale firms ratio dropped from 0.35 to 0.30 . Table 5 also indicates that remaining large firms hardly changed their bank borrowing.

To explore the impact of the nominal thresholds we also looked at other data for listed firms. In Table 6 we report analogous statistics in which we define large firms to have real assets (measured in 1990 prices) to be greater than $¥ 120$ billion ( $\$ 1$ billion). Using this consistent size definition, the manufacturing firms show an even more pronounced shift away from bank debt. The larger drop is partly expected since the nominal size thresholds in the MOF survey data will cause some smaller firms (which are presumably more bank-dependent) to drift into the large firm category over time.

The third and fourth columns in table 6 shows the patterns for large, listed wholesale and retail firms. The retail firms show the same general pattern as the manufacturing firms, although the drop in bank dependence is less pronounced. For the listed wholesale trade firms the bank debt to asset ratio drifted up noticeably in the 1980s, before beginning to decline in the $1990 \mathrm{~s}$. This non-monotonic decline can be traced to the behavior of the nine large general trading firms and is not representative of other wholesaling companies. For instance, the trend disappears when these nine firms are omitted and the aforementioned unpublished MOF data showed a slight overall drop in bank dependence. ${ }^{19}$ The final column in the table that shows that the remaining large, listed firms have also cut their bank borrowing.

The two tables together show a clear pattern of rapid adjustment by the large firms (except for possibly a few wholesale trade companies). Notice in Table 6 that for all the sectors where bank dependence was falling, the bank debt to asset ratios in 1990 and 1998 were about the same, so that in fact much of the adjustment had occurred before the onset of slow aggregate growth.

In contrast, among the small firms there has been no clear reduction in bank dependence. Indeed, Table 5 shows that in each of the major sectors the smaller firms have become somewhat

19 The nine companies in question are Mitsui Bussan, Itochu, Kanematsu, Sumitomo and Company, Tomen, Nissho Iwai, Nichimen, Marubeni, and Mitsubishi and Company. When they are excluded the level of bank debt to assets is much lower in most years (e.g. 0.248 in 1998 as opposed to 0.431) and the level in 1998 is slightly lower than the level from the early $1970 \mathrm{~s}$. We have heard several anecdotes suggesting that this discrepancy arises because the large trading companies took on considerable bank debt in the 1980s in order to set up subsidiaries to enter the real estate business. 
more bank dependent as the deregulation has progressed, although in manufacturing and in the "other" sector small firms' bank dependence is below the peaks that occurred in the late 1980s and early 1990s. As we discuss below, we believe that some of these patterns are attributable to the fact that the banks themselves did not shrink much as the deregulation proceeded.

One question raised by these patterns is what they imply for the future of relationship financing in Japan. The data in Tables 5 and 6 clearly show that even before the Big Bang had taken place, the large Japanese firms had cut their bank dependence. Tight dependence of large firms on their banks was probably the most unusual aspect of the Japanese financial system. ${ }^{20} \mathrm{~A}$ growing literature (e.g. Petersen and Rajan (1994), Berger and Udell (1995)) shows that relationship financing for small firms is quite prevalent also outside of Japan. It appears that any relationship financing that will continue in Japan will be more like what is observed elsewhere in the world.

To put the size of the shift in behavior of the large firms in perspective, we offer a comparison with financing patterns in the U.S. This effort is complicated because of the absence of completely comparable data for the U.S. Contrary to the conventions followed in Japan, there are no standard sources that provide firm-level information on firms' bank borrowing. U.S. firms do sometimes identify bank lending in the footnotes to their financial statements, but databases such as Compustat do not report such information. So we cannot report data which would be comparable to Table 6.

The only broad-based U.S. data on bank borrowing patterns comes from a survey conducted by the Census Bureau called the "Quarterly Financial Report for Manufacturing, Mining, and Trade Corporations" (QFR). ${ }^{21}$ The QFR contains the financial statistics for corporations aggregated by industry and by size. Like the MOF survey, the size thresholds are based on nominal thresholds, although the QFR size cutoffs are based on assets rather than capital. The coverage of the QFR for manufacturing industries is outstanding. All the corporations with total assets of $\$ 250$ million and over are included in the survey. Smaller firms are randomly sampled with sampling factors ranging from $1 / 2$ to $1 / 160$, depending on their sizes.

Unfortunately the QFR coverage beyond manufacturing is quite limited. For firms in three industries (mining, wholesale trade, and retail trade) all the corporations with total assets $\$ 250$ million and over are included, but small corporations are intentionally excluded. Since 1988 the definition of small has been set so that no corporations with total assets under $\$ 50$ million are included; previously, between 1981 and 1987, this threshold had been $\$ 25$ million in current

20 See Aoki and Patrick (1994) for a comprehensive study of the tight dependence of Japanese firms on bank financing. There is no contradiction in saying that the past relationships for the large firms may have been valuable but were not sustained after deregulation. This will be the case if as capital markets improved, the costs of being tied to the banks was rising. See Hoshi and Kashyap (1999) for further discussion on this point.

${ }^{21}$ See Gertler and Gilchrist (1994) for more discussion of the QFR. 
prices. This prevents us from examining the financing pattern of small firms outside manufacturing. Moreover, for industries that are not covered by the QFR (e.g., transportation, communication, services, construction, etc.), we cannot get data even for large firms.

It is fairly straightforward to find a breakpoint in the QFR data that can be compared to the Hojin Kigyo Tokei Kiho data described in Table 5. Recall from Table 5 that the average asset size of the large Japanese firms was $\$ 934$ million in 1998. According to QFR for 1998, the average size of total assets for manufacturing corporations with assets $\$ 10$ million or above was $\$ 1,020$ million. Thus, it appears that "large" firms in Table 5 are roughly comparable to QFR data for firms with total assets of $\$ 10$ million.

Table 7 shows that bank debt to asset ratio data reported in the QFR from 1979 through 1997. Columns two through four show data on all manufacturing firms and then large and small manufacturing firms respectively. We draw three conclusions from this part of table. First, and most importantly the time series variation in bank dependence in the U.S. data is much less noticeable than in the Japanese data. Second, for the large firms there has been a slight upward drift in the bank debt to asset ratio. Consequently the bank dependence of the U.S. and Japanese large firms is much closer now than in the 1980 s - we explore this further below. Third, the small manufacturing firms in the two countries do not seem to be converging in their borrowing behavior. The small U.S. manufacturing firms have held steady with a ratio of bank debt to assets between $16 \%$ and $19 \%$. In contrast, the small Japanese firms' ratio of bank debt to assets has crept up from about $29 \%$ to $35 \% .^{22}$

The remainder of Table 7 provides information on borrowing patterns by wholesale and retail trade firms. Interpreting these figures requires some care since the universe of firms included in the sample has changed so much across years - see the footnotes to the table for details. Despite these changes it seems safe to conclude the very large non-manufacturing firms in the U.S. are still much less bank dependent than similar firms in Japan.

One potential concern with Table 7 data is that the nominal size thresholds may be responsible for some of drift upwards in the large manufacturing firms' bank dependence. Unfortunately, we were unable to obtain any unpublished data from the U.S. Census Bureau to directly check this. However, based on the checks which we were able to perform using published data this does not seem likely to be too much of an issue. For instance, it is possible to study manufacturing firms with more than $\$ 1$ billion in assets. Within this sample the firms which drift into the category should already be quite large and have a low level of bank dependence. This sample of firms shows the same basic patterns as in Table 7: bank dependence rises in the late 1980s and then falls in the 1990s, but remains at a higher level than in 1980.

Comparing tables 5 and 7, we find that the bank dependence of the large Japanese firms

22 Toward the end of the 1990s, however, the bank-dependence of the small Japanese manufacturing firms did decline. We expect this pattern to continue after the Big Bang. 
has become closer to that of comparably-sized U.S. firms, particularly in manufacturing industries. The convergence, however, still looks incomplete. One possible reason for this may be crosscountry differences in the industrial structure. Average bank debt to asset ratios vary considerably across industries. For instance, in the $1998 \mathrm{MOF}$ data shown in Table 5, the range of bank debt to assets ratios varies between 0.09 and 0.42 across manufacturing industries (using 2-digit SIC codes to identify industries). This type of variation is not surprising given the differences in riskiness and collateral of different industries. Such variation will probably persist even after the Big Bang. Therefore one would only expect convergence in the bank debt to asset ratio for the entire manufacturing sector if the asset distribution across industries is the same in both countries. This suggests that it is advisable to study the borrowing patterns at the two-digit industry level (or finer).

One problem with looking to industry level data is that there is less detail on the size distribution of firms within industries. The published QFR data only show separate information for firms with assets above and below $\$ 25$ million. The published Quarterly Report of Incorporate Enterprise Statistics includes no information on different sized-firms in each industry. By getting unpublished data from Japan we were able to make some very rough comparisons. ${ }^{23}$ The Japanese data cover firms with capital above $¥ 1$ billion so there is a slight size mis-match in the comparison. ${ }^{24}$ The overlap in industrial classification definitions allows us to match 14 industries (food, textile, pulp/paper, printing/publishing, chemicals, petroleum/coal products, stone/clay/glass, iron/steel, nonferrous metals, fabricated metal products, machinery, electrical/electronic machinery, transportation equipment, and precision machinery).

Table 8 reports information on how large Japanese firms' bank dependence has compared with U.S. firms' bank dependence over time. For the Japanese firms we show the bank debt to asset ratio in 1980 and 1998. Since there is no noticeable trend in the U.S. data, we report only the 1998 levels for the U.S. industries - using other years or an average of several years made no difference in what follows. The last two columns of the Table show the difference for each of 14 industries in two periods. In 1980, the difference was diffusely distributed between 0 and 0.56 . For average industry the difference was 0.197 . The table shows that by 1998 the distribution had become much more concentrated around zero. By 1998, for ten out of fourteen industries, the Japanese bank debt ratios are within 10 percentage points of the U.S. ratios. Moreover, for these ten industries the distribution of differences in bank dependence is more symmetric, with three of the ten Japanese industries appearing less bank dependent than their U.S. counterparts.

Interestingly the four industries where convergence has not occurred (pulp/paper, nonferrous metals, petroleum, and iron/steel) are all cases where a significant portion of the

${ }^{23}$ We thank Itsuko Takemura for providing these data.

24 The $¥ 1$ billion cutoff is closer to a $\$ 10$ million cutoff. However, using the published data on all manufacturing firms we verified that the firms with between $\$ 10$ and $\$ 25$ million in assets are of limited importance. Thus, we believe that the size mismatch is not likely to mislead us about the general trends in bank dependence in the two countries. 
Japanese firms have performed poorly. ${ }^{25}$ We believe that for these depressed industries the effects of deregulation are likely being masked by the poor profitability of the firms; going to public debt markets is always hard for financially troubled firms. Overall we read the industry-level comparisons as further suggesting that large Japanese and U.S. manufacturing firms have become fairly similar in their bank dependence.

Table 9 shows a comparable set of industry differences for small manufacturing firms. The contrast with the previous table is striking. For the small firms there is no sign of convergence, and if anything the differences are larger than in 1980. However, the differences were even larger in 1993, so the relative gap is now closing. Nevertheless, there is still a long way to go.

\subsection{Savers response to the deregulation}

An obvious question is why did the small and large borrowers fare so differently. We believe that the key to understanding the difference comes from looking at the behavior of the banks' depositors. Japanese households have historically held the dominant part of their financial assets in bank deposits. The conventional explanation for this (e.g. Hamada and Horiuchi (1987)) was the relatively low overall level of financial assets held by the households along with the high transactions costs of operating in an immature capital markets. Table 10, which shows the ratios of bank deposits to GDP for G7 countries, suggests that at the onset of deregulation in 1983 Japan had much more bank deposits (relative to GDP) than any other G7 countries. The total deposits to GDP ratio stood at 1.58 , more than double the ratio for Italy, the next highest country.

The table also shows that by 1996 the picture had hardly changed. Japan still looks anomalous based on the deposit/GDP ratio. Figure 1 shows yearly data for the City Banks and confirms that there was no unusual breaks in the pattern and that even the large commercial banks were gaining deposits (relative to GDP) in the last two decades. The fact that deposits at the City Banks account for only about ten percent of the deposits recorded in the IMF data is one way of seeing the importance of postal savings accounts. As we discuss below, forecasts of the future of the banking system need to be conditioned on what will happen to the postal savings accounts.

Why didn't the Japanese savers prune their bank deposits? One answer is that the deposit to GDP ratio may not tell the complete story. The last column in Table 10 shows that the ratio of deposits to wealth fell from $67 \%$ in 1983 to $62 \%$ in 1996 . So from the households' perspective they did cut back slightly on their use of banks. Nevertheless, there does seem to be a puzzle as to why the banking reliance remained so strong, particularly since there were so many steps taken to liberalize financial markets during this time.

We believe that there were several features of the deregulation process that kept the savers from pulling their money out of the banks. First, the deregulation process was very slow in

${ }^{25}$ We thank Bob Uriu for pointing this out. 
allowing individual investors easy direct access to capital markets. For example, participating directly in the stock market remained expensive for individuals until very recently. Up until April 1998 , commissions on trades as large as $¥ 50$ million were still fixed and regulated. Only in October 1999 will all commissions be fully deregulated. Similarly, a range of activities including stock options trading by individuals, over-the-counter trading of equity related derivatives, and trading non-listed stocks through securities firms were prohibited until December 1998. So prior to the Big Bang it was very costly for individual investors to participate in capital markets directly.

But, the limited direct access only partially explains the individuals strong attachments to bank deposits. One obvious question is why didn't investment trusts (which have existed for many years) draw money away from banks? Here again regulation was important. Until 1998, investment trusts in Japan were limited to contract type funds, and company type funds (i.e. U.S. style mutual funds) were not allowed. Furthermore, any investment trust had to be sold to more than 50 investors, precluding the possibility of establishing funds specialized for a few rich investors, like many hedge funds, vulture funds, and LBO funds in the U.S.

More importantly, entry into the investment trust business was limited by other regulations. This protection muted some of the incentives to improve the returns on investment trusts. Since almost all the investment trust companies were subsidiaries of securities companies, they were often interested in churning all the accounts they managed to collect the high commissions for their parents. Consequently the investment trusts had a poor track record, generally under-performing market indices by large margins (Cai, Chan and Yamada (1996), Ohmura and Kawakita , Chapter 7 (1992), and Yonezawa and Maru (1984), p.31.)

Other financial services companies were barred from offering investment trusts until the 1990s. But even in the 1990s, when the entry barriers finally started to be removed, the investment trust companies were still required to get government approval each time they set up a new investment trust fund. The restriction remained until December 1998 and stifled competition to introduce innovative products. ${ }^{26}$

We believe these factors together significantly limited the options of savers and led them to keep much of their money in the banks. Notice that our explanation does not emphasize any attempts by banks to attract funds to take advantage of their deposit insurance guarantees. This does not imply that we completely dismiss the moral hazard stories that have been emphasized by others (e.g. Cargill, Hutchison, and Ito (1997), Hutchison (1998) ). Rather, we believe that our complementary explanation stressing the limited degree to which savings options were deregulated has been overlooked.

${ }^{26}$ When a career official at Ministry of Finance was arrested for corruption charges, the most important "favor" that he supposedly provided to the security firms was quickly approving the prospectuses of new investment funds that they proposed (Nihon Keizai Shimbun, March 6, 1998, Evening Edition). 
Of course one might still wonder who ended up buying all the bonds that the companies issued? Figure 2 shows the distribution of bond purchases during the 1980 s. $^{27}$ Consistent with our account, direct individuals purchases were relatively small. Given the aforementioned impediments we do not find this surprising. Instead, it appears that various types of financial institutions (most notably insurance companies, commercial banks, and trust banks) were major purchasers, along with corporations and foreigners. ${ }^{28}$

We draw two further conclusions from this reading of the evidence. First, the Big Bang is likely to be more important in generating new options for savers than for borrowers, who by 1990 had already gained important alternatives to bank financing. Second, we believe that the historical record gives us little quantitative guidance as to how the households will respond to the Big Bang. It is clear that the banks will face significant new competition for funds, but there is too little evidence for us to make any strong predictions about which competitors will be the most threatening to the banks. Banks themselves are now allowed to sell investment trusts over their counters (since December 1998). This means that when we make our projections about the future size of the banking industry, our calculations will not rely on any specific assumptions about the future supply of funds to the industry. Instead as a plausibility check we will see what our forecasts imply about future changes in household portfolio decisions.

\subsection{Banks responses to the deregulation}

Our account of the savings behavior suggests that banks had a bit of windfall in that they were able to hold on to many their deposits despite the deregulation. But, the windfall was not big enough to offset the adverse fallout from deregulation and by the end of the 1990s the banks were in bad shape. While our story clearly gets the timing of events right, it may not correctly characterize the causation. For instance, one alternative explanation is that the Japanese banks are suffering now purely because of the poor performance of the overall Japanese economy in the 1990s. While we believe that macro conditions played an important role in shaping the fate of the industry, the question we care about is whether macro-factors were all that mattered. To assess this question we offer several pieces of evidence.

${ }^{27}$ These statistics are built up from flow of funds data that shows owners of domestically issued corporate bonds including convertibles and warrant bonds. The corporate bonds held by government financial institutions are excluded from the total to isolate the corporate bonds held by the private sector. Since the privatization of NTT in 1985 and JR in 1987 reclassified their bonds from public bonds to corporate bonds, the number includes NTT (JR) bonds that were issued before 1985 (1987) and have not been retired as of the end of 1990 in addition to the net purchases of corporate bonds.

${ }^{28}$ At the aggregate level corporate borrowing was rising since the large firms were tapping the bond markets and the smaller firms were increasing their bank borrowing. The savings that was funding this seems to have previously been going towards financing the government deficit which was falling in the late 1980 s. 
The starting point for our exploration is to see how the banks responded under the constraints of the prevailing regulations. As mentioned above, Japanese banks prior to the Big Bang were not really been able to move into the non-traditional areas of banking that many of the other global banks have pursued. To gauge the significance of these restrictions we compare the recent profitability and income sources for large U.S. and Japanese banks.

Table 11 shows data on the U.S banks. Unfortunately the regulatory reports from which these data are compiled do not directly provide information on revenue sources by line of business. As a crude measure of the income from non-traditional activities one can look at noninterest income. The table shows that non-interest income (relative to total income) has doubled since the early 1980s. This ratio has steadily climbed and most banking experts use these figures to argue that U.S. banks are successfully pushing into new lines of business.

The table also shows that U.S. bank profitability at the end of 1990s is at near record levels. The U.S. banks successfully rebounded from their very poor performance in the late 1980s. The initial recovery may have been partly due to luck, because the steep U.S. yield curve made it very easy for banks to make money by taking in deposits and investing them in government securities. However, even as the U.S. yield curve has flattened out, U.S. bank profits have remained high and during this time the percentage of non-interest income has continued to grow.

Table 12 shows similar data for large Japanese banks. Perhaps surprisingly they have about the same fraction of revenue coming from fee-based activities in the late 1990s as in the early 1980s. Although during the 1990s the banks have made a lower fraction of income from interest receipts, most of the decline has been due to an increase in capital gains realized by selling securities. ${ }^{29}$ Put differently, the total of interest income and "other" income has hardly changed in Japan. The table also shows how profitability (measured by either return on assets or return on equity) has deteriorated in the 1990s (even more so than the U.S. banks in the late 1980s.) Interestingly, the raw ROA levels (shown in the third to last column) are typically higher than the adjusted ROA levels which omit gains and losses from securities sales (and are shown in the last column) ${ }^{30}$ Thus, it appears that the banks have tried to mask some of the performance deterioration by recognizing capital gains on securities holdings.

While the Japanese banks have yet to expand much into non-traditional lines of business

29 This shows the practice referred to as fukumi keiei, hidden asset management. The Japanese banks and large firms often hold shares which were purchased long ago and therefore have unrealized capital gains. These firms sometimes try to smooth their eamings by selling the shares when operating profits are low. Table 12 shows this clearly. To protect their crossshareholding the sellers often buy-back the shares after recognizing the capital gains.

${ }^{30}$ The corrected return on assets is calculated as (Current Profits - Gains from Sales of Stocks and Other Securities + Losses from Sales of Stocks and Other Securities + Losses from Devaluation of Stock Holdings)/(Total Assets at the beginning of the period). 
they did re-organize their traditional lending patterns. Figure 3 shows the proportion of bank loans to small enterprises. ${ }^{31}$ The graph shows a dramatic increase in small business lending in the 1980s. As the banks started to lose their large customers to capital markets, they went after small firms. Most observers agree that previously the banks had not had close ties to many of these smaller borrowers. We return to this point below.

Figure 4 shows a second aspect of the banks' portfolio shift: increasing loans to the real estate industry. The proportion of loans to the real estate industry started to soar in the beginning of 1980s and soon surpassed the previous peak which had occurred during the Japanese Archipelago Rebuilding Boom of 1972-73. By the early 1990s, the proportion of loans to real estate industry by banks had doubled from its level in the early 1980 s.

A third change in the banks' behavior which has been emphasized by Peek and Rosengren (1997a, b) was a noticeable increase in foreign lending. As Peek and Rosengren explain, in some cases this lending was done through separately capitalized subsidiaries so that not all the loans would show up on the parent bank balance sheets. The Peek and Rosengren analysis shows that the foreign activity has dramatically slowed in the 1990 s.

One way to evaluate the portfolio shifts and performance is to see if they might have represented a natural response to the underlying economic conditions. After all, land prices were soaring in the late 1980 s so perhaps the shift into property-based lending was simply in keeping with past practices. To explore how much of the banks' performance might be attributable to basic economic conditions we ran several regressions.

The dependent variable for the regressions is the adjusted return on assets (AROA) for City Banks, which was shown in last column of table 12. As a robustness check we also tried the same regressions using the raw ROA series and found the same basic patterns. The adjusted ROA series is graphed in Figure 5. The figure shows that Japanese bank performance slowly declined from the mid-1950s through the 1980s and then sharply deteriorated in the 1990s.

To determine the role of deregulation on performance one would like to include a proxy for deregulation in a full-blown model of bank profitability. Unfortunately, we lack not only a compelling theoretical model that makes tight predictions about the exacts determinants of (adjusted) ROA, but also convincing proxies for the impact of deregulation. Given these limitations we take an indirect and admittedly ad hoc approach of looking only to see whether the dynamics for ROA changed following deregulation. Operationally our strategy amounts to checking whether there is a stable relation between ROA and standard macroeconomic variables

31 These data are taken from the Bank of Japan Economic Statistics Monthly. The small firms here are defined to be those that are not "large" according to Bank of Japan definition. Bank of Japan defines large firms to be those firms which have more than (yen) 100 million in equity and more than 300 regular employees. The definition of small firms here roughly corresponds to the small firms in the other tables in this paper. 
before and after 1983 (the date at which we argue the deregulation of the bond market began in earnest.) Thus, our modest goal is to provide evidence against a story that posits that macro factors can fully explain the banks' performance after the onset of deregulation.

We considered interest rates, land prices, stock prices and GDP growth to be the baseline set of macroeconomic variables that could be plausibly justified as determinants of ROA. Intuitively, these variables allow for monetary policy, collateral, and general economic conditions to drive bank performance. Because we had just under 30 years of data and did not have much guidance about how many lags to allow for in the regressions, we did almost no experimenting with other variables. The one exception was inflation which we measured using the GDP deflator and we found no independent effect of controlling for inflation.

Data limitations largely drove our choices of the specific proxies used in the regressions. In particular, the call rate (which measures the price of overnight credit between banks) is the only consistent interest rate series that is available from the 1950s onward. We take the difference between the nominal call rate and the current year's inflation to form our real call rate series. ${ }^{32}$

Similarly, the only consistent land price data come from a semi-annual survey conducted by the Japan Real Estate Research Institute. One survey covers all land prices nationwide and the other pertains to land prices in the six major metropolitan areas. The logarithmic differences in both series (again subtracting inflation) are graphed in Figure 6. This graph also shows the logarithmic difference of the TOPIX stock return index and inflation.

The figure shows three important things. First, the stock return series is much more volatile than either land price series. Large swings in stock prices routinely occurred throughout the period. Second, large changes in the relative price of land also had happened several times prior to the late $1980 \mathrm{~s}$. Furthermore, the land price changes were not always co-incident with the swings in stock prices. This is important because it means that we have some hope of identifying the econometric connection between land prices, stock prices, and bank profits. Finally, the figure also shows that the choice of which land price series to use could be potentially important. The late 1980 s land price run-up was concentrated in the major cities.

Two representative regression specifications among those we tried are shown in Table 13. One key issue is how to account for the long-term decline in profitability documented in Figure 5. In the first pair of regressions (which differ only in which land price is used) we include a time trend in addition to the macroeconomic variables. We draw two conclusions from these regressions. First, and not surprisingly, the time trend is the most important variable in the equation. Second, aside from stock prices which are of border-line importance, most of the macro variables appear to have no correlation with bank profitability.

32 Using instead the nominal call rate along with a separate inflation variable made no difference in what follows. 
The next two columns repeat the first specification except that a lagged dependent variable is added. The addition of the lagged dependent variable marginally improves the $R^{2}$ and wipes out the explanatory power of the time trend. The t-statistics of several of the macro variables rise, but the tests on the statistical significance of the sum of the coefficients, shown in the bottom of the table, continue to indicate that only the stock price coefficients are likely to be different from zero. This same pattern turned up in all of the variations that we tried that included lagged dependent variables. From this we conclude that prior to the mid-1980s there was at best a loose link between macro variables and bank profitability.

For both specifications we then checked how they fit after 1983. Figures 7 and 8 compare the actual values and fitted values for the regression specification including average land prices (the first and third regressions in the table). Importantly, the fitted values are one-step ahead forecasts, so the actual values of the right-hand variables are being used in forming these predictions. By taking this approach rather than going with a full dynamic simulation we are giving the prediction equation its best chance at explaining the post-deregulation events.

Our main conclusion from the figures is that the macro variables lead to an underprediction of banks ROA in the late-1980s and an over-prediction in the 1990s. This is most clearly seen in Figure 7 (which shows the results when there is no lagged dependent variable), but even in Figure 8, where the lagged dependent variable keeps the forecasts more closely on track, the 1988 and 1989 peaks are underestimated and the last few years of the sample are overestimated. This evidence leads us to doubt stories which argue that the formation of the bubble and its bursting can fully explain the banks' performance over the last fifteen years.

An alternative way to judge the stability of the models is to check for a structural break in the coefficients. Having only 15 years of data in the deregulated era led us to suspect that this type of test would have very little power. Nevertheless, the tests for structural breaks shown in the bottom half of the table indicate that none of the four equations is stable across the two regimes. In each case we can decisively reject the hypothesis of no change in the coefficients. In addition to being statistically different across the two periods, the differences also appear to be large in terms of their economic implications. For instance, many of the coefficients reverse their signs and the magnitude of the coefficient on lagged dependent variable also moves noticeably. Overall the tests for coefficient stability also confirm the inability of a set of stable macro correlations to explain the recent ROA data.

While we view this evidence as suggestive, we recognize that there are clear limitations to how hard we can lean on the lack of a well-fitting time series model for bank profitability. Our preferred interpretation of the Table 13 results is that the deregulation pushed the banks to alter their business practices so that their exposure to macroeconomic factors changed. But is also possible that we have simply failed to control for the correct macro factors and that the poor specification of our model is masking the truth.

We believe a stronger test of the importance of deregulation can be conducted by looking 
at cross-bank differences in performance. If our story emphasizing the role of deregulation is correct, then those banks which relied more heavily on loans to customers who obtained access to capital markets should have under-performed after deregulation. To test this hypothesis we check whether bank performance in the post-deregulation period is negatively correlated with the bank's pre-deregulation dependence on bank loans to traditional customers.

In this analysis we continue to date the start of the deregulation period as fiscal year 1983. Our performance measure is again return on assets corrected for the gains and losses from stock sales and the revaluation of stock holdings. To measure post-deregulation performance we use a time average of this variable. Time-averaging allows us to avoid being too dependent on correctly specifying the exact dates of the adjustment period. However, this could also mean that we are including observations when the response to deregulation had yet to begin or was already complete. To guard against this possibility we consider two different averaging intervals. We first use the average return for 1991-1997. We then also use the average for 1984-1997 so that we pick up both the boom in the late 1980s and the stagnation in the 1990s.

We consider two types of pre-deregulation bank characteristics that could influence the post-deregulation performance. One factor is a bank's reliance on income from traditional activities. We expect such banks to have fared (relatively) badly in the deregulated environment. As a proxy we use the proportion of current income coming from interest on loans. If this proportion is high it indicates that the bank's performance was relatively dependent on traditional activities at the onset of the reforms.

A second factor relates to the bank's customer base at the onset of deregulation. Ideally we would like to know which banks had many customers that were eligible to shift to bond financing. Unfortunately, data on the the external financing options for the bank customers are not available. We were able to collect information on the proportion of loans made to listed firms and the proportion of loans made to manufacturing firms. Given that the listed firms are typically large and are required to release audited information on their performance we think this is a fairly good proxy. We expect the banks that had a higher exposure to listed firms to have been at more risk of losing customers to the capital markets. We also know that size-based standards of the bond issuance rules made it easier for manufacturing firms to go to the capital markets in the 1980s. Thus, we also expect the banks that had more clients in manufacturing industry to have also been more likely to lose customers.

All the data except for the listed company loan shares come from Nikkei database on bank balance sheets and income statements. The data on the loan shares were collected from Keizai Chosakai's annual publication Kin'yu Kikan no Toyushi. The sample for the regressions includes 10 City Banks, 3 long-term credit banks, 6 trust banks, 64 regional banks, and 60 second-tier regional banks. ${ }^{33}$

33 Nippon Trust and Banking was excluded from the analysis because its return on assets is dramatically lower than all the other banks in the sample for the 1990s. Including this bank 
Table 14 shows the estimation results. Each column reports the coefficient estimates and their t-statistics for a different regression model. We draw several conclusions from this table. First, the proportion of interests on loans in the current income in 1983 is significantly negatively correlated with the post-deregulation performance. The correlation seems to be robust, as it turned up in all the specifications that we considered. Second, the proportion of loans to listed firms is also negatively correlated with post-deregulation performance, although the statistical significance of the coefficient is marginal when the average for whole post deregulation period (1984-1997) is used. ${ }^{34}$ Finally, the proportion of loans to manufacturing industry in 1983 is also significantly negatively correlated with the post-deregulation performance. We read these results as saying the firms that were more at risk because of the deregulation did seem to under-perform after 1983 .

Returning to the big picture, there are several ways to interpret the differences in the paths taken by the U.S. and Japanese banks. One interpretation is that the Japanese banks had a different vision of the future of the industry and pursued that vision. For instance, maybe the strong Japanese growth in the late 1980s led the banks to assess the profitability of various strategic options differently than U.S. banks (which were trying to recover from the bad loans they had extended in Latin America). We believe the regression evidence in the last two tables casts some doubt on this explanation, but perhaps a more complicated story involving incorrect future beliefs could explain the performance data. In this case, the fact the Japanese strategy may not have worked out is more of an accident than anything that was caused by the regulatory regime.

A second reading of the evidence is that the Japanese banks were constrained by the regulation from taking the path of the U.S. banks. Since many fee-generating lines of business were not available the banks chose to move into property related lending to small firms, perhaps knowing that this involved taking on more risk. ${ }^{35}$ This was not the only option for the banks.

noticeably changes the results, especially the ones concerning the effect of loans to listed firms. There are some other trust banks and long-term credit banks that experienced very low return on assets for the 1990s, but none of them individually influences the regression results in any significant way. When we ran the same set of regressions excluding all trust banks and long-term credit banks, we obtained qualitatively similar results.

${ }^{34}$ Ueda (1998) obtains a similar finding in his cross-bank regression analysis. His results show that banks with lower share of loans to small companies (hence higher share of loans to large firms) as of 1986 increased their loans to the real state industry more than other banks in the late 1980s. Furthermore, he finds that banks with a high share of loans to the real estate industry ended up having more bad loans.

35 There is no direct evidence that shows the loans to small firms and/or loans to real estate industry were more risky ex-ante than other types of loans. But, some studies find close associations between the amount of non-performing loans and the share of loans to real estate 
When large customers started to leave bank financing, the banks could have started buying government bonds and other securities instead of lending to new customers. We know now that this strategy looks relatively attractive and that few, if any, banks in Japan went this route. Regardless of what one decides about the rationality of banks responses, it seems clear that banks would never have chosen to search for new lines of business if their large customers had not shifted their financing patterns in response to the deregulation. In this sense, the regulatory mix seems to have mattered and one interpretation of our findings is that the poor performance was partially due to the deregulation.

For the purposes of looking ahead, it may not matter whether we can separate these two alternatives. At this point the Japanese banks remain among the largest in the world, yet they are now among the least profitable. Moreover, the approach of sticking to traditional banking and focusing on new, smaller customers has failed. As we showed in the last section, foreign firms and non-bank financial firms are moving quickly to compete with banks for funds. It seems reasonable to conclude that the Japanese banks are going to be pushed by all of these considerations to shift their strategy and become more like U.S. banks. But in moving forward the current conditions of the industry may place some constraints on which options are achievable. Thus, before making any forecasts about the future we briefly review the current conditions of the banks.

\section{The bad loans problem}

While it is widely recognized that Japanese banks are in bad shape, there appears to be little consensus on the magnitude of the problems. For instance, in early February 1999 a top Ministry of Finance official (Eisuke Sakakibara) was quoted as saying that the financial crisis would be over within a matter of weeks. At the time private sector analysts were arguing that conditions were deteriorating and that bold new steps were needed. Subsequently there have been rumors of official plans for another round of capital injections. Such conflicting opinions have been common for the last several years.

One problem plaguing the entire discussion is that there is no common standard for what people mean when they refer to "bad loans". One reason for this ambiguity is that the standards for determining which loans the banks identify as being at risk on their financial statements have varied over time. A second problem is that numbers from the bank balance sheets are only one of three types of estimates which are sometimes used to identify loans that are at risk. Unfortunately these three types of estimates are not even intended to measure the same thing and for each approach there are judgmental decisions that can swing the numbers considerably. As we now

industry or loans to small firms. For instance, Ueda (1998) finds banks with higher share of loans to real estate industry tend to have a significantly higher rate of non-performing loans. $\mathrm{He}$ also finds that banks with a higher share of loans to small firms tend to have a higher rate of non-performing loans, but this second result is not statistically significant. 
show, these considerations explain why, to a casual observer, there have been such divergent claims about the scope of the banking crisis in Japan. After having clarified the size of the problem we then discuss its implications for the future.

\subsection{Estimates based on data from banks financial statements}

Remarkably, Japanese banks did not disclose anything about the amount of their problem loans prior to 1993 . This lack of disclosure made it impossible to say very much about the condition of the banks. Since 1993 the banks have included footnotes on their financial statements that classify loans according to the health of the borrowers. The decisions for which loans should be identified in the footnotes have been made by the Japanese Bankers Association (Zenginkyo). Importantly, these voluntarily disclosed data are not supposed to take account of differences in the chances the different loans might be repaid (say because of differences in the collateral associated with the loans). For example, if a borrower files for bankruptcy all the loans made to the borrower are treated equivalently.

Table 15 shows these voluntarily disclosed data for 1993 through 1998 . The first half of the table shows information for major banks (city banks, trust banks, and long-term credit banks) and the second part shows the comparable number for all banks (major banks plus regional banks). From March 1993 to September 1995, the statistics covered only the loans to failed enterprises and the loans for which no payments had been made for a least 6 months. Thus, the figures did not include any restructured loans. Moreover, regional banks did not have to disclose (and many chose not to disclose) the loans with suspended payments. Under this reporting convention the amount of bad loans fluctuated around $¥ 12$ trillion roughly (3.5\% of total loans) for major banks and $¥ 13.5$ trillion (roughly $2.5 \%$ of total loans) for all banks.

For the major banks, intermittent data on loan write-offs are available for this period from the web site of the Financial Supervisory Agency. These data, shown in third column of the table, indicate that write-offs were quite low in these first couple of years of the banking crisis. The fourth and seventh columns of the Table show that during this period the banks were also slow in increasing the amount of funds set aside to cover the bad loans. Although provisioning was increasing, the loan loss reserves were never sufficient to cover the expected losses. For instance, as of September 1995, the loan loss reserves covered only 52\% of bad loans for major banks (and $60 \%$ for all banks). Analysts in the private sector repeatedly argued that the reported data grossly understated the true extent of the problems. For example, Ohara (1996) argued that as of March 1995 the bad loans for the major banks were more likely to be as large as $¥ 75$ trillion, once all the restructured loans and future liabilities of the affiliated non-banks were properly accounted for.

Starting with the accounting data released in March 1996 a couple of changes were made. First, the regional banks were now instructed to classify any loans with suspended payments as bad. More importantly, the bad loan definition was expanded to include loans for which the interest rates were cut to levels below the Bank of Japan discount rate at the time of the concession. These changes led to a sharp jump in the reported figures (with the totals rising to 
$¥ 20$ trillion for major banks and almost $¥ 27$ trillion for all banks). At the same time the amount of write-offs jumped.

The accounting data released in the following March included another change in definition, as loans to enterprises undergoing creditors-assisted restructuring were now included. Although the definition was expanded, the amount of bad loans declined slightly (to $¥ 18$ trillion for major banks and $¥ 24$ trillion for all banks). The amount of loans loss reserves also declined by $¥ 1$ trillion for major banks and by $¥ 1.2$ trillion for all banks. One contributing factor for the declines was an acceleration in the actual write-offs (which remove bad assets from the balance sheets). A second factor that probably helped was the brief recovery of Japanese economy in 1996.

In March 1998, the definition of bad loans was once again expanded. The new definition, which remains in place as of this writing, identifies bad loans (now called "risk management credits") as loans to failed enterprises, loans whose interest payments have been suspended for 3 months or more, and loans with concessions (which cover loans with reduced interest rates and loans to corporations under reorganization). This expansion of the definition and the deterioration in the economy in 1997 sharply increased the stock of bad loans. Thus, according to the most recent bank financial statements (September 1998), the official amount of bad loans stood at $¥ 22$ trillion for major banks and $¥ 30$ trillion for all banks. ${ }^{36}$ Overall, the bad loan numbers quoted on the bank financial statements still tend to be low since the banks need not identify loans to firms that are in trouble but where no restructuring or missed payments have yet been recorded.

\subsection{Estimates based on supervisory guidelines}

For supervisory purposes, the regulators have always been aware of this problem so the Bank of Japan and Ministry of Finance (and now the Financial Supervisory Authority (FSA)) have focused on the chances that a loan will be collected. This means that both the condition of the borrower and the quality of collateral are relevant. Accordingly, loans to the same borrower can be classified into different categories if they are secured by different collateral and hence offer different expected levels of repayment. The coverage of assets which are considered is also slightly broader than the voluntarily disclosed data since this assessment includes loan-like items such as securities loaned in addition to conventional loans.

Under this scheme, which is also used by U.S. regulators, loans are classified into four categories. Category 4 includes the loans that are non-collectable or of no-value. These are the unsecured portions of loans made to failed firms. Category 3 is the set of loans that have serious concerns in terms of their ultimate collection. These include loans to bankrupt (or nearly

${ }^{36}$ These numbers exclude the bad loans held by Hokkaido Takushoku Bank, Tokuyo City Bank, Kyoto Kyoei Bank, Naniwa Bank, Fukutoku Bank, and Midori Bank, which all either failed or merged with other banks in 1997. 
bankrupt) companies that are secured, but where the market value of collateral is well-below the book value. In practice these loans are expected to return little or nothing, unless the value of the collateral increases dramatically. The FSA describes Category 2 loans as "credits subject to specific risk management". These loans are not yet judged to be uncollectible but are deemed to require attention; the popular press sometimes refers to the Category 2 loans as being in the "gray zone." Category 2 loans are sometimes further classified to separate those loans that require "special attention" from the others. For example, the Financial Reconstruction Commission's guideline on provisioning for non-performing loans suggests two different provisioning ratios for these two sub-categories. Finally, Category 1 covers the remaining loans whose repayment is not supposed to be in any doubt.

Because of the large number of Category 2 loans (which are mostly excluded from the numbers shown on the bank financial statements), this classification scheme generally produces much larger estimates of problem loans. Starting in 1998, the government started to publish aggregate statistics on loans sorted according to these criteria. The banks' own assessments are reported in the top panel of Table 16. In December 1998 the FSA released its own estimates for the major banks (as of March 1998 based on their 1998 on-site examinations). These figures are shown in the bottom panel of the table. The FSA data suggest that the major banks in Japan had $¥ 57.4$ trillion of bad loans (or 14\% of total loans) as of March of 1998 .

Converting these figures into the expected cost of cleaning up the bank balance sheets requires two more assumptions. First, one has to decide whether the supervisors have correctly identified all the problem loans at the banks. It is generally agreed that the banks' self-reporting has been fairly optimistic. For example, when Nippon Credit Bank (NCB) was nationalized, the FSA announced that it had problem loans of more $¥ 3.7$ trillion; NCB’s own assessment put the losses at roughly $¥ 3.2$ trillion. The same kind of under-reporting was uncovered when the LongTerm Credit Bank (LTCB) was nationalized. Comparing the top and bottom panel in Table 16 shows that the FSA believed that the major banks had failed to identify roughly $¥ 7$ trillion of risky loans. In April 1999, the FSA issued new guidelines that included detailed instructions on how to classify loans.

A second problem is determining the fraction of the Category 2 and Category 3 loans that will ultimately be lost. A study by the Supervision Department of the Bank of Japan (1997) found that $17 \%$ of Category 2 loans and $75 \%$ of Category 3 loans identified in 1993 became uncollectable within three years. Although the sample size used in the BOJ study was very small, the numbers provide an upper bound on the recovery rates for Category 2 and Category 3 of $83 \%$ and $25 \%$ respectively. Assuming that the Category 4 loans are worthless, but that Category 2 loans do return $¥ 83$ against every $¥ 100$ is owed and that Category 3 loans return $¥ 25$ per $¥ 100$, the data in Table 16 imply that the total size of expected loss amounts to $¥ 14.78$ trillion (which is about $3 \%$ of GDP or $3.5 \%$ of total loans).

Some private sector analysts find this calculation very optimistic, because the calculation is based on the amount of problem loans reported by banks and FSA, and the figures in BOJ study 
overestimate the true recovery rates for problem loans. For example, Ohara (1998) estimates that the amount of bad loans at the major banks to be $¥ 73.4$ trillion as of March 1998. Assuming a $25 \%$ recovery rate for the risk management loans and $62.5 \%$ recovery rate for the remaining bad loans, she arrives at $¥ 35$ trillion (7\% of GDP) as the estimated loss. Fiorillo (1999a) estimated, as of February 1999, the size of loans for the major banks that will eventually be uncollectable to be $¥ 38$ trillion, or $7.6 \%$ of GDP. ${ }^{37}$ These estimates suggest (plausibly to us) that many more loans will have to be written-off than have been disposed of so far.

\subsection{Estimates based on the disclosures mandated by the Financial Reconstruction Act}

Since April 1999 another set of bad loan estimates have been floating around. Section 7 of the Financial Reconstruction Act requires each bank to report bad loans (as described below) to the Firancial Reconstruction Commission and to publish the data. Unfortunately, the FRA definition of bad loans falls in between the two previously described definitions. In particular, the FRA highlights loans to failed enterprises and defacto failed enterprises, loans to near bankrupt companies, loans whose interest payments have been suspended for more than three months, and loans with concessions. Essentially this means that the FRA definition includes the Category 3 and 4 loans according to the supervisory definition, but not all of the Category 2 loans. Instead the FRA definition focuses only on any remaining loans that would be counted in the banks' voluntarily disclosed data.

Given this reporting convention the FRA estimates should be expected to lie in between the two prior sets of estimates. In the first round of disclosure, which covers the conditions as of March 1999, the amount of bad loans for the 15 major banks (and thus excluding LTCB and $\mathrm{NCB}$ ) is reported to be about $¥ 20$ trillion. This is about $¥ 6$ trillion larger than the voluntarily disclosed data but far below the supervisory estimates (Fiorillo (1999b)). For a further discussion of how the various sets of estimates compare see Iwahara, Okina, Kanemoto, and Narisawa (1999).

Overall, we conclude that there are three key considerations that must be kept in mind when evaluating different estimates of the size of the bad loan problem. First, and most importantly, one must check whether the data are based on assessments of the collectability of loans or are taken from the bank financial statements. Assuming that most people will want the collection based estimates, it is necessary to determine whether the data have been self-reported by the banks or are based on supervisors' (or private sector analysts') estimates. Finally, it is imperative to be clear about what assumptions are being used regarding the fraction of the gray zone loans that will be collected.

To help put the Japanese bad loan problem in perspective, Table 17 shows the size of banking crises in other developed countries over the last two decades -- see Corbett (1999b) for a

${ }^{37}$ Private sector analysts also point out that there are also probably large losses in financial institutions besides the banks. 
more comprehensive comparison. Clearly the Japanese crisis is much larger than the U.S. savings and loan crisis and thus a full bailout would require significantly more resources than were deployed in the U.S. rescue. Discussions of what to do about a bailout are further clouded by the fact that the government is already running a large deficit (e.g. estimated to be more than $6 \%$ of GDP by the IMF (1998b).) On top of this, Japan faces a significant upcoming social security problem. This has led the government to try to rein in the deficits. For instance, the Fiscal Structural Reform Act passed in November 1997 required the government to bring the deficit below 3 percent of GDP by fiscal year 2003. The weakness of the economy led the government to first push back the goal by two years in May 1998 and then eventually suspend the Act completely in December 1998. There is still strong sentiment, however, within the government for trying to begin cutting the deficit as soon as possible.

We draw two conclusions from this assessment. First, the fiscal concerns suggest it is important to focus on the amount of funds that would be needed to keep a large enough banking sector in place to serve borrowers once the crisis is over and the deregulation has taken hold. By looking ahead, one can try to determine the minimum amount of public money that will be needed. We can then compare the minimum estimates to the various proposals that have been made.

Second, in assessing the options that the banks have in developing new strategies it is important to account for their weak capital positions. The flip-side to the problems documented in Tables 15 and 16 is that the Japanese banks have very low levels of capital and are likely to have trouble raising much money in the capital markets in the short-run. For instance, the Moody's rating agency gives most of the major Japanese banks a financial strength rating of $E$ or E+ (the two lowest ratings on their scale). Such banks are expected to "require periodic outside support". As a consequence of these circumstances the banks are unlikely to be able to purchase other large firms in order to acquire expertise. Similarly, bankruptcy seems like a real risk that would become more eminent if they were to undertake any large investments that have long payback periods. With this in mind we sketch one scenario for the future of the Japanese banking sector.

\section{Quantifying the impending shrinkage of the Japanese banking sector}

The evidence presented in Section 3 suggests that large manufacturing Japanese companies have already almost reduced their reliance on banks to about the level of bank dependence observed in the U.S. If our conjecture that other firms will soon be following this lead is correct, it is natural to ask what that might imply for the future of Japanese banks. The purpose of this section of the paper is to quantitatively explore this question.

\subsection{Maintained assumptions and caveats}

Before diving into the calculation it is important to recognize several caveats about the 
nature of the exercise. First, our approach should be thought of as only calibrating the eventual size of a possible reduction in loan demand. We will explore several different assumptions about potential shifts, but all of our scenarios will take years to play out, so that the numbers that follow can at best be thought of as medium-run forecasts. We discuss the timing issues further in the next section.

Second, we are implicitly assuming that loan demand will drive the size of banks. Although we believe this is the most reasonable assumption to make, it could fail for a variety of reasons. For instance, depositors may continue to stuff their money into the banks even after all the Big Bang reforms are complete. For the most part we have also ignored the presence of the huge Japanese postal savings system (PSS). But there is a continuing debate about whether the PSS should be reformed, even possibly privatized. It is easy to imagine PSS reforms that wind up pushing large savings flows back towards the banks. We will briefly discuss the plausibility of the size of the implied adjustment in deposits after we present our findings.

Another risk of basing our forecasts on loan demand is the possibility that the banks could shed loans but pick up enough new lines of business so that they would not have to shrink. ${ }^{38}$ Given that the Japanese banks currently have very little expertise outside of traditional banking and limited capital to buy such expertise this scenario may seem unlikely right now. However, if some of these banks end up being sold to foreign financial services firms, this possibility becomes much more realistic. In view of the rapidly changing competitive landscape of the Japanese financial services industry, we view this as a genuine possibility.

A third complication is that because we focus on the bank debt to assets ratio one must take a stand on what will happen the growth of corporate assets in order to draw any conclusions about the level of bank lending. Put differently, if corporate assets are growing then forecasts of a declining bank debt to asset ratio need not imply that the level of bank loans will fall. However, there are several pieces of evidence which suggest that an assumption of zero growth of corporate assets is a reasonable forecast for Japanese firms over the medium-run.

One consideration is the recent evidence on asset growth. The Hojin Kigyo Tokei data suggest that total assets for all industries grew only at $1.7 \%$ a year from 1993 to 1998 . Since new firms are added to the survey each year, the number in fact overstates the true growth rate of corporate assets. If this trend were to continue, then asset growth would be sufficiently low to not matter much for our purposes.

Another factor, which has been emphasized by the Japan Economic Research Center (1997), is that Japanese corporations are expected to begin reducing their financial assets (especially low return liquid assets) as their financial management skills improve. The dwindling practice of banks requiring compensating balances, together with the winding-down of cross-

${ }^{38}$ There are also factors that push in the other direction. For instance, these calculations ignore the possibility of foreign lenders taking away business from the Japanese banks. 
shareholdings will further contribute to the reduction of financial assets. Thus, even if a business cycle recovery leads Japanese corporations start increasing their fixed assets, declining financial assets will be a significant offsetting factor. For these reasons we believe that a reasonable benchmark is to translate any forecasted declines in the bank debt to asset ratio into one-for-one declines in bank lending.

Finally, we also recognize that this whole exercise ignores the potential general equilibrium feedbacks that could occur with large changes in intermediation. Partly this is out of necessity, since building a full model of the financial sector is not yet possible. However, this strategy can be partially justified if we maintain that the economic role of banks is tied to loan generation, particularly to smaller firms, and that for most other activities banks are redundant. Under this view, if the banks were to hold onto customers that might otherwise go to the capital market, the banks would have to match the capital market rates. As these rates are increasingly determined by global forces, our assumption does not seem too unreasonable.

Keeping in mind all these caveats we now explore what would happen if all Japanese corporations followed the lead of the large manufacturing firms that have already moved towards U.S. levels of bank dependence. ${ }^{39}$ Since we want to consider several scenarios, we start by describing and defending the two basic assumptions that are common to all projections. After discussing these premises we outline the different scenarios that we consider.

The first key assumption is that loan demand for large and small firms can be aggregated within sectors. Thus, for each sector we treat all large firms and all small firms identically. We do not necessarily treat large firms and small firms symmetrically within or across sectors. Our main justification for this approach is the evidence in Table 7 regarding the relative stability of the bank borrowing patterns exhibited by the U.S. firms.

Our second key assumptions involve the choice of sectors to be analyzed. The only really reliable data that we have for the U.S. pertains to manufacturing. We also have some information for large firms in the wholesale and retail trade sectors. In all of our projections we separately model these three sectors, in some cases making finer assumptions about what is happening within manufacturing. Unfortunately, this means that we have no U.S. data to guide us for other industries. Given this absence of data we aggregate the remaining Japanese industries into an "other" category.

\subsection{Implications of U.S. borrowing patterns for Japanese loan demand}

There are three basic inputs into the forecasts that we report. The first piece of information is 1998 total amounts of borrowing done by large and small firms across our four sectors of the Japanese economy. These numbers come from the Hojin Kigyo Tokei and we follow the convention from Table 5 of defining large firms to have a book value of capital above

39 The whole exercise is very much in the spirit of Rajan and Zingales (1998). 
$¥ 1$ billion. The second element in the calculation are the initial observed levels of bank dependence for the large and small firms in the different sectors. These numbers can also be directly computed using the unpublished data we obtained.

Table 18 shows the 1998 distribution of bank borrowing and bank dependence for Japanese firms. Table 5 had already shown the noticeable differences in large and small firm bank dependence across sectors. We draw three further conclusions from Table 18. First, the "other category" covers over half of the bank borrowing done by firms in the sample. Since we have no representative data for these firms in U.S. this means that a significant portion of our forecast will be based purely on imputations for what might happen to this large, un-modeled segment of borrowers.

Second, the table shows that Japanese banks are already primarily serving small borrowers. Adding up loans made to small firms across all four sectors reveals that small borrowers receive about $64 \%$ of the bank credit tracked in the Hojin Kigyo Tokei. One check on the plausibility of our forecasts will be to see if they imply reasonable splits between the aggregate amount of large and small firm borrowing.

Lastly, the table also indirectly shows the comprehensive coverage of the Hojin Kigyo Tokei. According to balance sheet information for all banks, total lending should be about $¥ 450$ trillion as of March $1998 .{ }^{40}$ The coverage in our sample is $¥ 445$ trillion. The close match actually masks two differences. One difference is that the survey includes borrowing from financial institutions such as credit unions that are not counted as major banks. However, the survey also excludes borrowing done by truly tiny firms. It appears these two factors largely cancel.

The final ingredient needed for our forecasts is the assumed level of bank dependence that will prevail in the new steady state. Wherever possible we try to pin down these figures using the U.S. experience. Based on the QFR data from Table 7, we can get benchmarks for large and small manufacturing firms, large retail firms and large wholesale firms. In fact for the manufacturing sector we can do better and get two-digit level data for the 14 industries. However, we have no solid data for the borrowing by U.S. firms in the "other industries" and therefore try several very different ways of calibrating the changes for these firms.

Since each hypothesized steady state requires eight assumptions about the bank debt to asset ratios (two types of firms in four sectors) there are endless simulation possibilities. To simplify the reporting, we hone in on three different variations that we believe should bound the implied adjustments. Each of these variations amounts to setting a switch that pins down two or more of the eight bank-debt to asset ratios.

${ }^{40}$ This figure excludes overdrafts. We believe that excluding overdrafts makes sense because such commitment lending is unlikely to be affected by the Big Bang. See Kashyap, Rajan and Stein (1999) for theoretical support for this argument and empirical evidence showing that even in the U.S. the commitment business is dominated by banks. 
The first set of alternatives involve differing assumptions about the behavior of Japanese manufacturing firms. Our simplest assumption is that the large and small firms bank dependence in Japan converge to the same levels that hold for the typical large and small manufacturing firms in the U.S. We call this case the simple manufacturing assumption. As discussed earlier, this assumption ignores the differences in industrial composition between the two countries. Therefore, we repeat the calculations assuming instead that large and small Japanese firms' bank dependence converges on an industry-by-industry basis to the U.S. levels. Here we have data for 14 industries (shown in Tables 8 and 9) and we form a fifteenth category for the remaining firms. Although we conduct the calculations at the industry level the results are aggregated back to the total manufacturing level for reporting purposes. We denote this second case as the industryadjusted manufacturing assumption.

A second pair of assumptions relate to the treatment of small firms in the wholesale and retail sectors. Although the QFR gives us some data on U.S. borrowing propensities for large firms there are no QFR data for small firms in these sectors. The only available data that we know of describing small firm borrowing patterns in the U.S. is the 1993 National Survey of Small Business Finances (NSSBF). This survey, conducted in 1994-95 for the Board of Govemors of the Federal Reserve System and the U.S. Small Business Administration, covers a nationally representative sample of very small businesses. ${ }^{41}$

Petersen and Rajan (1994) have analyzed these data and were kind enough to provide us with some simple tabulations of the ratio of bank debt to assets for these firms. These tabulations suggest that for the NSSBF the total debt ratio was between 0.18 to 0.24 for the sector groupings that we are analyzing (on an asset-weighted basis). We also learned that banks supply about half of all loans to these firms. However, there are two factors that make us hesitant to completely rely on these numbers in our simulations. One concern is that the firms in the NSSBF are very small. For instance, the top decile of firms in this sample includes firms with as little as $\$ 2.3$ million in assets. The "small" Japanese firms that we are studying appear to be about ten times bigger in terms of average assets.

Secondly, we know that bank borrowing becomes more important once firms grow. For instance, within the NSSBF sample, both the fraction of firms with any debt and the fraction of firms debt owed to banks rise with firm size. Thus, we suspect that U.S. firms which would be comparable in size to our sample of Japanese firms would be more bank-dependent in their financing than are the NSSBF firms. Nevertheless, it seems to us unlikely that this growth effect would be strong to push the banks debt to assets ratio much beyond the $35 \%$ (which is the upper end of the range for the total debt to asset ratio in the NSSBF).

${ }^{41}$ The target population is all for-profit, non-financial, non-farm business enterprises that had fewer than 500 employees and were in operation as of year-end 1992. The public data set contains 4637 firms, and describes all the loans each firm has as of year-end 1992, as well as the institutions that these loans came from. 
With these numbers as a reference we consider two different scenarios for the small trade firms. The first approach plays off of the small firm to large firm borrowing ratio that is observed in U.S. manufacturing. We apply this ratio to the level of the QFR data for large firms in each sector to get a target level of small firms in each sector. We describe this assumption as identifying small trade firms' bank dependence using U.S. manufacturing data. Given the data in tables 18 and 7 we can see that this will imply bank debt to asset ratios of about 0.23 and 0.32 for small retail and whole firms respectively.

Are these numbers reasonable? In the NSSBF sample these figures are 0.24 and 0.20 , respectively. Using the figures from Table 7 this suggests that the ratio of the NSSBF levels of bank dependence to the levels found for large retailers and wholesalers are in line with the approximate 2-1 ratio found in U.S. manufacturing. Thus, we believe that unless the NSSBF data significantly understates small firms bank dependence, assuming the small and large firms differences are about the same (in ratio terms) across sectors seems plausible.

Our second approach exploits the fact that we can observe both small and large firms borrowing patterns for the Japanese trade firms. In this case we get the steady-state target level of small firm borrowing for wholesalers by multiplying the ratio of small firm to large firm bank dependence of wholesalers in Japan by the level of bank dependence for large U.S. wholesalers. In essence this assumes that both large and small Japanese wholesalers will adjust by the same percentage. We carry out the same calculations for retailers, and describe this assumption as identifying small trade firms' bank dependence using existing Japanese borrowing patterns. Using these assumptions, the target levels of bank dependence are 0.20 and 0.18 for small retail and wholesale firms respectively. These targets are both below the levels found in the NSSBF and thus are likely to lead us to overstate the decline in bank dependence.

Our third and last set of cases involve the assumptions about the levels of bank dependence for the other industries such as transportation, communications, services, and construction where we have absolutely no QFR data. Based on the Japanese data shown in Table 18, we can see that as of 1998 these firms are more bank dependent than the wholesale and retail firms. However, these firms also have more of their bank borrowing being done by large firms than is the case for either wholesalers or retailers. Considering both these factors, we use the average proportional adjustment done by the wholesale and retail trade firms to come up with the required adjustment for the large and small firms in the other category. More specifically, we assume that the ratio of the target level to the current level of bank dependence for large (small) "other" firms is equal to the weighted average of the target to current ratio for large (small) firms in wholesale and retail trade industries. In the NSSBF data the level of bank dependence for other sector firms is close to the level of bank dependence for trade firms. Thus, for small firms this assumption (which does not force the levels to converge) seems conservative.

Given the amount of guesswork involved constructing this benchmark, we consider a second refinement in which we assume these other firms only adjust half as much as the similarlysized average trade firm. We describe this refinement as "halfway convergence" to distinguish 
from the first case above, which is called "full convergence." This "halfway convergence" case is an attempt to trade off our ignorance about how the large firms in this sector are financed with the presumption that capital market financing is likely to displace at least some bank lending.

We summarize the pairs of alternatives and introduce some short-hand notation for describing them in Table 19. Since the three alternatives are mutually exclusive we have eight total cases to consider. By comparing the scenarios where two of the three factors are held constant, we will be able to take derivatives to determine which of the convergence assumptions are most powerful. Below as a sensitivity check we also explore what happens if we do not assume that the large Japanese firms in wholesale and retail trade go all the way to the levels seen in the U.S.

Table 20 compares the eight alternative steady states for future loan demand to the current levels of borrowing by Japanese firms. We draw five main conclusions from the calculations. First and most importantly, under all the scenarios we explore, the U.S. benchmark implies a large impending decline in loan demand by Japanese firms. The smallest hypothesized contraction suggests a decline of more than $25 \%$ in bank loan demand. Even recognizing that these calculations refer to medium-term adjustments, we find the implied drops to be quite large. We discuss the transitional implications of this kind of shift in the concluding section.

Second, the forecasts all seem reasonable in terms of the implications for the steady state customer mix of the Japanese banks. The various scenarios all imply that small firms will account for between $62 \%$ and $72 \%$ of bank borrowing. These ranges seem to be plausible and since this ratio was endogenously calculated, we find this to be a reassuring check on the methodology and our assumptions.

The other three conclusions concern which of the different assumptions appear to be quantitatively important. The different treatment for manufacturing firms does not appear to matter much. Holding constant our other assumptions about the non-manufacturing firms, the decision to account for inter-industry variation in manufacturing borrowing patterns only changes the implied level of borrowing by about $0.1 \%$. The implied percentages of aggregate borrowing by small firms also do not move very much across these two assumptions.

In contrast, the other two assumptions make a big difference. These two assumptions interact since the target levels assumed for the small trade firms also help determine the target level of borrowing by small firms in the other category. Whether or not the "other" firms adjust all the way or just half way accounts for at least an 11 percentage point difference in the total project level of borrowing. Similarly, the two alternatives for the target levels of borrowing by small trade firms lead to an estimated difference of at least seven percentage points. As predicted, the benchmark based on the patterns in U.S. manufacturing produce smaller declines. Overall, the large size of these effects suggest that further work to narrow the uncertainty over which assumptions to rely upon is needed. 


\subsection{Plausibility checks for the implied shrinkage in the Japanese banking sector}

Given the large magnitudes of the projected decline in lending, one would like to see if there are other implications of this forecast that can be verified or alternative assumptions might overturn the prediction. We briefly describe three alternative plausibility checks that we have conducted.

Our first test is to see whether the sectoral implications for drops in loan demand are credible. Implicit in all the estimates shown in Table 20 is the assumption that firms in the trade sector fully converge to the levels of bank dependence in the U.S. Given the sizable existing gaps between large firms' bank dependence in the two countries documented in tables 5 and 7 this is a fairly strong assumption. Indeed, one might also question whether it is prudent to forecast that bank dependence among small manufacturing firms will converge.

To address these concerns we conducted another set of simulations that presume far less convergence than is built into our baseline scenario. In these simulations, we maintained that only large manufacturing firms would fully convergence to the same level of bank dependence. For all the remaining firms, Japanese firms were posited to move halfway towards the level of bank dependence that is observed in the U.S. We view these assumptions as being extremely conservative, and yet they still imply reductions in the bank debt to asset ratio of between $22 \%$ and $29 \%$ (depending on which of the various assumptions are used to pin down the target levels for the small trade and other firms).

From Table 18 one can see why a reduction of at least $20 \%$ seems inevitable. The key observation is that the 1998 borrowing patterns in Japan do not involve much bank credit going to large trade firms. So varying their bank dependence does not have much aggregate effect. But, about $42 \%$ of total bank lending is going to small firms in retail trade and other industries which have very high bank debt to asset ratios. Even modest adjustments by these firms, combined with a continued decline in bank borrowing by the numerous large manufacturing firms will generate a large decline in the bank debt to asset ratio.

A second plausibility check involves exploring what our forecast will imply for depositors. The evidence in section 3 suggested that in the past Japanese individuals have not abandoned the banks. One obvious question is whether our medium-term forecast implies incredible shifts in the behavior of depositors.

Figure 9 shows how (as of June, 1998) Japanese households allocated their $¥ 1,200$ trillion of financial assets. As we pointed out in Table 10, the Japanese households historically have heavily relied on deposits. Figure 9 indicates that currently $59 \%$ of household financial assets are in cash and deposits (including postal savings). A 30\% rate of shrinkage for bank loans translates into $¥ 133$ trillion reduction in bank loans (using 1998 2nd quarter data from Quarterly Report of Incorporated Enterprise Statistics). If we consider an extreme case, then deposits at these institutions also must fall by $30 \%$. This would reduce the total amount of cash and deposits 
(including postal savings) by $18 \%$, and its proportion in total financial wealth would fall to $48 \%$. In terms of the deposit to GDP ratio, we would also expect a decline of $18 \%$, which would reduce the ratio to 0.50 .

Looking at Table 10, we note that a deposit to GDP ratio of 0.50 is still higher than many industrialized countries. Starting from a level of 0.62 in 1997, this type of decline seems reasonable if we are talking about a seven to ten year horizon. The prediction that the proportion of cash and deposits in the household financial assets will decline to $48 \%$ is also plausible - this would still leave Japan with more deposits relative to wealth than other G7 country. Similarly, the Japan Economic Research Center (JERC) (1997) forecast that the proportion of cash and deposits in household financial assets will decline to $45 \%$ by 2010 and to $35 \%$ by 2020 .

Their forecast is premised on a massive shift of household assets from deposits to investment trusts, which they see growing from their current level of $2.3 \%$ to $9.1 \%$ by 2010 and to $20 \%$ by 2020 . In our scenario, if we assume all the decline in household deposits is matched by an increase in investment trusts, then we would expect the share of investment trusts increase to $13 \%$. Thus, our scenario also implies a huge boom for investment trusts.

There are many other analysts who forecast similar gains for investment trusts. For instance, Naito (1999) argues that because of a 1998 change in regulation, investment trusts are the most appealing financial product for households. The 1998 change allowed "company-based" investment trusts, which are closer to mutual funds in the U.S. than "contract-based" investment trusts, which has existed in Japan throughout the post-war period. Perhaps more importantly, the change allowed banks and insurance companies to sell investment trusts at their counters starting in December 1998. The amount of investment trusts purchased through banks or insurance companies had jumped to 303 billion yen by the end of January 1999 (Naito 1999, p.23). Although this is only $1 \%$ of the total value of investment trusts outstanding, it may be the beginning of a much larger portfolio shift by Japanese households. Given these considerations we do not find the implications of forecasts for bank deposits to be implausible.

Finally, we ask whether there are any methods one might use to estimate the future size of the banking sector that do not rely on assumptions about loan demand. Moody's (1999) offers a prediction based on profitability. They argue that a reasonable benchmark is to assume that Japanese banks will need to have the same ratio of tangible equity to assets as is found in other countries. ${ }^{42}$ They estimate that as of March 1999 Japanese banks have a tangible equity to asset ratio of $4.2 \%$, while large U.S. banks have a ratio of around $6.5 \%$ Assuming that equity issuance is not possible this leads Moody’s to forecast a reduction of over $¥ 100$ trillion in risk-weighted

42 The ratio they consider is Tier 1 capital (as defined by the Basle banking accord) minus state capital minus preferred securities divided by risk-weighted assets (see Moody's (1999), page 24 for details). 
assets to reach the U.S. level. ${ }^{43}$ As they note in the short-run this can partially be done by securitizing loans. But ultimately this seems like another way to arrive at the conclusion that a large contraction in the sector is needed.

An alternative prediction is available from a long-term forecast published by the Japan Economic Research Center (1997). The JERC forecasts the levels of financial assets and liabilities for each sector identified by Bank of Japan flow of funds statistics. Although they do not reveal detailed assumptions behind their forecasts, some of their predictions are based on assumptions very similar to ours. For instance, they assume the Japanese corporate financing patterns will move toward the U.S. model. Looking at their forecasts for the market values of financial assets and liabilities, we find that their prediction implies that the bank debt to assets ratio for the corporate sector will decline from 0.4461 in 1995 to 0.2395 by 2020 . Since they use the market values, the numbers are not directly comparable to our numbers, but the magnitude of the decline in the bank debt ratio ( $46 \%$ in 25 years) is as large as what our analysis implies.

Because they assume rather high rate of growth in assets (3.3\% per year for 25 years), they forecast the level of bank loans to rise from 555 trillion yen in 1995 to 672 trillion yen in $2020(0.76 \%$ growth per year). With a more reasonable growth rate of assets, their prediction would also imply the shrinkage in the absolute level of loans. For example, if the assets grow only at $1.5 \%$ per year, then bank loans would be project to decline to 432 trillion yen by 2020 , a $22 \%$ drop.

\section{Conclusions}

We have argued that the disequilibrium created by the gradual and lopsided deregulation in the Japanese financial system played an important role in the current banking crisis. The deregulation allowed large bank customers to quickly shift from bank financing to capital market funding. Mean while the deregulation did relatively little for savers, so banks continued to attract deposits. However, the deregulation of bank powers also was slow and gradual. This meant that if the banks were to keep lending they would need to seek out new customers. The banks did take on many new small customers. They also expanded their real estate lending. Ultimately these bets proved to be unprofitable.

In support of this story, we present a variety of evidence. One finding is that the banks' performance was worse in the 1990s than would be predicted just on the basis of macroeconomic conditions. Similarly, across banks, we find that the banks that were most at risk for losing customers to the capital markets performed worse than others. Both these results suggest the importance of the deregulation. We also document that large Japanese firms (particularly in manufacturing) are now almost as independent of bank financing as comparable U.S. firms.

${ }^{43}$ Loans are roughly $¥ 450$ trillion, so if the reduction was fully done by cutting loans this would imply a $22.2 \%$ decline. 
We argue that once the Big Bang financial deregulation is complete, even the relatively small firms will start following the route already taken by the large firms by cutting their dependence on bank loans. By assuming other firms' financing patterns will also converge to the U.S. patterns, we calculated how much Japanese banking sector must shrink in the steady state. Uniformly the scenarios that we examined imply a massive contraction in the size of the traditional banking business in Japan.

While there are many reasons why one might quibble with the details of the calculations in Table 20. we think they at least provide a reasonable benchmark. To overturn the basic thrust of the calculations, one must argue that the basic U.S. benchmark is inappropriate. We believe we have made a compelling case that for the large firms, the benchmark is reasonable. For the small firms, we concede that there is much more guess work involved. But, even if we take our most conservative scenario where full convergence in bank dependence is only assumed for large manufacturing firms, and all remaining firms move halfway toward the U.S. levels, we still end up projecting more than a $20 \%$ decline in loan demand. This forecast is in the small ballpark that Moody's (1999) arrives at by making quite different assumptions.

What would a $20 \%$ decline imply for the configuration of the banking sector? There are many possible ways that this could shake out. However, given the current debate over how much public money should be used to prop up the banks, one natural question to ask is how many weak banks would have to completely exit to eliminate the excess capacity in the industry? To pursue this, we took the ranking of 142 Japanese banks as of September 1998 put forward in the March 1999 issue of Kin' $y u$ Business and calculated the share of loans for each bank. ${ }^{44}$ This allows us to examine how many banks must exit so that the cumulative shrinkage in loans is sufficient to bring the system to its new steady state.

We find that a $20 \%$ reduction in lending requires a complete exit of the lowest rated 45

44 They rank ordinary banks (city banks and regional banks) and trust banks separately by looking at size (measured by the average amount of funds), profitability (measured by business profits to asset ratio and interest margin), efficiency (measured by expense ratio and interest income per employee), and solvency (measured by capital ratio, non-performing loan ratio, provision ratio for non-performing loans, and market-to-book ratio of securities holding). In order to combine two separate rankings, we re-ranked city banks, trust banks, and a long-term credit bank (Industrial Bank of Japan) using 8 of 9 indicators used by Kin'yu Business. The last indicator (market-to-book ratio of securities holding) was not easily available. We established the rankings of trust banks and IBJ in the list of ordinary banks by comparing them to city banks included in the list. For example, we rank Sumitomo Trust after DKB (ranked 12 in Kin 'yu Business) and before Fuji (ranked 28). Since Sumitomo Trust is located more or less right in between DKB and Fuji according to the indicators we are looking at, we place Sumitomo Trust between Kyoto (ranked 20) and Yamaguchi (ranked 21). Finally, we added the two banks that were nationalized in late 1998, Long-Term Credit Bank of Japan and Nippon Credit Bank, at the bottom of the ranking. 
banks of a total of 142 banks. These include Long-Term Credit Bank (LTCB) and Nippon Credit Bank (NCB), which are nationalized in late 1998 and the regional banks that were put into receivership in the first half of 1999 . Perhaps more importantly, this set of 45 banks would include 3 of the 15 banks (Daiwa, Tokai, and Chuo Trust) that have recently received a government capital injection. If we consider a $30 \%$ shrinkage, which is closer to the average of the Table 20 estimates, the number of weak banks that would have to be eliminated jumps to 69 , including three more (Yokohama, Asahi, and Toyo Trust) of the 15 banks which just received government money. Even if the relatively healthy banks can somehow be convinced to cut back on some of their lending, it is hard to escape the conclusion that any transition looks like it will involve the exit of a number of major banks.

Because any assessment of banks' health is somewhat subjective we also looked at the Moody's Investor Service (1999) rankings. They estimate the "financial strength" of 51 Japanese banks. Their ratings range from B (Shizuoka Bank) to E (10 banks including LTCB and NCB). Moody's assessment differs from the Kin'yu Business ranking in that it focuses on solvency and looks at not only obligations of parent but also those of supported subsidiaries. Nonetheless, both Kin'yu Business ranking and Moody's rating identify very similar sets of "weak" banks. For example, 10 of the 45 lowest ranked banks in Kin'yu Business are rated by Moody's, and 8 of them have the lowest $(\mathrm{E})$ rating and the other 2 the next lowest rating $(\mathrm{E}+)$. Among Kin' $y u$ Business's 69 worst banks, 15 of them are rated by Moody's, and 9 of them have $E$ and the other 6 have E+. Thus, the weakest banks in Kin'yu Business ranking are also rated very low by Moody's.

Given this overlap it is therefore not surprising that if we base our exit forecasts on the Moody's data we get a very similar picture. If we assume that 10 banks with $\mathrm{E}$ ratings will disappear, their cumulative loans amount to $11.5 \%$ of total loans in the banking sector. Three of 15 banks (Daiwa, Chuo Trust, and Mitsui Trust) that have just received the capital injection are included in this group. If all the banks with $E$ ratings and $E+$ ratings were to exit, their cumulative loans would be $49 \%$ of total loans, suggesting a much bigger contraction than we expect. However, included in the set of $\mathrm{E}$ and $\mathrm{E}+$ banks are 13 of the 15 banks that received government money, so it still looks like a non-trivial fraction of these banks may be redundant.

How long will it take for such a shift in the Japanese banking to be completed? The speed of adjustment will primarily depend on three factors: how fast corporations adjust their financing, how fast households shift their funds out of bank deposits, and how fast the banking industry is reorganized. The previous experience suggests that the adjustment by corporate borrowers will be fairly quick. Although the restrictions on corporate financing options were only gradually loosened, many firms adjusted quickly and most completed their adjustments in less than 10 years. The deregulation of the remaining restrictions on corporate financing will be rapid. Thus, we expect the adjustment on the corporate finance side to be complete well within 10 years.

How fast will the households move? Because the most significant elements of the liberalization of savers' options have started only very recently, this question is much harder to 
answer. As we saw above, the dependence on deposits by Japanese households starts from such a high level that only a modest change towards the patterns observed in other OECD economies would be sufficient to support our forecast. We believe that a modest shift can take place in ten years, but there is a considerable amount of uncertainty in this conjecture.

Finally, the shrinkage of bank loans will imply a substantial exit in the banking industry unless Japanese banks shift away from traditional banking business very aggressively. The speed of such a reorganization obviously depends on the government's policy stance toward bank failures. As we saw in section 4 , the Japanese government seems to be finally getting ready to begin facing the bad loans problem. The next step will require more closures of insolvent banks. If the current tough stance of the FSA and the FRC continues, the days of the convoy system of rescues will be over.

Nevertheless, once the restructuring begins in earnest we imagine that it will take several years for the doomed banks to exit. As a benchmark Hokkaido Takushoku has been formally dead for 18 months but it assets are still largely in the banking system. Our forecasts require that the assets of a failed institution are disposed of, not merely moved into another banks. The Hokkaido Takushoku experience suggests that the re-organization could take years, although we see no reason to expect it to take more than a decade. Thus, overall, we expect the transition to the new steady state to be relatively complete by the end of the next decade. 


\section{References}

Aoki, Masahiko and Hugh Patrick, 1994, The Japanese Main Bank System: Its Relevance for Developing and Transforming Economies, Oxford University Press.

Atkinson, David, 1998, "Nihon ni Oote Ginko ha 2-4 ko shika Hitsuyo denai" (Japan Needs no more than 2-4 Major Banks), Goldman Sachs Investment Research.

Bank of Japan, Bank Supervision Department (1997) “Sin'yo Risuku Kanri no Koudo-ka ni muketa Jiko Satei no Katsuyo ni tsuite" (Using Self Examination to improve Credit Risk Management), Nihon Ginko Geppo, October Issue, 1-16.

Bank of Japan, Flow of Funds Accounts.

Bayoumi Tamin, 1998, "The Morning After: Explaining the Slowdown in Japanese Growth in the 1990", IMF working paper.

Berger, Allen and Gregory Udell, 1995, "Lines of Credit and Relationship Lending in Small Firm Finance," Journal of Business 68: 351-381.

Cai, Jun, K.C. Chan and Takeshi Yamada, 1996, "The Performance of Japanese Mutual Funds," Columbia University, Center on Japanese Economy and Business Working Paper \#107.

Cargill, Thomas, 1999, "What Caused the Current Banking Crisis?" manuscript, University of Nevada, Reno.

Cargill, Thomas F., Michael M. Hutchison, and Takatoshi Ito, 1997, The Political Economy of Japanese Monetary Policy. Cambridge, MA; MIT Press.

Choy, Jon, 1999, "Japan's Banking Industry: The 'Convoy' Disperses in Stormy Seas," Japan Economic Institute Report No.10A.

Corbett, Jenny, 1999a, "Crisis what Crisis? The Policy Response to Japan's Banking Crisis", in C. Freeman editor, Why did Japan Stumble? Causes and Cures, Edward Elgar, forthcoming.

Corbett, Jenny, 1999b, "Japan's Banking Crisis in International Perspective", in M. Aoki and G. Saxonhouse editors, Finance, Governance, and Competitiveness, Oxford University Press, forthcoming.

Craig, Valentine V., 1998, "Financial Deregulation in Japan”, FDIC Banking Review, pp. 1-12, volume 11 , number 3 . 
Dale, Richard, 1992, International Banking Deregulation: The Great Banking Experiment, Blackwell Finance.

Economic Planning Agency, 1998, Keizai Hakusho (Economic White Paper)

Federal Reserve Board, Flow of Funds Accounts.

Federation of Bankers Associations of Japan, Analysis of Financial Statements of All Banks, various issues.

Federation of Bankers Associations of Japan, Analysis of Interim Financial Statements of All Banks, various issues.

Financial Supervisory Agency web site (www.fsa.go.jp)

Fiorillo, James ,1999a, private correspondence.

Fiorillo, James, 1999b, "Bits and Pieces: Tracking the Japanese Financial System, May 19, 1999 report", ING Barings, mimeo.

Fukao, Mitsuhiro, 1999, "Re-capitalizing Japan's Banks: The functions and problems of the Financial Revitalization Act and the Bank Recapitalization Act", mimeo, Keio University.

Gertler, Mark and Simon Gilchrist, 1994, "Monetary Policy, Business Cycles, and the Behavior of Small Manufacturing Firms”, Quarterly Journal of Economics, 59, pp. 309-340.

Hamada, Koichi, and Akiyoshi Horiuchi, 1987, "The Political Economy of Financial Markets," in Kozo Yamamura and Yasukichi Yasuba (Eds.) The Political Economy of Japan: Volume 1. The Domestic Transformation. Stanford, CA: Stanford University Press, pp.223-260.

Hoshi, Takeo and Anil Kashyap, 1999, Keiretsu Financing, manuscript in progress.

Hutchison, Michael, 1998, “Are All Banking Crises Alike”, working paper, UC Santa Cruz.

International Monetary Fund, 1998a, "Japan Selected Issues”, IMF Staff Country Report No. $98 / 113$.

International Monetary Fund, 1998b, International Financial Statistics, (IMF:Washington DC).

International Monetary Fund, 1998c, World Economic Outlook May 1998, International Monetary Fund, Washington, DC.

Iwahara, Shinsaku, Yuri Okina, Yoshitsugu Kanemoto, and Kazumi Narisawa (1999), “Kin'yu 
Kikan no Furyo Saiken no Jittai to Hatan Shori Sukiimu (The Reality of Bad Loans at Financial Institutions and Schemes to Deal With Failures) in Jurist (Tokyo), 1151, 10-36.

Japan Economic Research Center, 1997, 2020 nen no Nihon no Kin'yu (Japanese Finance in 2020). Japan Economic Research Center.

Jenkinson, Timothy J, 1990, "Initial Public Offerings in the United Kingdom, the United States and Japan", Journal of the Japanese and International Economies, pp. 428-449, volume 3, number 4 .

Kashyap, Anil, Raghuram Rajan, and Jeremy Stein, 1999, "Banks as Liquidity Providers: An Explanation for the Coexistence of Lending and Deposit-Taking", NBER working paper, 6962.

Lincoln, Edward, 1998, “Japan's Financial Problems", Brookings Papers on Economic Activity 1998:2, Washington DC.

Lindgren, Carl-Johan, Gillian Garcia and Matthew I. Saal, 1996, Bank Soundness and Macroeconomic Policy, International Monetary Fund.

Milhaupt, Curtis J. and Geoffrey P. Miller, 1997, "Cooperation, Conflict, and Convergence in Japanese Finance: Evidence from the 'Jusen' Problem," Law and Policy in International Business, 29, 1-78.

Ministry of Finance, Hojin Kigyo Tokei Kiho (Quarterly Report of Incorporated Enterprise Statistics).

Moody's Investors Service, 1999, “Moody's Banking System Outlook”

Motonishi, Tazio and Hiroshi Yoshikawa, 1998, "Causes of the Long Stagnation of Japan during the 1990s: Financial or Real", Tokyo University working paper.

Naito, Keisuke, 1999, “Nihon-ban Big Bang ni yotte Toujousuru Kin'yu Shohin no Kojin Kin'yu Shisan Unyo he no Eikyo" (The Impact of New Financial Products introduced by Japanese Big Bang on Financial Investments by Individuals), Fuji Research Institute Research Paper.

Ogawa, Kazuo and S.hin-ichi Kitasaka, 1998, "Bank Lending in Japan: Its Determinants and Macroeconomic Implications", Osaka University working paper.

Ohara, Yukiko, 1996, "Japan's Banking: The Darkest Hour Before Dawn. The Future is in the Hands of MoF," Columbia University, Center on Japanese Economy and Business Working Paper \#127. 
Ohara, Yukiko, 1998, "Ginko Sector One Point (Banking Sector One Point)," SBC Warburg.

Ohmura, Keiichi, and Hidetaka Kawakita, 1992, Zeminaru Nihon no Kabushiki Shijo (Seminar Japanese Stock Markets). Tokyo: Toyo Keizai Shinpo-sha.

Organization for Economic Co-operation and Development, Bank Profitability: Financial Statements of Banks, Statistical Supplement, Organization for Economic Co-operation and Development, several issues.

Organization for Economic Co-operation and Development, Financial Accounts of OECD countries, several issues.

Organization for Economic Co-operation and Development, 1998, OECD Economic Surveys 1998: Japan, (OECD: Paris).

Packer, Frank, 1998, "The Disposal of Bad Loans in Japan: The Case of CCPC," manuscript, Federal Reserve Bank of New York.

Patrick, Hugh T., 1967, "Japan, 1868-1914," in Rondo Cameron, Olga Crisp, Hugh T. Patrick, and Richard Tilly (Eds.) Banking in the Early Stages of Industrialization. New York, NY: Oxford University Press, pp.239-289.

Patrick, Hugh T., 1971, "The Economic Muddle of the 1920's," in James W. Morley (Ed) Dilemmas of Growth in Prewar Japan. Princeton, NJ: Princeton University Press, pp.211-266.

Patrick. Hugh, 1972, "Finance, Capital Markets and Economic Growth in Japan," in Arnold W. Sametz (Ed) Financial Development and Economic Growth. New York, NY; New York University Press, pp.109-139.

Peek, Joseph and Eric Rosengren, 1997a, "The International Transmission of Financial Shocks:

The Case of Japan", American Economic Review, volume 87(4), pp. 495-505.

Peek, Joseph and Eric Rosengren, 1997b, "Collateral Damage: Effects of the Japanese Real Estate Collapse on Credit Availability and Real Activity in the United States", Federal Reserve Bank of Boston Working Paper, 97-5.

Petersen Mitchell and Raghuram Rajan, 1994, "The Benefits of Firm-Creditor Relationships: Evidence from Small Business Data", Journal of Finance, volume 49, pp 3-37.

Rajan, Raghuran and Luigi Zingales, 1998. "Financial Dependence and Growth" American Economic Review. 
Rosenbluth, Frances McCall, 1989, Financial Politics in Contemporary Japan, Ithaca, NY; Cornell University Press.

Second Financial System Committee of the Financial System Research Council, 1989, "Interim Report on 'A New Japanese Financial System'”, English translation by the Federation of Bankers Associations of Japan.

Takeda, Mashiko and Phil Turner, 1992, "The liberalisation of Japan's financial markets: some major themes", Bank of International Settlements, working paper.

Toyama, Haruyuki, 1998, "The Monetary, Regulatory and Competitive Implications of the Restructuring of the Japanese Banking Industry", Bank of Japan, working paper.

Ueda, Kazuo, 1998, "Causes of the Japanese Banking Instability in the 1990s," manuscript, Bank of Japan.

U.S. Bureau of the Census, Quarterly Financial Report for Manufacturing, Mining, and Trade Corporations (QFR), various issues.

Woo, David, 1998, "In Search of "Capital Crunch": Supply Factors Behind the Credit Slowdown in Japan", working paper IMF.

White, Halbert, 1980, “A Heteroskedasticity-consistent covariance matrix estimator and a direct test for heteroskedasticity, Econometrica, 48, 817-838.

Yonezawa, Yasuhiro, and Junko Maru, 1984, Nihon no Kabushiki Shijo (Japanese Stock Markets). Tokyo: Toyo Keizai Shinpo-sha. 
</ref_section> 


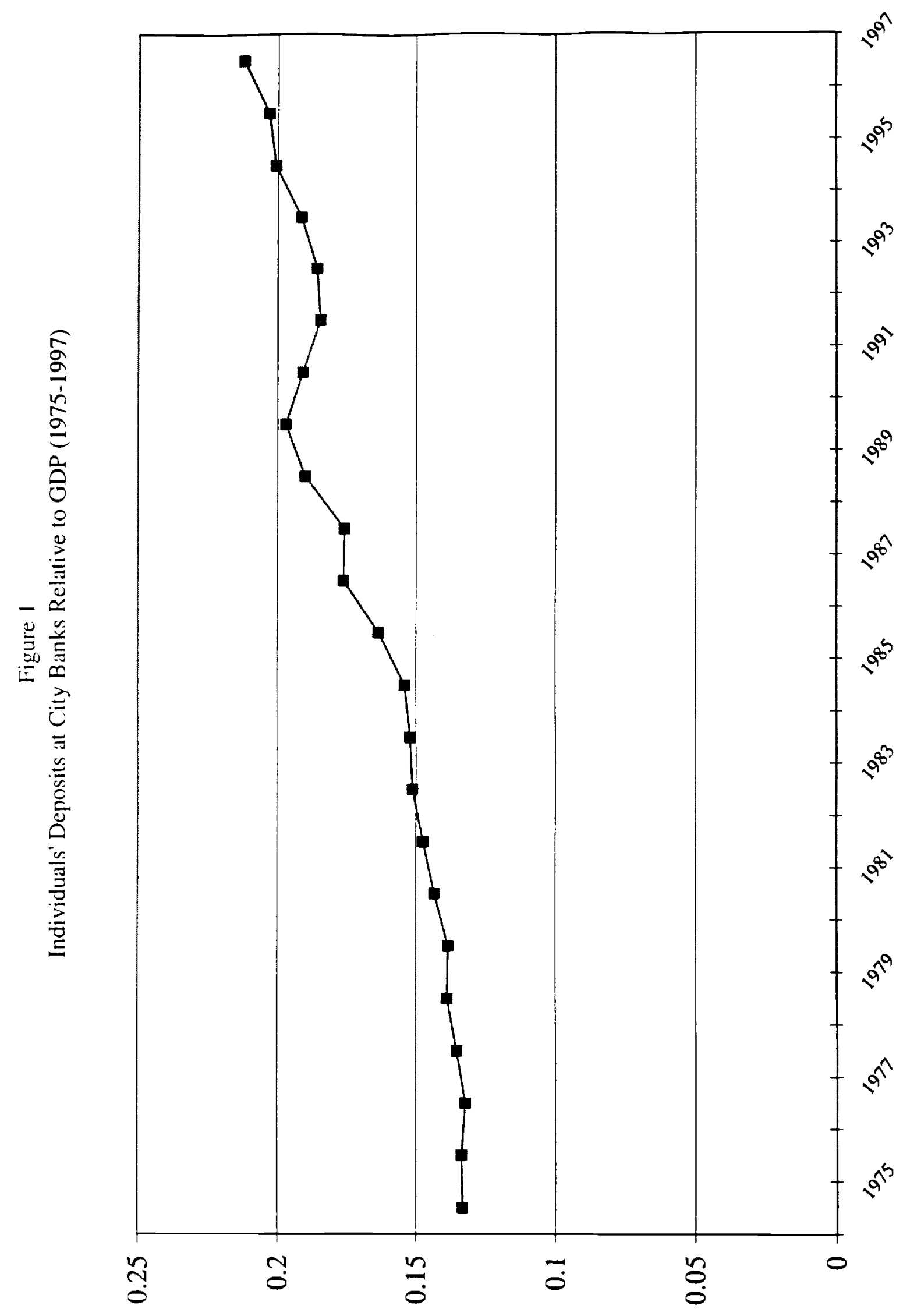

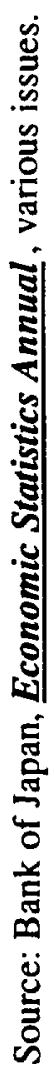




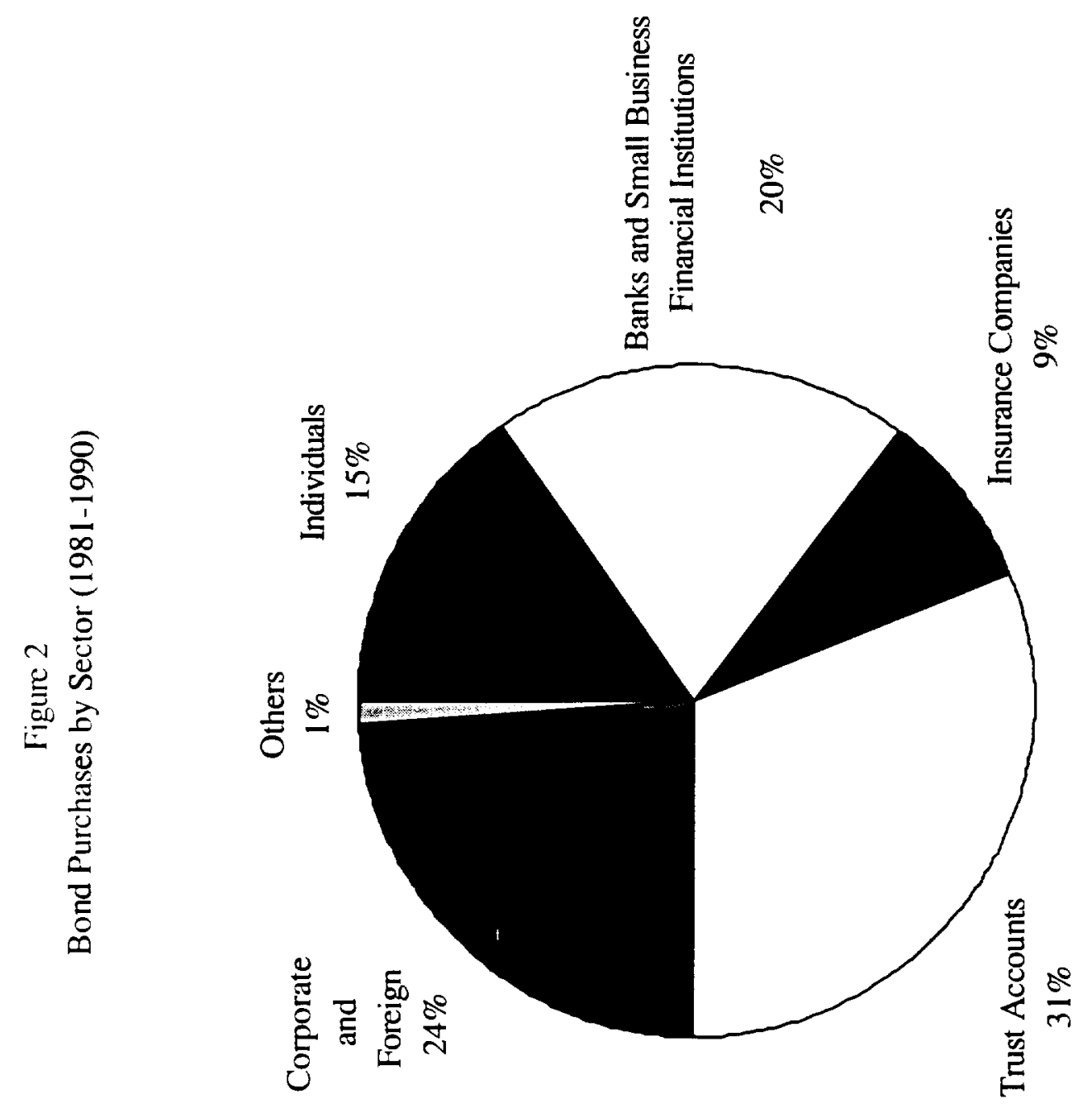




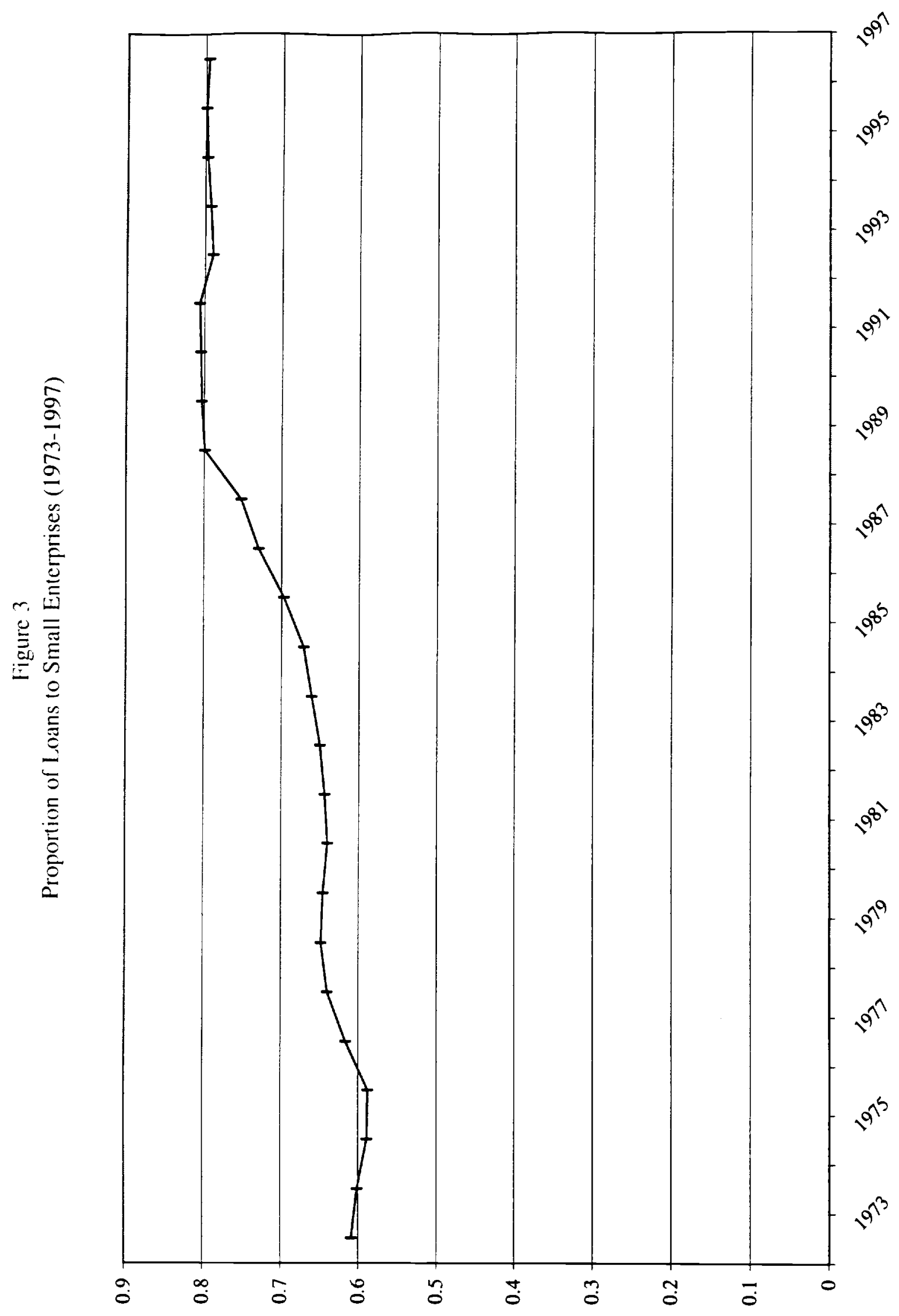

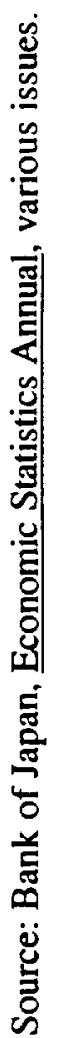




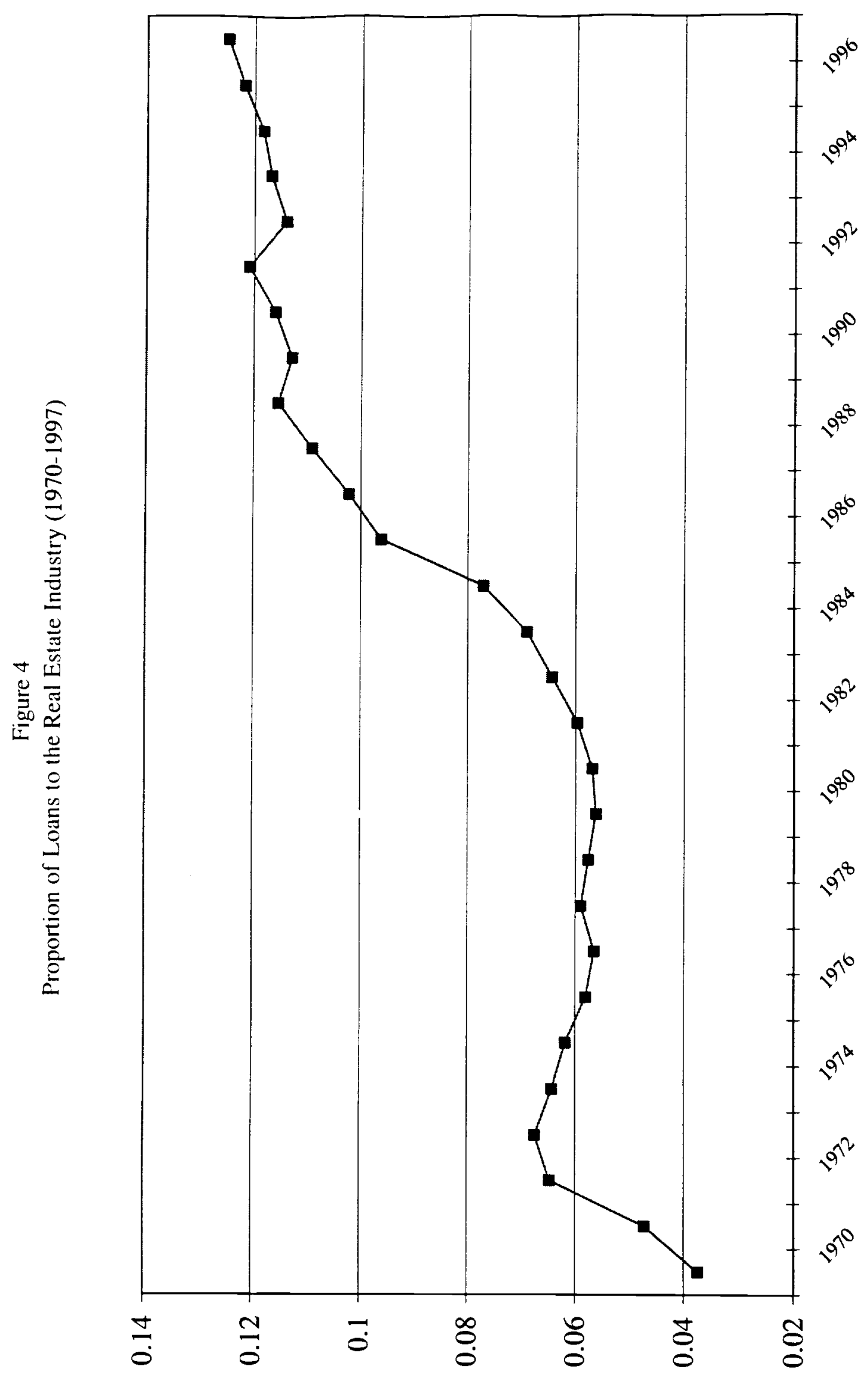

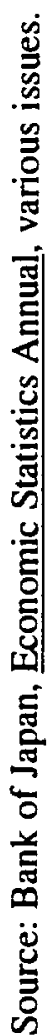



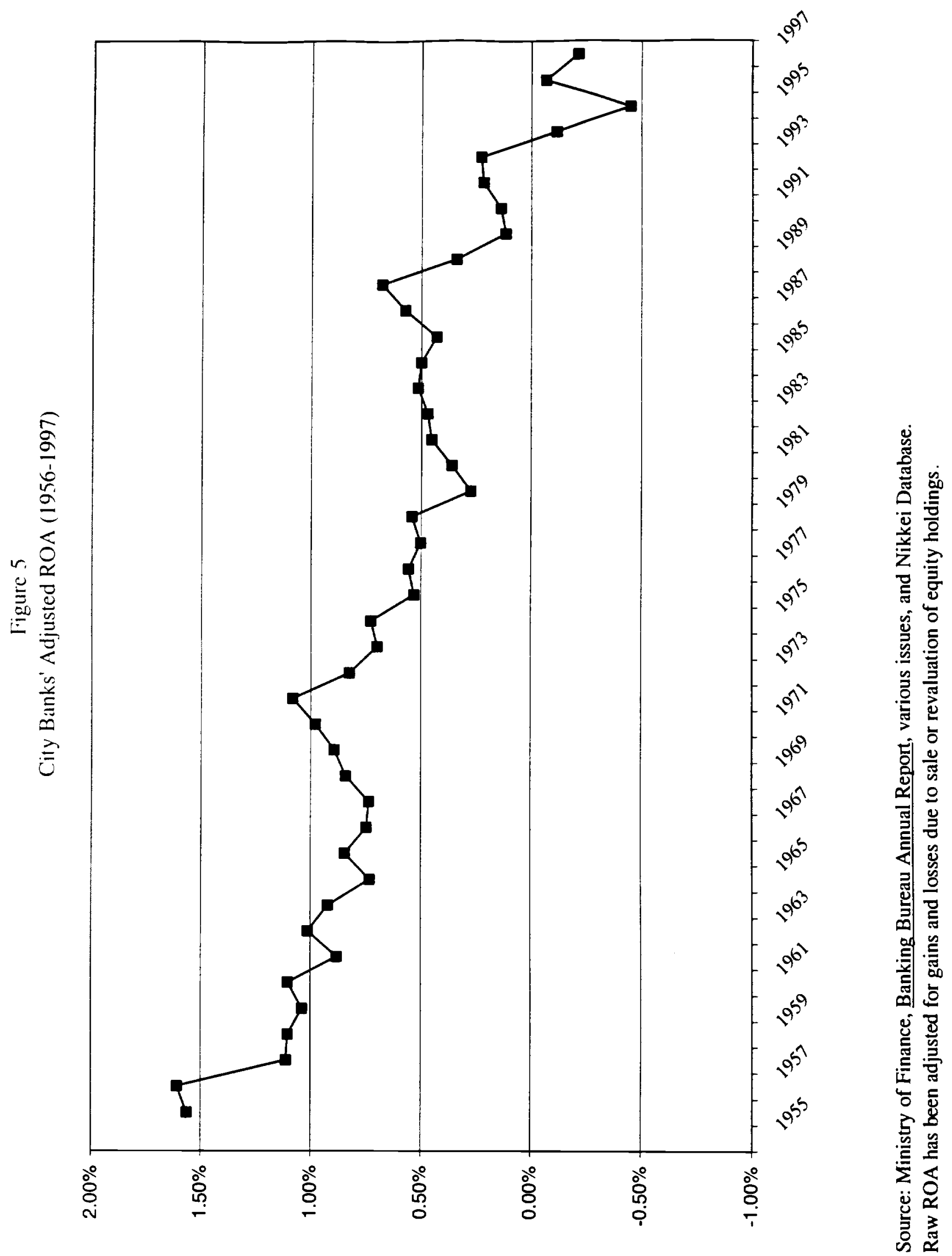


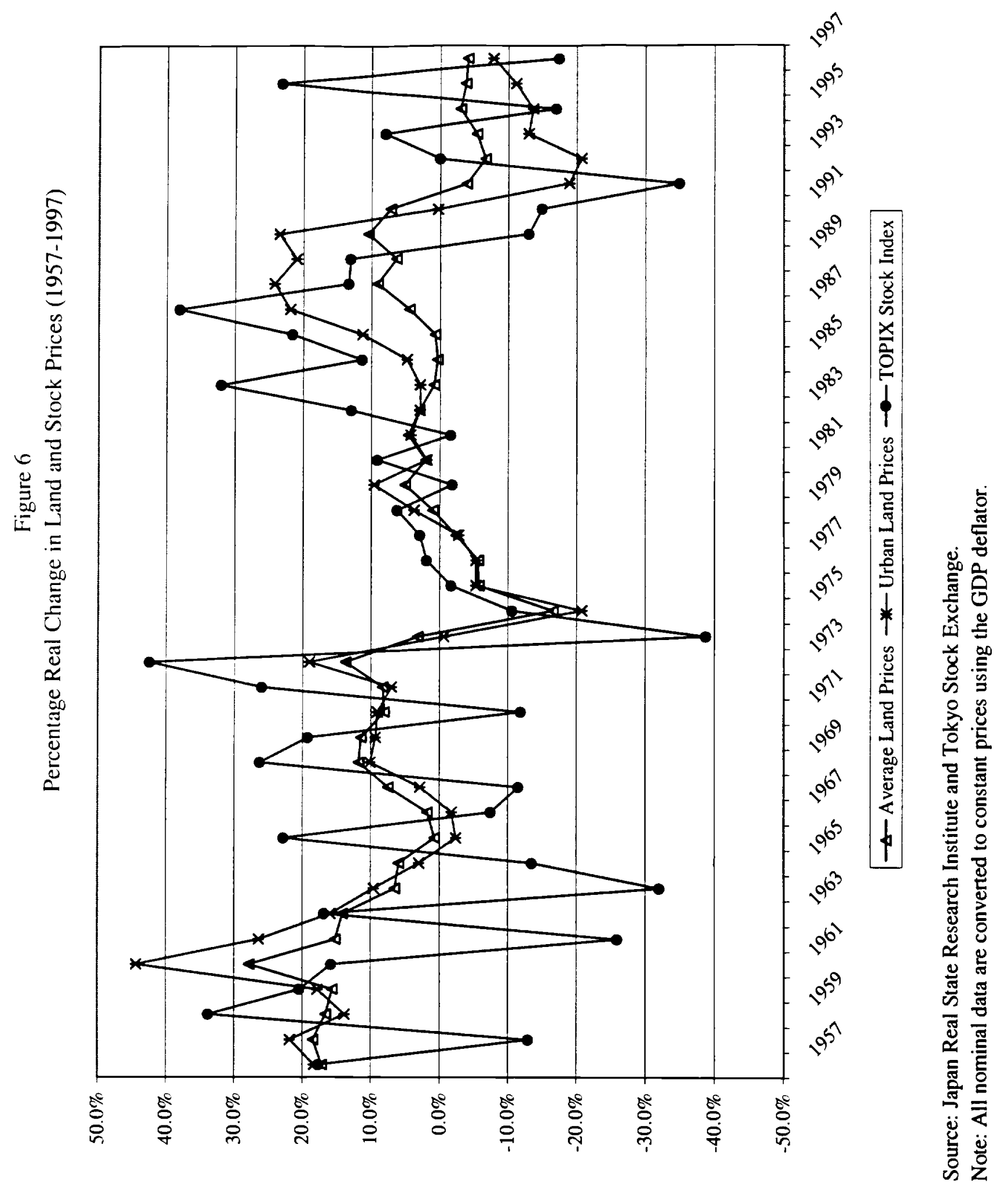




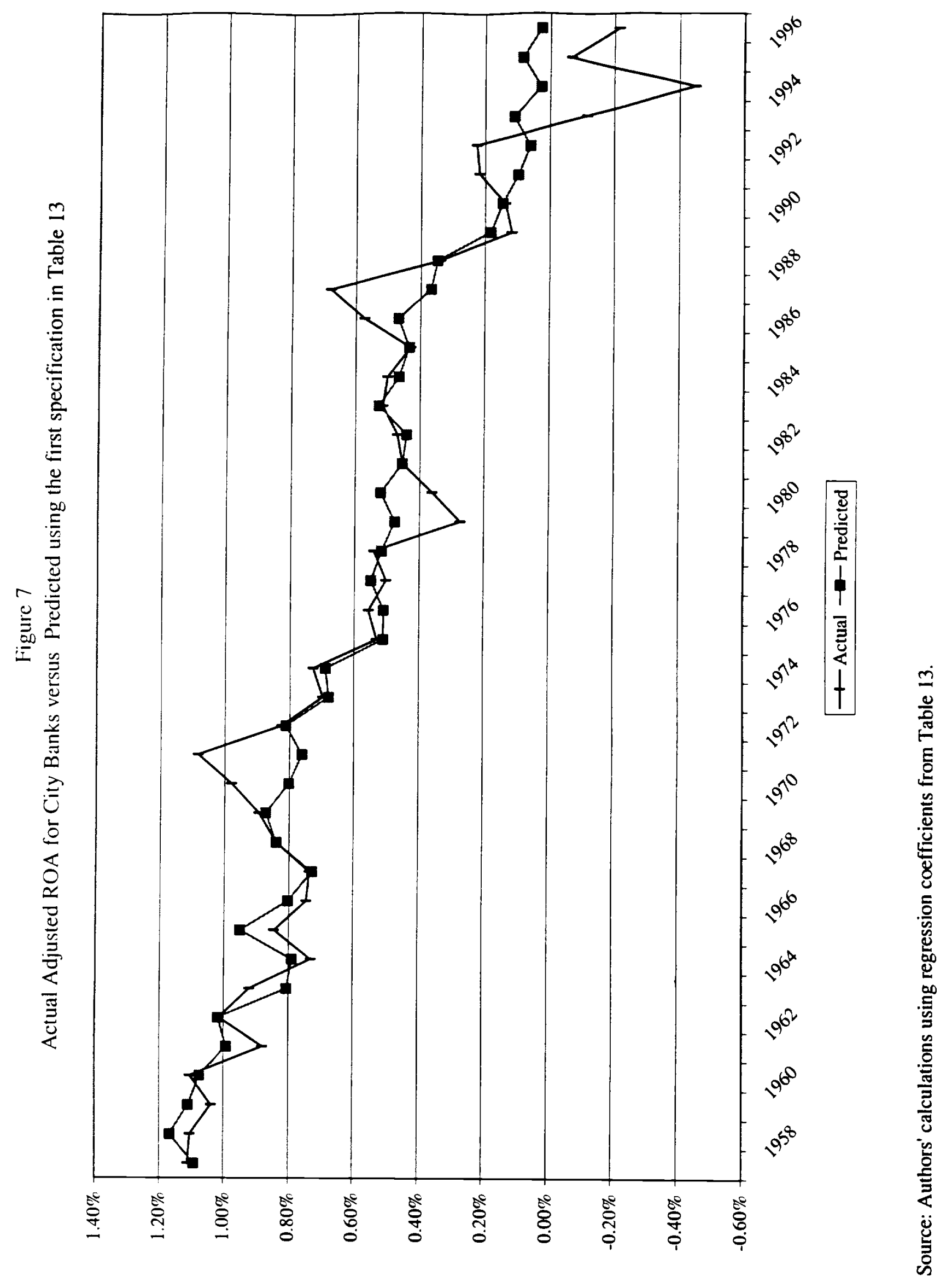




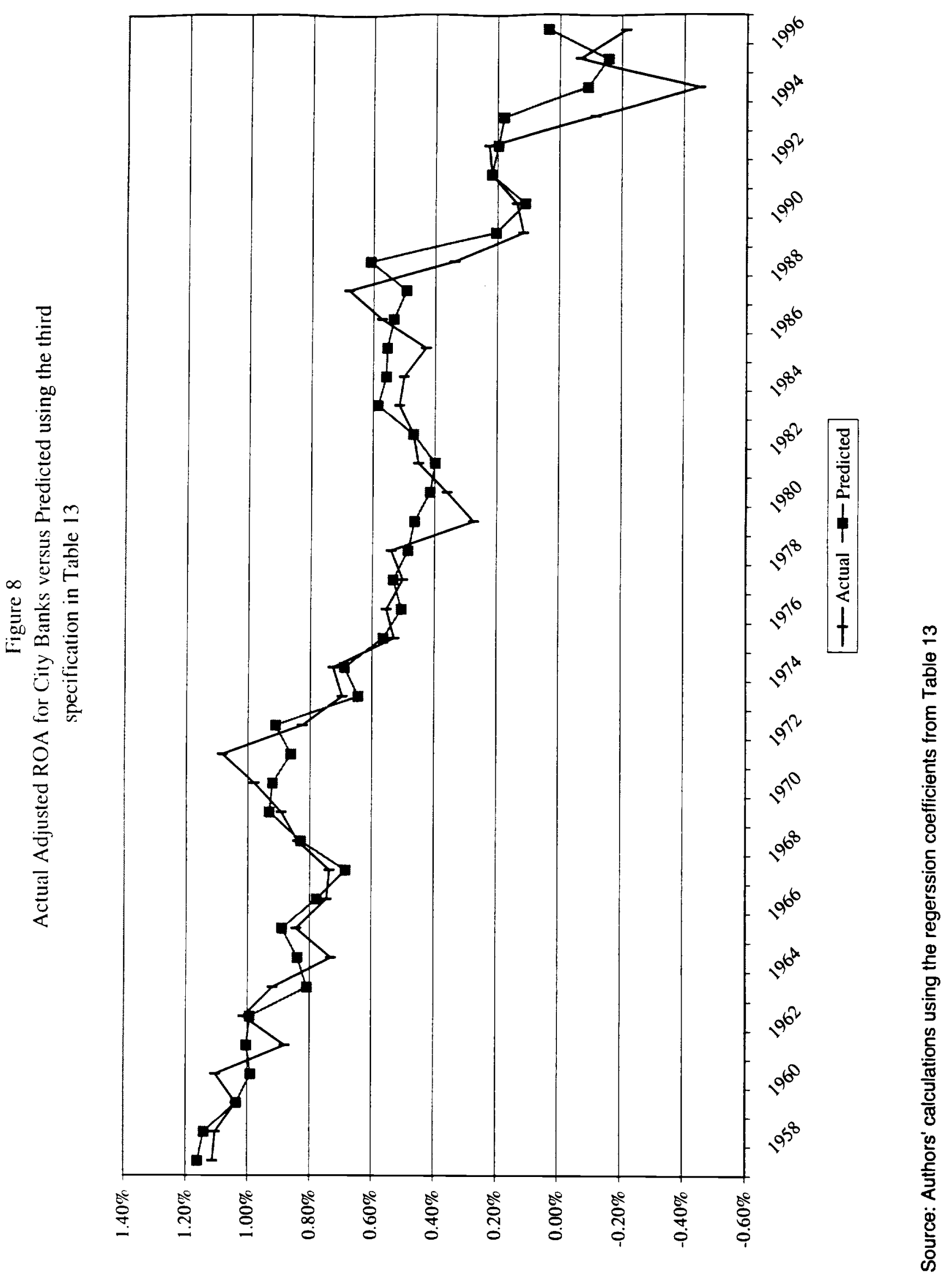




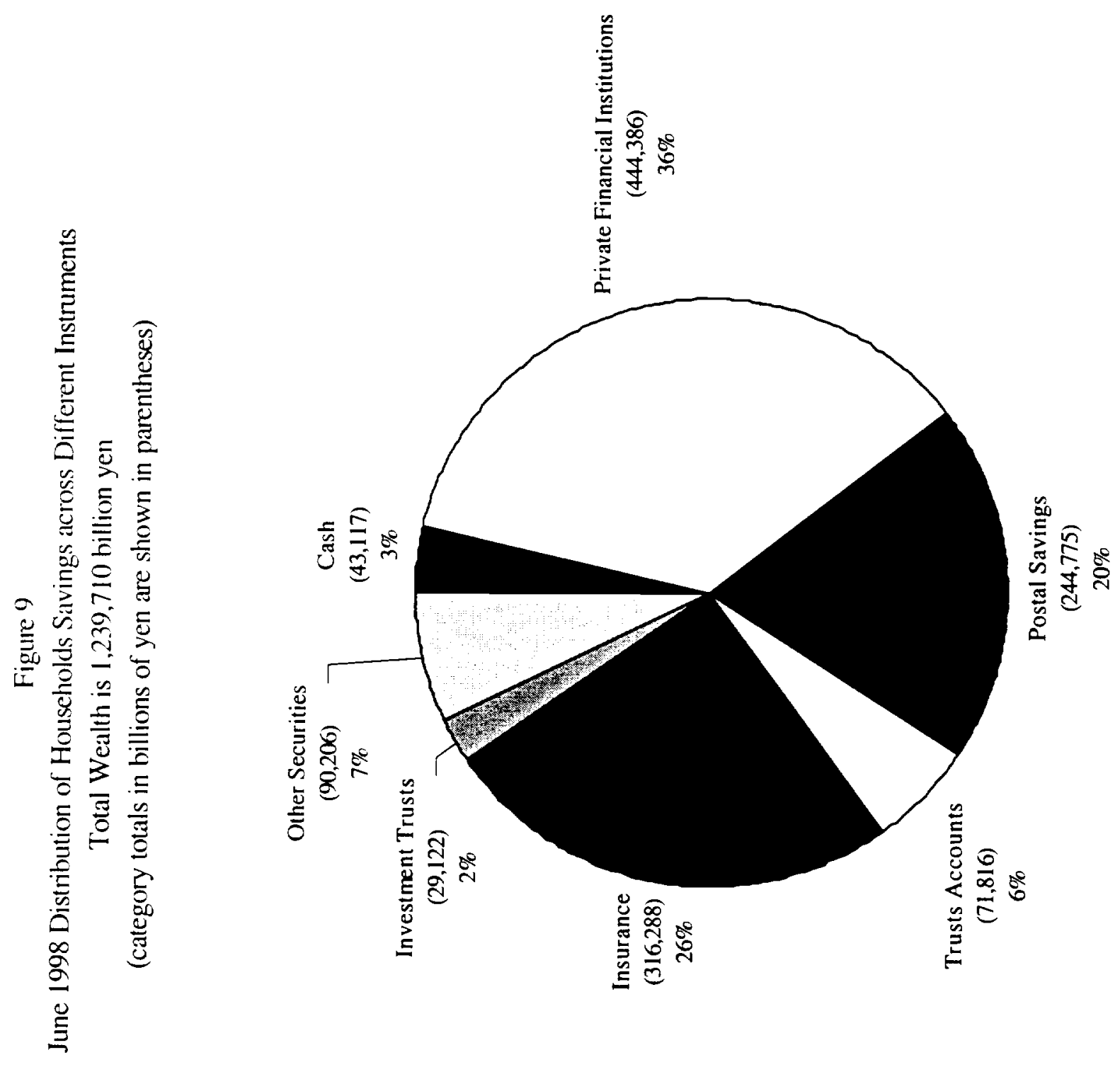

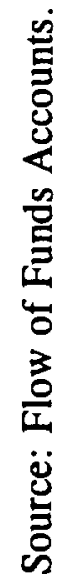




\section{Table 1}

Significant events affecting the choices available to Japanese savers

1979

Negotiable CD market is setup

1981

Maturity-designated time deposits are introduced (up to 3 yrs); new type of loan trust fund (called "Big") accounts introduced by trust banks.

1982

Money market dealers allowed to begin buying bills; Securities companies banned from selling foreign-currency zero-coupon Euro-bonds to residents (ban lifted subject to certain restrictions in Feb 83)

1983 Banks start over-the-counter sale of government bonds to the general public; government bond time deposit account is introduced; medium-term government bond time deposit account is introduced; Postal insurance system permitted to invest in foreign bonds; banks authorized to sell long-term government bonds and medium-term government bonds over the counter

1984 Short-term Euro-yen loans to residents liberalized; Domestic trade in CDs and CPs issued abroad permitted.

1985 Initial relaxation of time deposit rates (for deposits over 1 billion yen) and money market certificate (MMC) rates (interest rate ceiling of $0.75 \%$ below weekly average newly issued $C D$ rate); bankers' acceptance market created;

1986 Treasury bill auction begins

1987 Freely determined interest rates permitted for time deposit accounts over 100 million yen

1988 Postal savings system allowed to progressively increase foreign investments and to diversify domestic investments (no longer obligated to place all its funds with the Trust Fund Bureau)

1989 Introduction of small-lot MMCs (minimum lot $¥ 3$ million); Unregulated interest rates for time deposits over 10 million yen

1990 Interest rate ceilings for money market certificates removed; residents are allowed to hold deposits of up to $¥ 30$ million with banks overseas without prior authorization

1991 Unregulated interest rates for time deposits over 3 million yen; Pension funds and investment trusts allowed to buy securitized corporate loans

1992 Securities houses allowed to offer money market funds (minimum deposit of $¥ 1$ million provided that more than half of such funds are invested in securities).

1993 All time deposit rate ceilings removed

1994 All major interest rates restrictions have been removed

1997 Security houses allowed to handle consumer payments for their clients; Restriction on minimum sales unit of commodity funds removed

1998 OTC sales of investment trusts by banks and insurance companies

1999 Liberalization of brokerage commissions for stock trading 


\section{Significant events in the liberalization of capital markets}

1975 Bond issuance committee begins to honor requested amounts for firms that pass the criteria

1976 Official recognition of Gensaki (repurchase agreement) transactions

1977 First issue of 5-year government bonds; first issue of Euro-yen bonds by a non-resident; secondary trading of government bonds permitted.

1978 First issue of medium-term coupon government bond (the first to be issued by auction; 3-year bonds on this occasion followed by 2-year bonds in June 1979 and 4-year bonds in June 1980)

1979 Unsecured straight bonds and unsecured convertible bonds permitted

1980 Foreign Exchange and Trade Control Act amended so "free unless prohibited" replaces "forbidden in principle"

$1981 \quad$ Warrant bonds introduced

1982 Criteria for the issuance of unsecured bonds by Japanese residents in overseas market clarified

1983 Eligibility standards for issuing unsecured convertible bonds relaxed

1984 "Real Demand Rule" for foreign exhange lifted; Swap agreements and hedging of forward foreign exchange transactions allowed; collateral requirement for non-resident issue of Euroyen bonds dropped; Freer issuance of yen-denominated CDs in Japan; standards for issuing Samurai Bonds* by private companies eased

1985 First unsecured straight corporate bond issued; bond futures introduced; first "Shogun" bond** issue; first Euro-yen straight bond issued.

1986 The credit rating system in the qualification standard fully introduced for Euro-yen bonds issued by non-residents; floating rate notes and currency conversion bonds were introduced for Euroyen issued by residents; first issue of short-term government bonds (TB); Public issue of 20year government bonds; Japan offshore market opened (minimum deposit $¥ 100$ million, minimum time 2 days)

1987 Introduction of credit rating system in the qualification standards for Euro-yen bond issues by residents; packaged stock futures market established on the Osaka Stock Exchange, ending a ban introduced in 1945; commercial paper market created

1988 Restrictions on Samurai CP issues by non-residents relaxed

1989 Tokyo International Financial Futures Exchange established; Rating criteria for bond issuance added

1990 Accounting criteria for bond issuance removed

1992 Bond issuance restrictions eased: more companies allowed to issue bonds overseas and restraints on Samurai bonds relaxed

1995 Deregulation on OTC (JASDAQ) market, creating a new market to facilitate fund-raising for start-ups

1996 All bond issuance restrictions have been removed

1998 Introduction of medium term notes; relaxation of rules governing asset backed securities

* Yen denominated public bonds which are issued in Japan by non-Japanese residents

** Foreign currency denominated bonds issued in Japan by non-residents 
Significant events relating to the range of permissible activities for banks

1979 Banks permitted to issue and deal in CDs; banks are allowed to introduce short-term "impact loans" (foreign currency loans to residents) subject to certain conditions

1980 Foreign exchange banks allowed to make medium and long-term impact loans

1982 Japanese banks permitted to lend yen overseas on a long-term basis to borrower of their choice (earlier priority system for overseas yen lending is abolished)

1983 Banks started over-the-counter sale of government bonds to the general public; Banks authorized to affiliate with mortgage securities companies

1984 Securities licenses granted to subsidiaries/affiliates of some foreign banks with branches in Japan (equity stakes limited to $50 \%$ ); permission for foreign and Japanese banks to issue Euroyen CDs with maturities of 6 months or less; banks allowed to deal on their own account in public bonds

1985 Foreign banks allowed to enter trust banking business; banks began trading in bond futures; medium and long-term Euro-yen loans to non-residents liberalized

1986 City banks authorized to issue Long-term mortgage bonds; banks' overseas subsidiaries authorized to underwrite and deal in $\mathrm{CP}$ issues abroad

1987 Banks allowed to engage in private placement of bond issues; banks begin underwriting and trading in the domestic CP market; banks allowed to deal in foreign financial futures

1988 Banks allowed to securitize home loans

1989 Banks begin brokering government bond futures; banks allowed to securitize loans to local governments.

1990 Banks allowed to securitize loans to corporations; banks allowed to enter the pension trust business through their investment advisory companies

1992 Financial System Reform Bill passed the Diet, allowing banks to set up subsidiaries to enter security business (effective April 1993)

1993 Three bureaus agreement ends, allowing banks to be lead underwriters in foreign bond issues; IBJ, LTCB, Norin Chukin Bank, Sumitomo Trust, and Mitsubishi Trust established their subsidiary security firms

1994 Major city banks established their subsidiary security firms

1998 Ban on financial holding companies lifted

1999 Banks, trust banks, and securities houses can enter each other's markets; Banks are allowed to issue straight bonds

2001 Banks and securities houses will be allowed to enter insurance business 


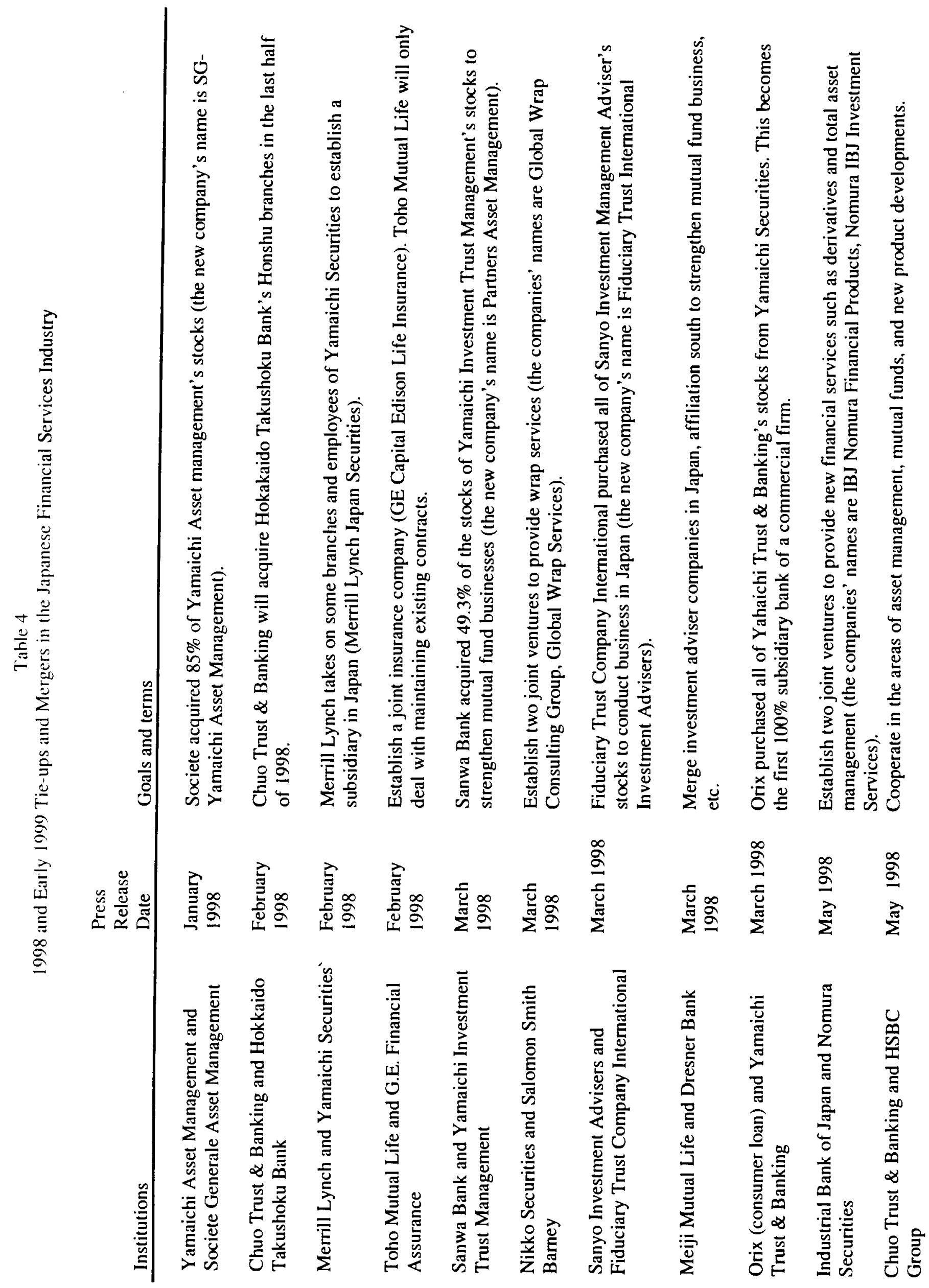




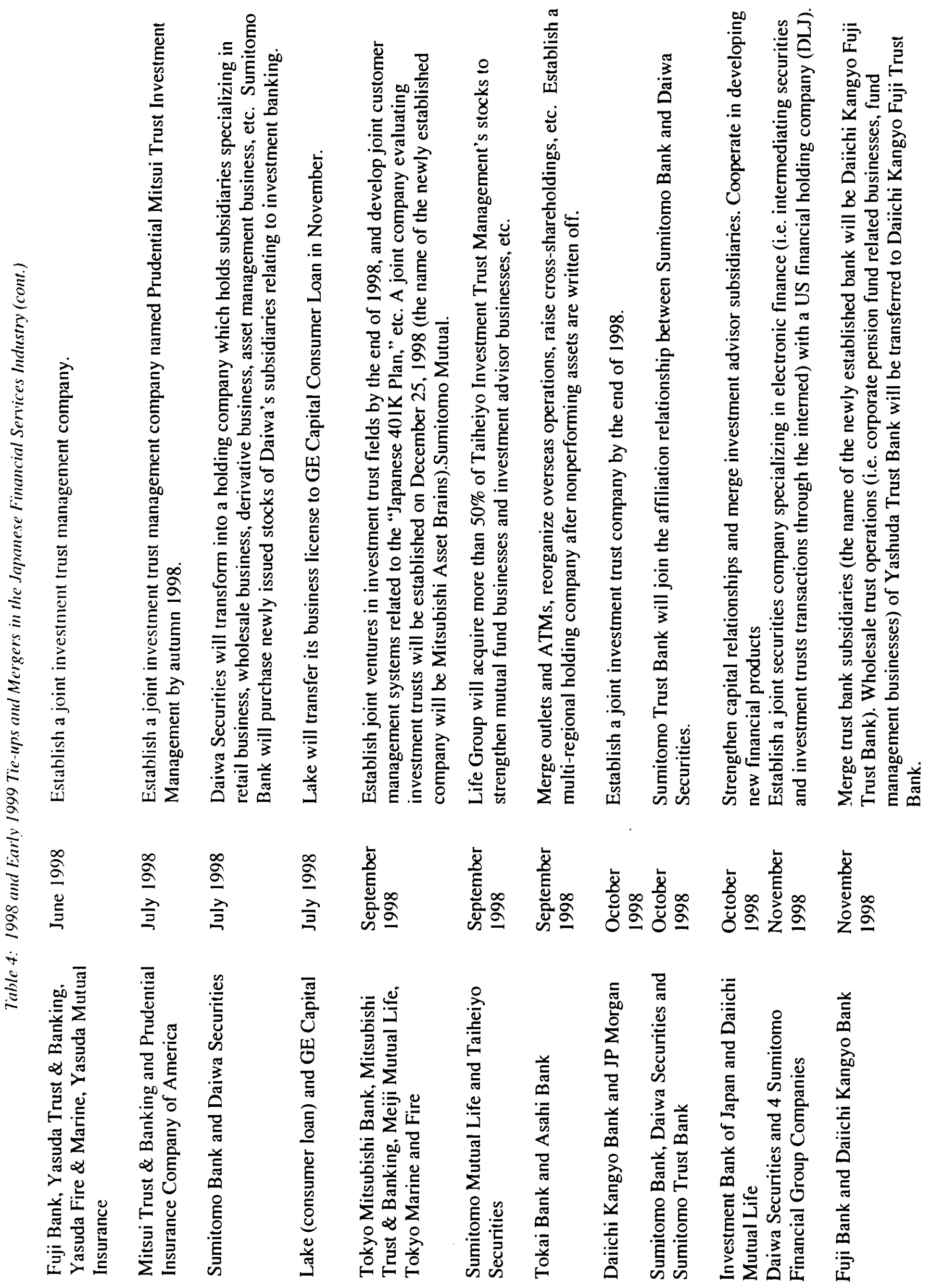




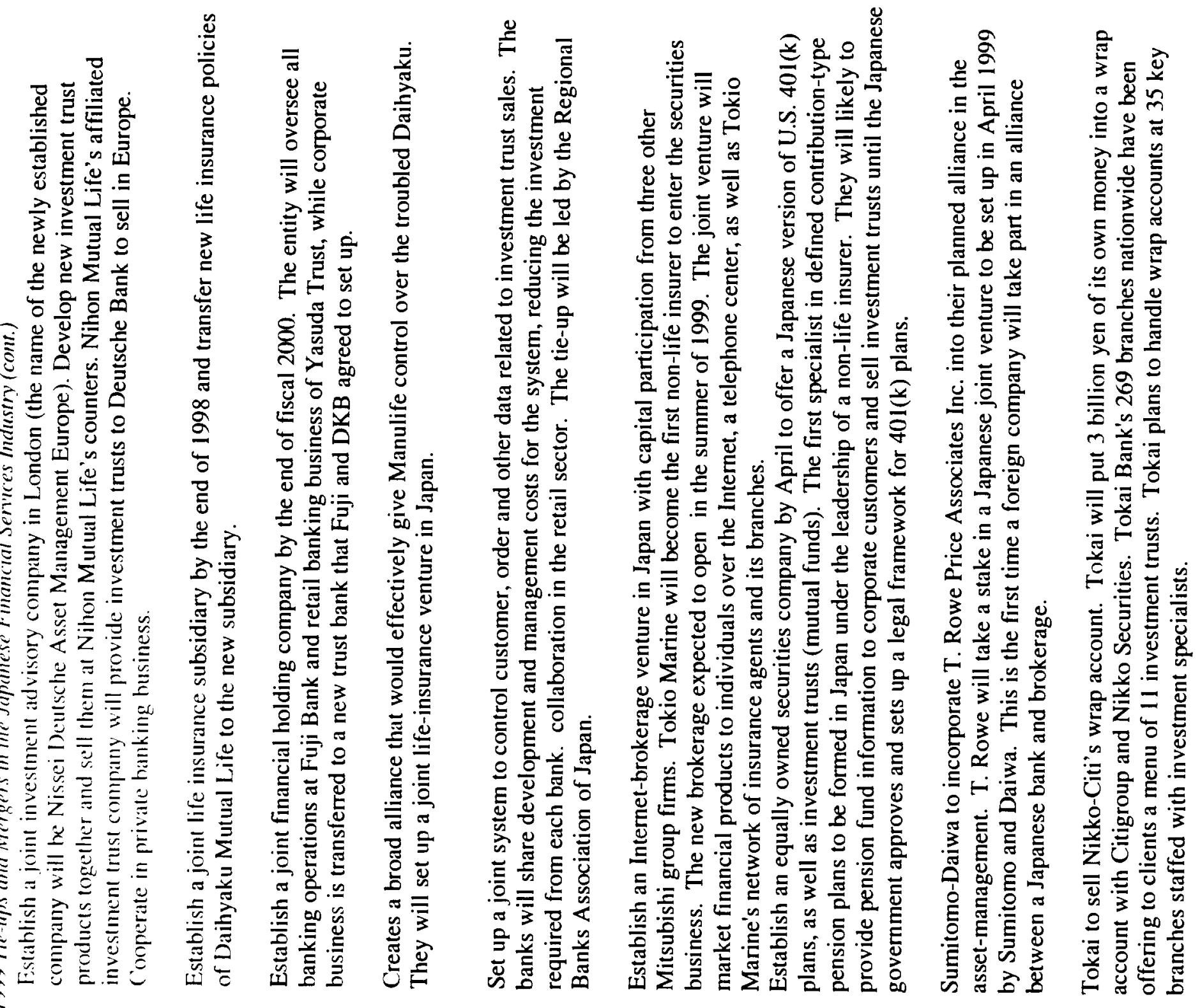

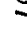
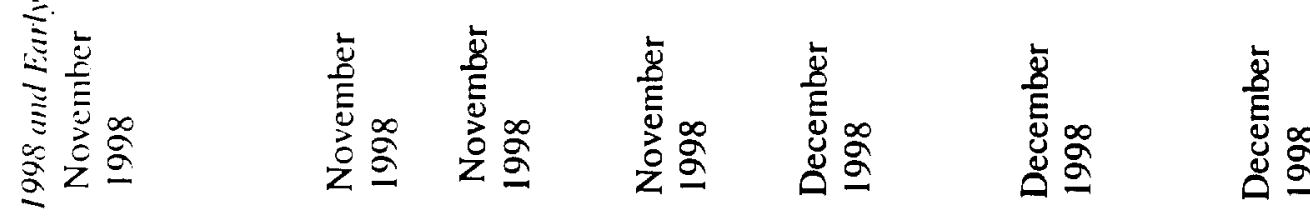

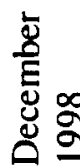

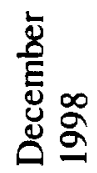

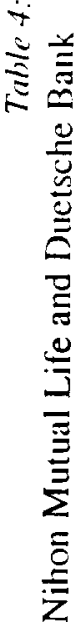
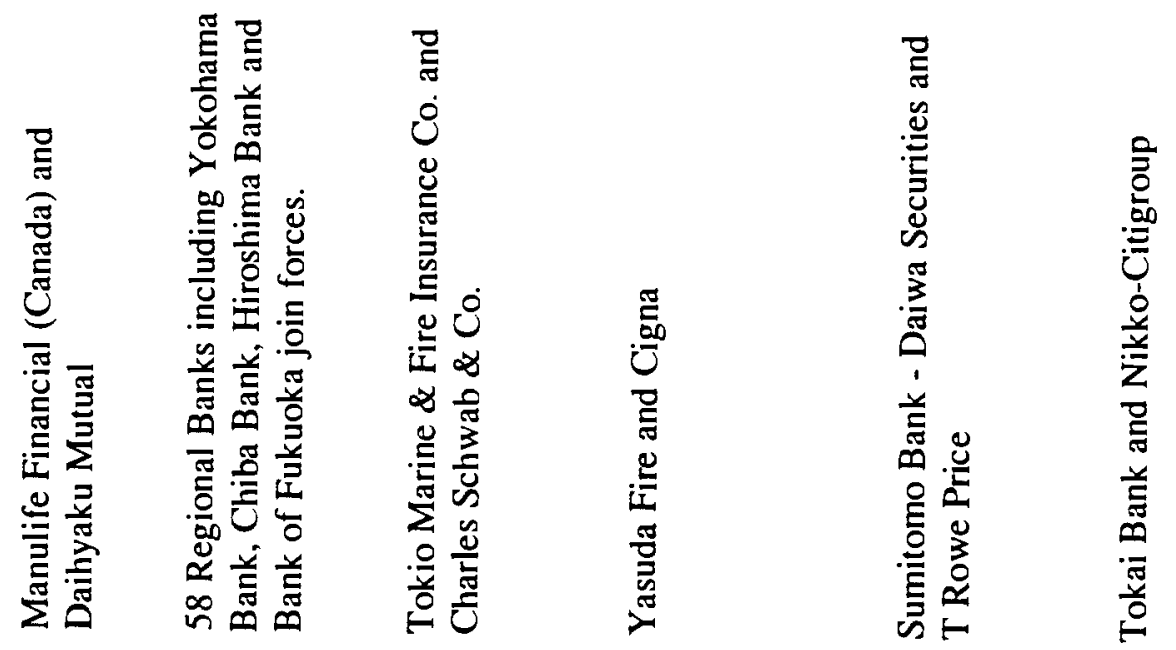


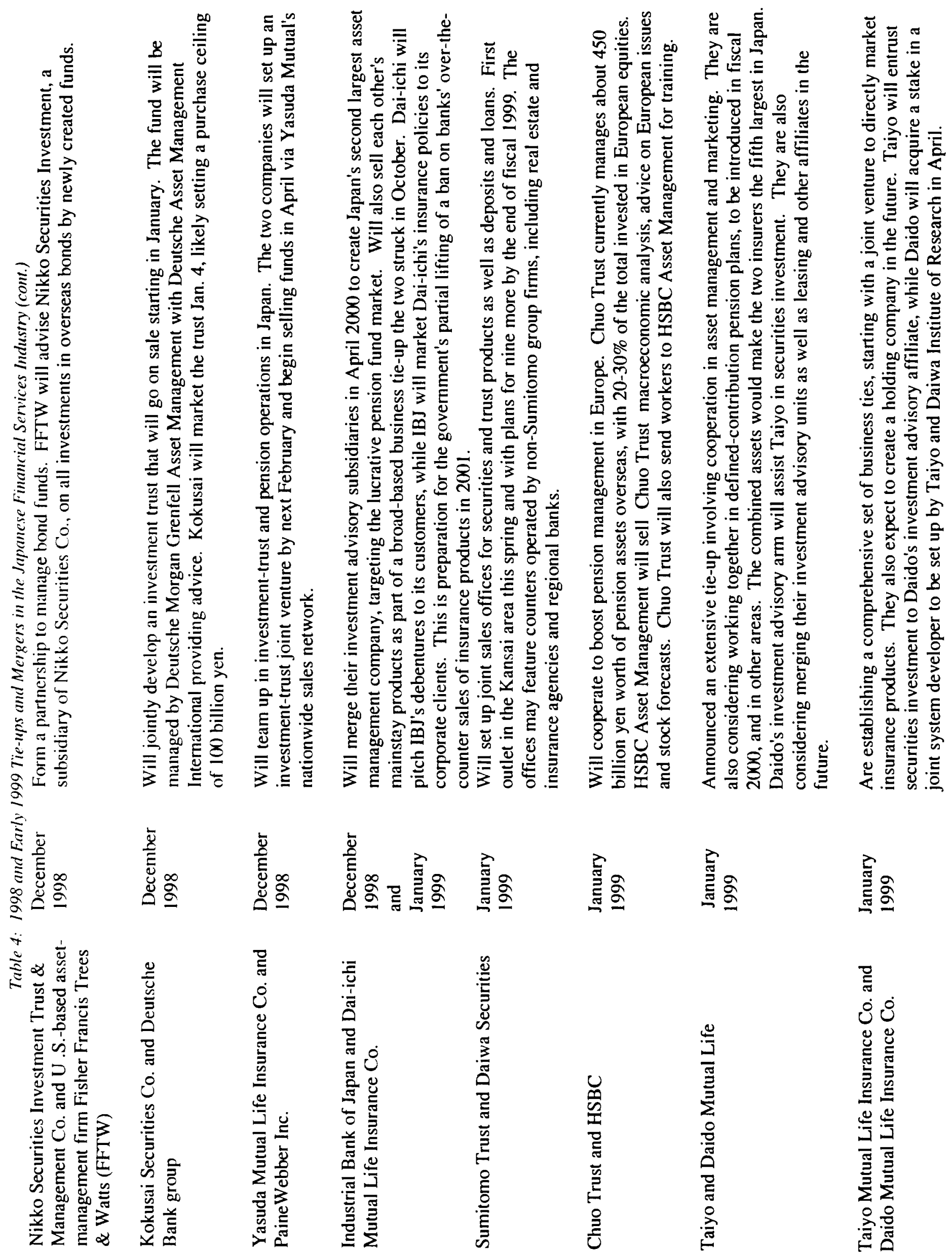




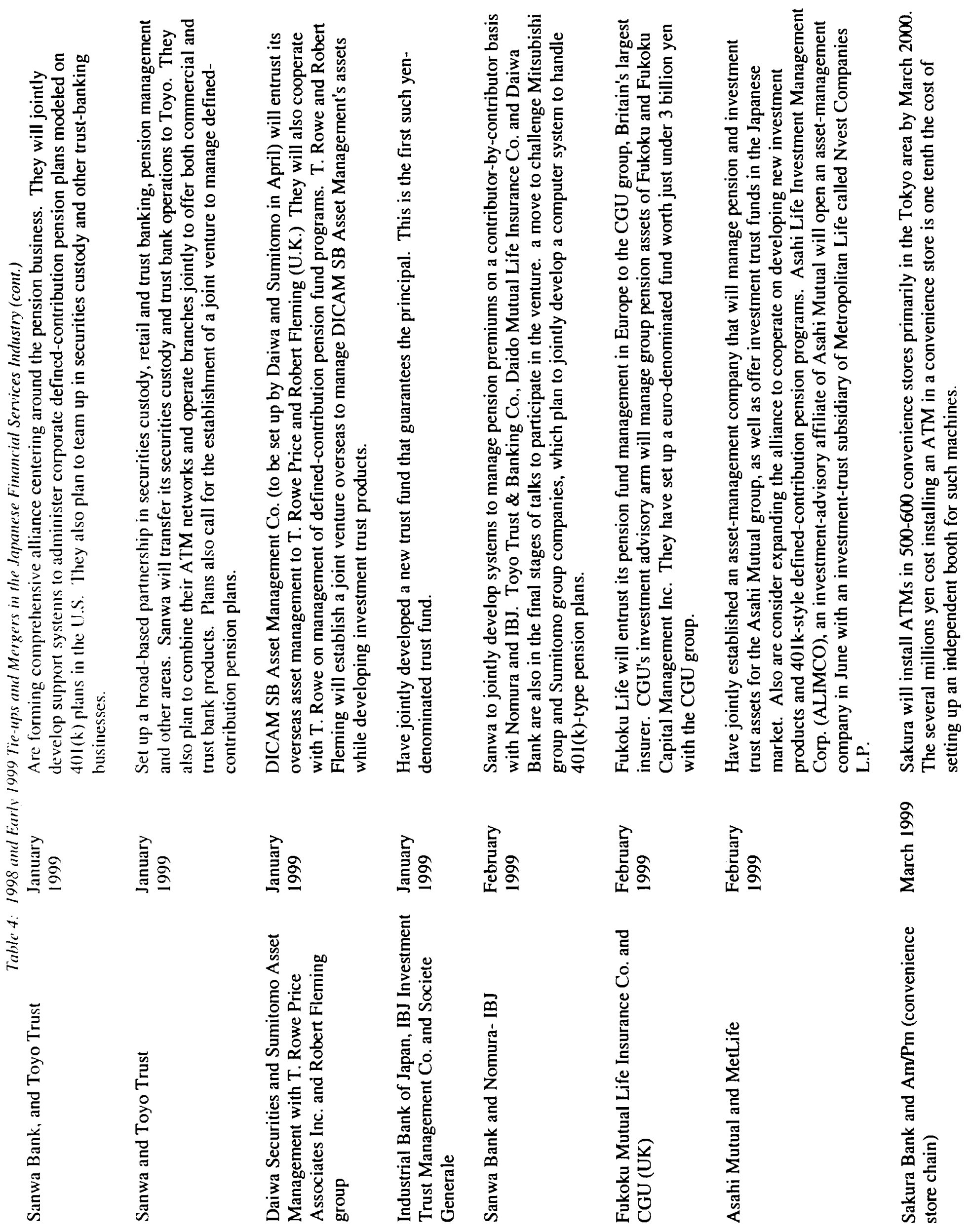




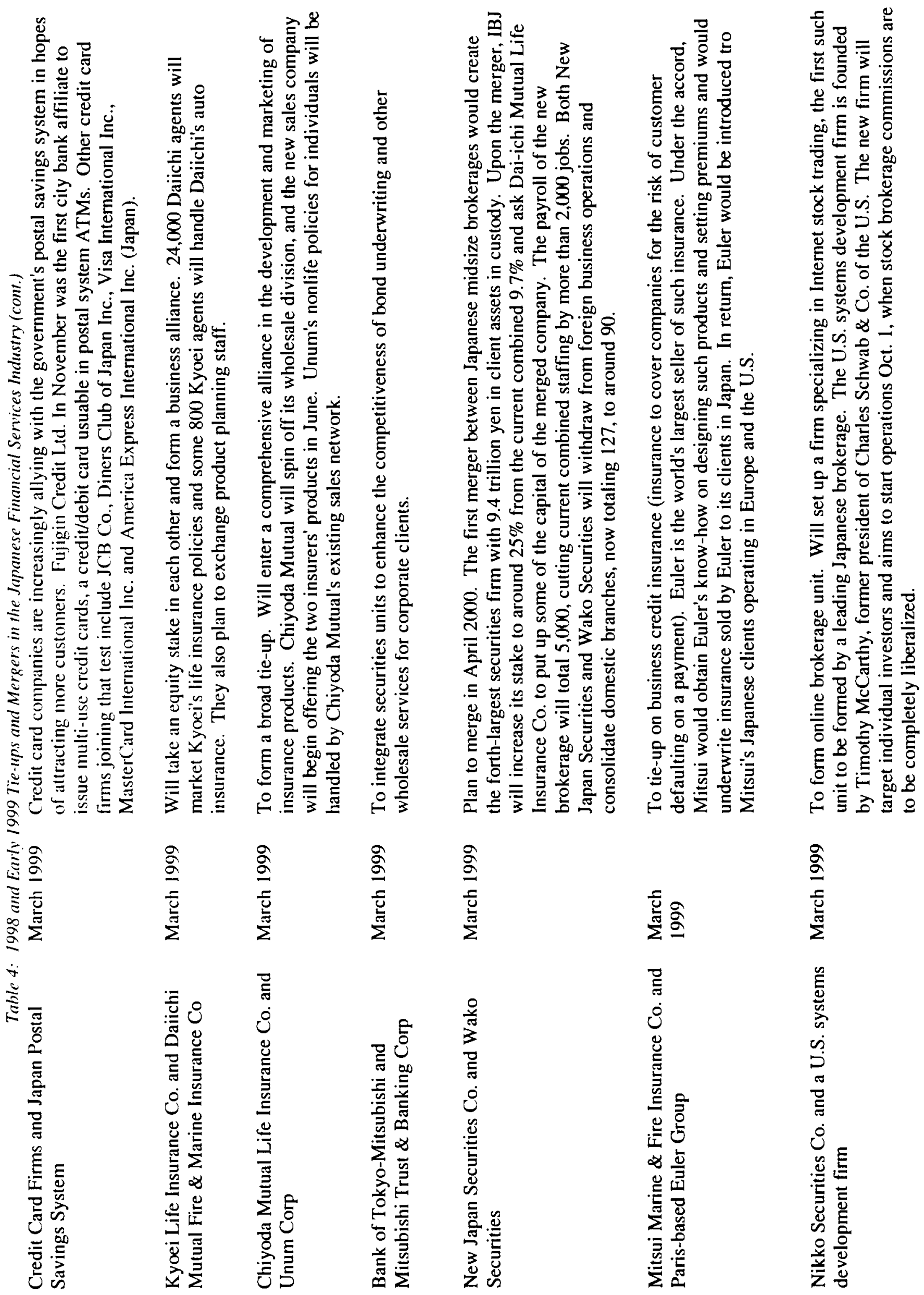




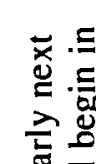

s.

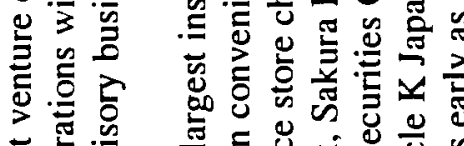

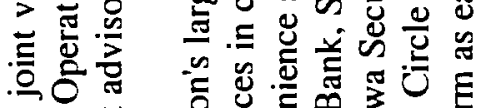

遇

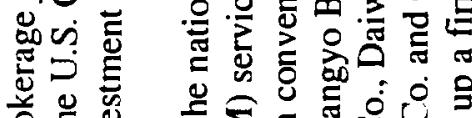

人三

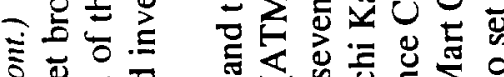

S

就导

ミ气 ฮ

용

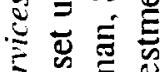

ڤั

可

ฐ

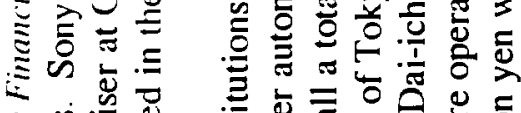

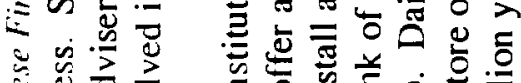

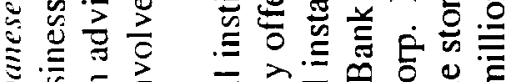

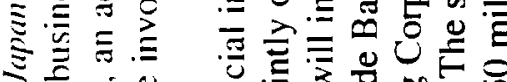

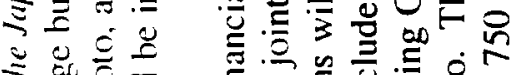

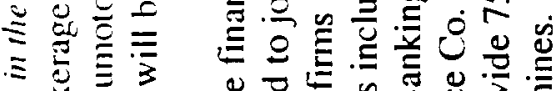

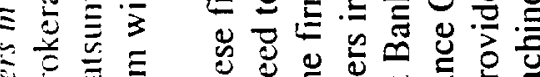

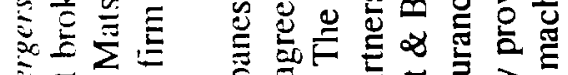

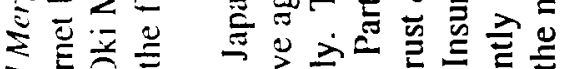

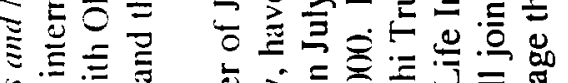

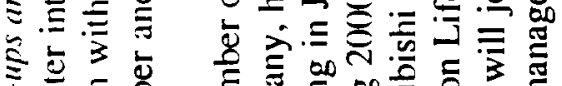

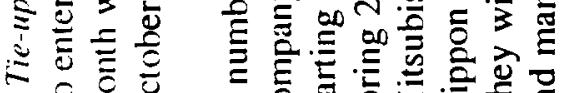

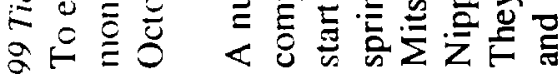

돈

$F \cdot 2$
$\dot{2} 9$

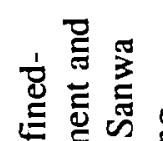

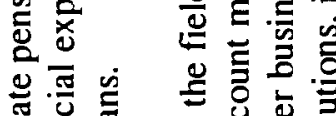

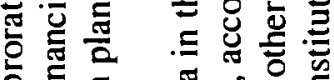

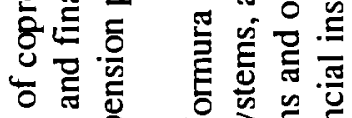

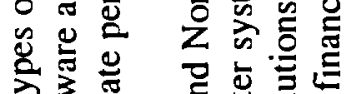

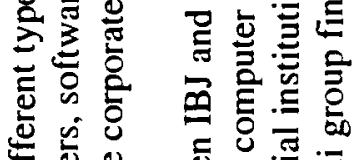

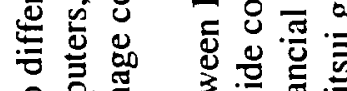

है

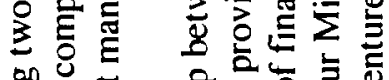

氖

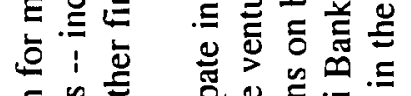

ฮี ฮิ

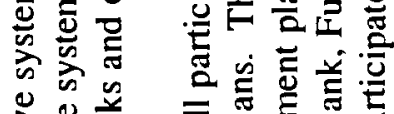

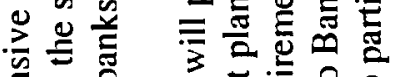

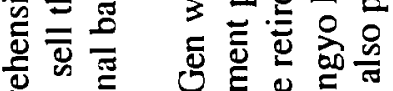

हิ ญ

을 究

过

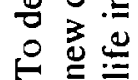

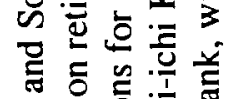

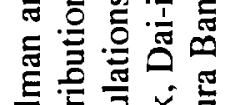

ถี

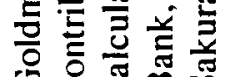

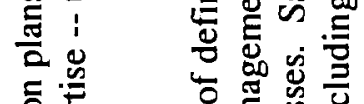

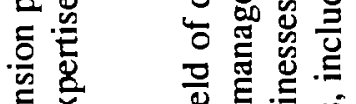

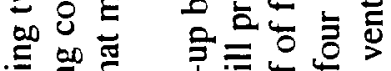

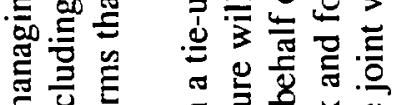

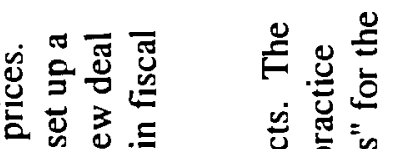

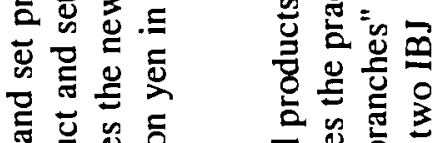

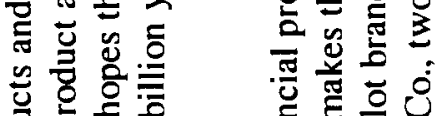

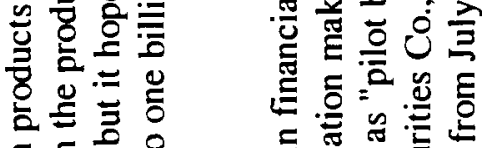

500 .

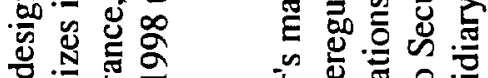

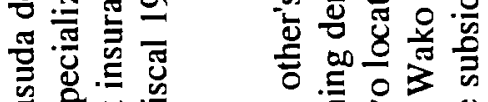

के

ป छ

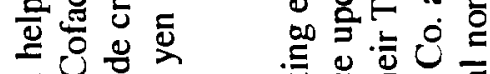

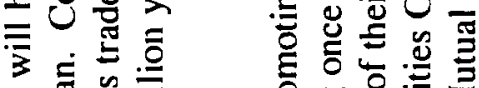

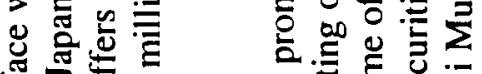

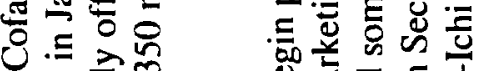

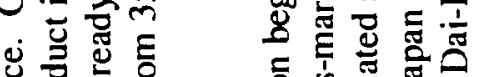

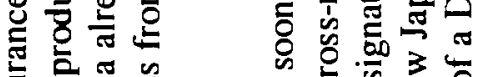

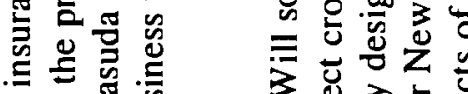

$\frac{2}{\frac{2}{2}}$

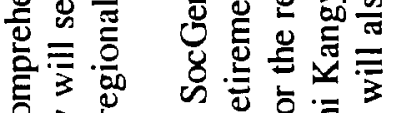

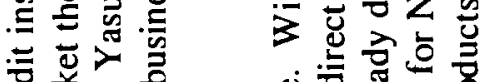

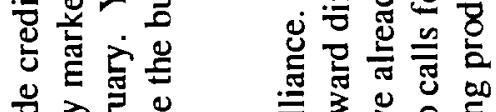

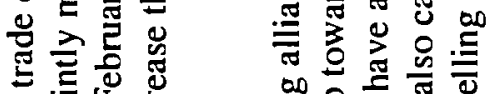

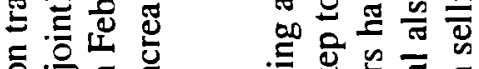

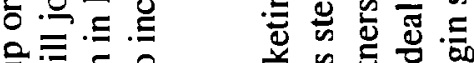

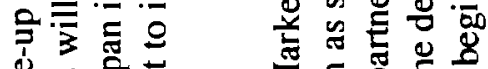

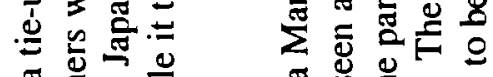

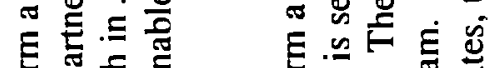

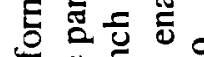

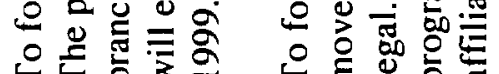

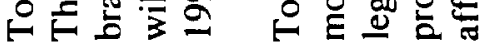

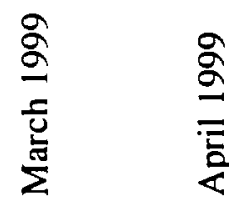

$\frac{8}{2}$

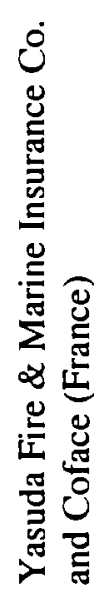

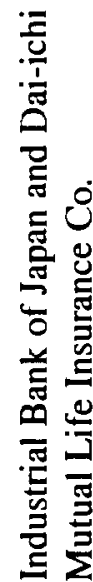

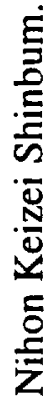

छิ

点

$\stackrel{巳}{=}$

总

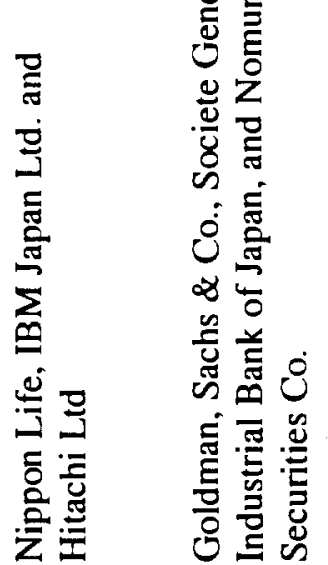

0

: 


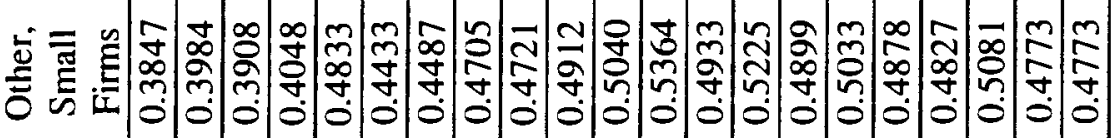

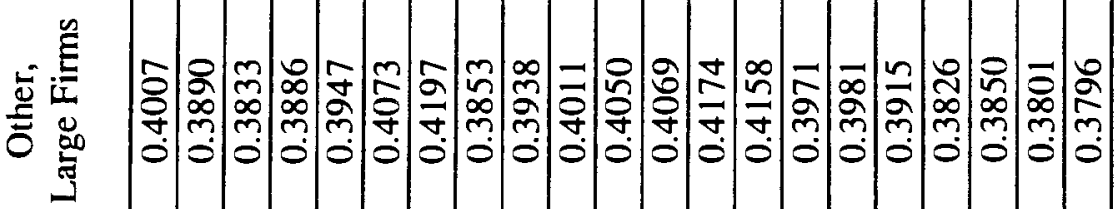

沾

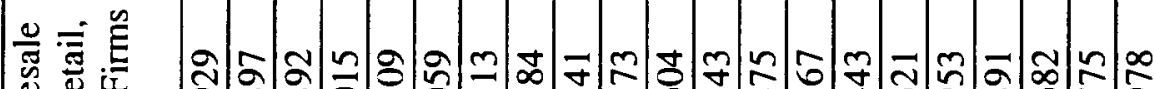

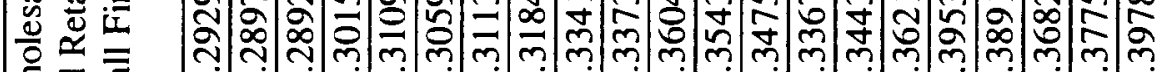

$\mathscr{\&}$

胥里

○े

$\stackrel{5}{5}$

흥

w

ष्ठ

$<\equiv$

$\subseteq \underline{5}$

동

$\bigcirc$

的兰

잉

तै

잃

$\stackrel{2}{2}$

$\stackrel{y}{\varrho}$

5

吾

它邑

0

$\circ \stackrel{0}{0}$

於苛

D

:

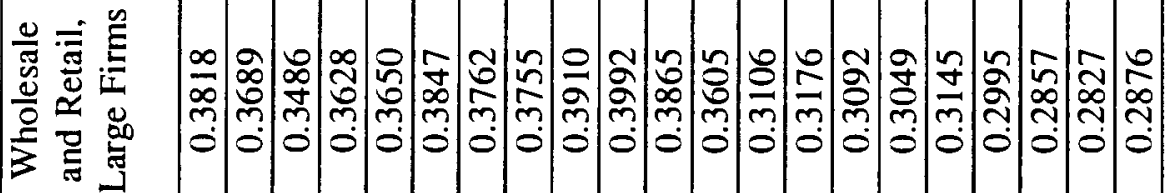

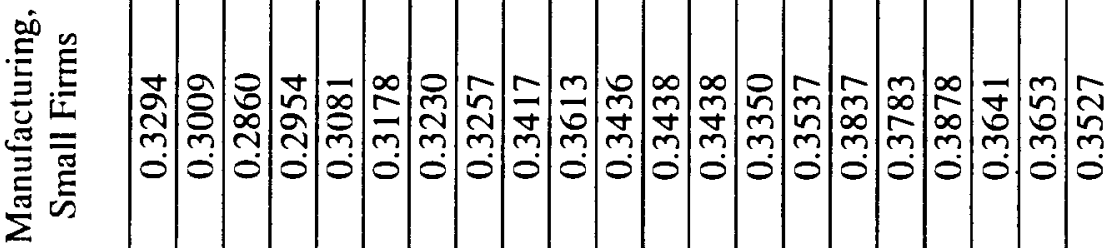

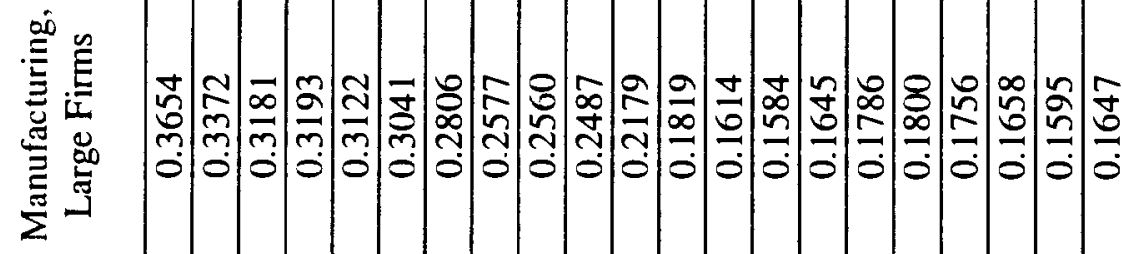

s

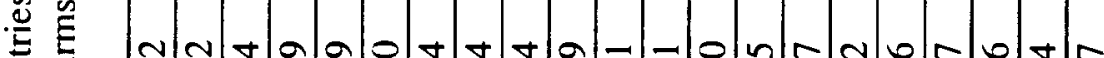

ڤ

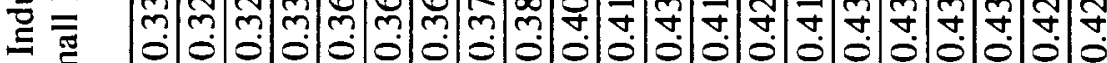

$\bar{\Sigma}$

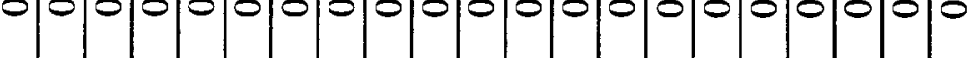

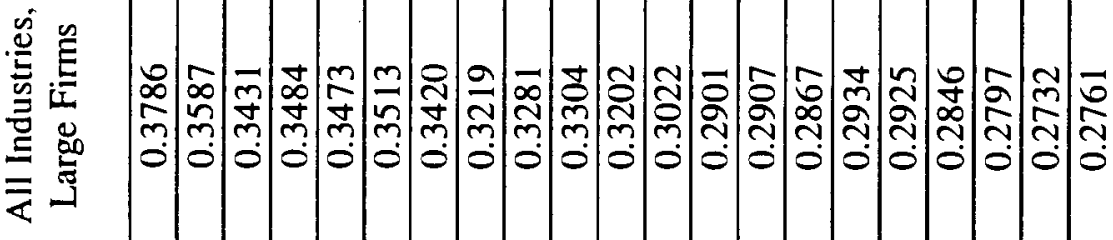

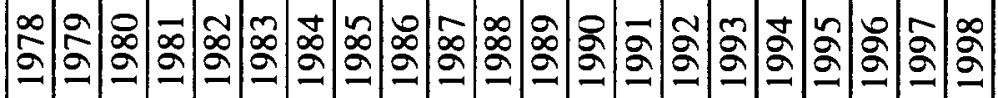

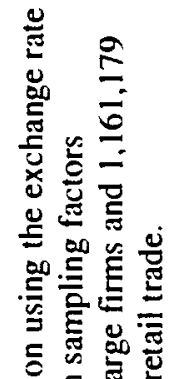

兰言至

ह 3

象능

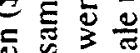

즐눤

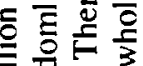

흐

- 홍응

흔 을 올

흠

홍으을

苋突

8 훙․ㅡ

웡

उ

题

员

总资

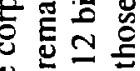

这的

స है

¿ 它

要品

的包

影

䎸

额

옳

政

ปั

용

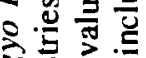

足品

․ㅡ

호ㅇㅝㅔ

的

氖㹂

旅它

드. $\infty$

ไป.

兽的

医造造

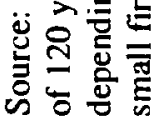


Table 6

Ratio of Bank Debt to Assets for Publicly Traded Japanese Firms Large firms are defined to have book value of assets $>¥ 120$ billion at 1990 prices

\begin{tabular}{|c|c|c|c|c|}
\hline Year & Manufacturing & Wholesale & Retail & $\begin{array}{l}\text { Non-manufacturing } \\
\text { Excluding Wholesale } \\
\text { and Retail }\end{array}$ \\
\hline 1970 & 0.3621 & 0.3006 & 0.3019 & 0.3605 \\
\hline 1971 & 0.3655 & 0.3207 & 0.3153 & 0.3620 \\
\hline 1972 & 0.3891 & 0.3438 & 0.3486 & 0.3848 \\
\hline 1973 & 0.3758 & 0.3590 & 0.3919 & 0.3961 \\
\hline 1974 & 0.3388 & 0.3170 & 0.4367 & 0.3864 \\
\hline 1975 & 0.3606 & 0.3513 & 0.4371 & 0.3860 \\
\hline 1976 & 0.3809 & 0.3804 & 0.4378 & 0.3912 \\
\hline 1977 & 0.3712 & 0.3902 & 0.4022 & 0.3863 \\
\hline 1978 & 0.3650 & 0.4121 & 0.3640 & 0.3796 \\
\hline 1979 & 0.3471 & 0.3970 & 0.3180 & 0.3691 \\
\hline 1980 & 0.3157 & 0.3641 & 0.2922 & 0.3677 \\
\hline 1981 & 0.3043 & 0.3745 & 0.3046 & 0.3595 \\
\hline 1982 & 0.2970 & 0.3665 & 0.3142 & 0.3688 \\
\hline 1983 & 0.2949 & 0.3989 & 0.3369 & 0.3788 \\
\hline 1984 & 0.2736 & 0.4050 & 0.3239 & 0.3813 \\
\hline 1985 & 0.2446 & 0.4003 & 0.3122 & 0.3793 \\
\hline 1986 & 0.2380 & 0.4348 & 0.2975 & 0.3173 \\
\hline 1987 & 0.2316 & 0.4503 & 0.2600 & 0.3107 \\
\hline 1988 & 0.2031 & 0.4800 & 0.2134 & 0.3069 \\
\hline 1989 & 0.1654 & 0.5242 & 0.1900 & 0.2976 \\
\hline 1990 & 0.1269 & 0.5079 & 0.1726 & 0.2745 \\
\hline 1991 & 0.1333 & 0.4784 & 0.1820 & 0.2757 \\
\hline 1992 & 0.1386 & 0.4884 & 0.1830 & 0.2806 \\
\hline 1993 & 0.1452 & 0.4983 & 0.1986 & 0.2755 \\
\hline 1994 & 0.1496 & 0.4865 & 0.1915 & 0.2861 \\
\hline 1995 & 0.1431 & 0.4768 & 0.2042 & 0.2878 \\
\hline 1996 & 0.1311 & 0.4523 & 0.1943 & 0.2850 \\
\hline 1997 & 0.1256 & 0.4311 & 0.1841 & 0.2899 \\
\hline
\end{tabular}

Source: Authors' calculations using the Japan Development Bank Database of companies listed on the major Japanese stock exchanges. 
Table 7

Quarterly Financial Reports data on the Ratio of Bank Debt to Assets for U.S. Firms (Large Manufacturing firms are defined as having nominal assets $>\$ 10$ million)

\begin{tabular}{|l|l|l|l|l|l|l|}
\hline $\begin{array}{l}\text { Year } \\
\text { 4th quarter) }\end{array}$ & $\begin{array}{l}\text { All } \\
\text { Manufacturing }\end{array}$ & $\begin{array}{l}\text { Large } \\
\text { Manufacturing. }\end{array}$ & $\begin{array}{l}\text { Small } \\
\text { Manufacturing. }\end{array}$ & Wholesale & Retail & $\begin{array}{l}\text { All } \\
\text { Industries }\end{array}$ \\
\hline 1979 & 0.0660 & 0.0550 & 0.1642 & 0.1777 & 0.1255 & 0.0919 \\
\hline 1980 & 0.0680 & 0.0575 & 0.1688 & 0.1882 & 0.1206 & 0.0937 \\
\hline 1981 & 0.0665 & 0.0568 & 0.1676 & 0.1844 & 0.0637 & 0.0850 \\
\hline 1982 & 0.0712 & 0.0617 & 0.1695 & 0.2383 & 0.0546 & 0.0829 \\
\hline 1983 & 0.0644 & 0.0542 & 0.1710 & 0.2028 & 0.0524 & 0.0746 \\
\hline 1984 & 0.0754 & 0.0652 & 0.1860 & 0.1995 & 0.0553 & 0.0839 \\
\hline 1985 & 0.0731 & 0.0632 & 0.1867 & 0.1825 & 0.0681 & 0.0820 \\
\hline 1986 & 0.0796 & 0.0714 & 0.1878 & 0.1773 & 0.0797 & 0.0882 \\
\hline 1987 & 0.0830 & 0.0751 & 0.1892 & 0.1865 & 0.0922 & 0.0932 \\
\hline 1988 & 0.0950 & 0.0875 & 0.2045 & 0.1886 & 0.1296 & 0.1064 \\
\hline 1989 & 0.1004 & 0.0944 & 0.1988 & 0.1937 & 0.1434 & 0.1130 \\
\hline 1990 & 0.1032 & 0.0976 & 0.2009 & 0.1868 & 0.1417 & 0.1146 \\
\hline 1991 & 0.0954 & 0.0899 & 0.1954 & 0.1771 & 0.1287 & 0.1064 \\
\hline 1992 & 0.0924 & 0.0875 & 0.1831 & 0.1786 & 0.0968 & 0.1007 \\
\hline 1993 & 0.0863 & 0.0814 & 0.1771 & 0.1671 & 0.0916 & 0.0945 \\
\hline 1994 & 0.0850 & 0.0798 & 0.1868 & 0.1676 & 0.0932 & 0.0940 \\
\hline 1995 & 0.0862 & 0.0809 & 0.1934 & 0.1703 & 0.0993 & 0.0961 \\
\hline 1996 & 0.0834 & 0.0782 & 0.1910 & 0.1623 & 0.1026 & 0.0932 \\
\hline 1997 & 0.0877 & 0.0834 & 0.1794 & 0.1513 & 0.1089 & 0.0966 \\
\hline
\end{tabular}

Source: Quarterly Financial Report for Manufacturing, Mining, and Trade Corporations (QFR) produced by Bureau of Census. For manufacturing firms all corporations with total assets of $\$ 250$ and over are included in the survey. Smaller manufacturing firms are randomly sampled with sampling factors ranging from $1 / 2$ to $1 / 160$, depending on their sizes. We define large firms to be those with nominal assets greater than $\$ 10$ million. The sampling rules governing the inclusion of wholesale and retail trade firms has changed over time. In the 1979 and 1980 surveys, the rules for these sectors were the same as that for manufacturing. From the 1981 survey to the 1987 survey, only firms with assets above $\$ 25$ million were included. After 1988 on, firms had to have assets above $\$ 50$ million to be included. 
Table 8

Industry Level Comparisons of Bank Debt to Total Assets Ratio for Large U.S. and Japanese Manufacturing Firms

\begin{tabular}{|c|r|r|r|r|r|}
\hline Industry & US 1998 & Japan 1980 & Japan 1998 & Japan 1980 - US & Japan 1998 - US \\
\hline Food & 0.1216 & 0.1925 & 0.1369 & 0.0709 & 0.0153 \\
\hline Textile & 0.2014 & 0.3828 & 0.2465 & 0.1814 & 0.0451 \\
\hline Pulp \& Paper & 0.1167 & 0.4372 & 0.3535 & 0.3205 & 0.2368 \\
\hline Printing \& Publishing & 0.0860 & 0.0808 & 0.0852 & -0.0052 & -0.0008 \\
\hline Chemical & 0.0758 & 0.3145 & 0.1649 & 0.2387 & 0.0891 \\
\hline Petroleum \& Coal & 0.0240 & 0.5836 & 0.4168 & 0.5596 & 0.3928 \\
\hline Stone, Glass and Clay & 0.1531 & 0.3708 & 0.1941 & 0.2177 & 0.0410 \\
\hline Iron and Steel & 0.1138 & 0.3924 & 0.2647 & 0.2786 & 0.1509 \\
\hline Nonferrous Metals & 0.0726 & 0.4458 & 0.3599 & 0.3732 & 0.2873 \\
\hline Metal Products & 0.1788 & 0.3150 & 0.1738 & 0.1362 & -0.0050 \\
\hline Machinery & 0.0725 & 0.2415 & 0.1568 & 0.1690 & 0.0843 \\
\hline Electronic Machinery & 0.0497 & 0.1542 & 0.0919 & 0.1045 & 0.0422 \\
\hline Transportation Durable & 0.0393 & 0.1479 & 0.1096 & 0.1086 & 0.0703 \\
\hline Precision Machinery & 0.1551 & 0.1647 & 0.1020 & 0.0096 & -0.0531 \\
\hline Average & 0.1043 & 0.3017 & 0.2040 & 0.1974 & 0.0997 \\
\hline
\end{tabular}

Source: See text.

Note: Large U.S. firms are defined as having assets $>\$ 25$ million 
Table 9

Industry Level Comparisons of Bank Debt to

Total Assets for Small U.S. and Japanese Manufacturing Firms

\begin{tabular}{|c|r|r|r|r|r|}
\hline Industry & US 1998 & Japan 1980 & Japan 1998 & Japan 1980 - US & Japan 1998 - US \\
\hline Food & 0.2637 & 0.3945 & 0.4877 & 0.1308 & 0.2240 \\
\hline Textile & 0.1971 & 0.3300 & 0.3460 & 0.1329 & 0.1489 \\
\hline Pulp \& Paper & 0.2334 & 0.2591 & 0.3910 & 0.0257 & 0.1576 \\
\hline Printing \& Publishing & 0.1958 & 0.3115 & 0.2600 & 0.1157 & 0.0642 \\
\hline Chemical & 0.1775 & 0.2095 & 0.2874 & 0.0320 & 0.1099 \\
\hline Petroleum \& Coal & 0.1763 & 0.3917 & 0.2576 & 0.2154 & 0.0813 \\
\hline Stone, Glass and Clay & 0.2246 & 0.3068 & 0.4302 & 0.0822 & 0.2056 \\
\hline Iron and Steel & 0.1910 & 0.2818 & 0.4137 & 0.0908 & 0.2227 \\
\hline Nonferrous Metals & 0.1977 & 0.2727 & 0.4078 & 0.0750 & 0.2101 \\
\hline Metal Products & 0.1814 & 0.2720 & 0.4000 & 0.0906 & 0.2186 \\
\hline Machinery & 0.1865 & 0.2622 & 0.3671 & 0.0757 & 0.1806 \\
\hline Electronic Machinery & 0.1771 & 0.2390 & 0.2632 & 0.0619 & 0.0861 \\
\hline Transportation Durable & 0.1795 & 0.2504 & 0.3271 & 0.0709 & 0.1476 \\
\hline Precision Machinery & 0.1295 & 0.2039 & 0.3236 & 0.0744 & 0.1941 \\
\hline Average & 0.1937 & 0.2847 & 0.3545 & 0.0910 & 0.1608 \\
\hline
\end{tabular}

Source: See text.

Note: Small U.S. firms are defined as having assets $<\$ 25$ million 
Table 10

Ratios of Bank Deposits to GDP for Selected Years - G7 Countries

\begin{tabular}{|l|c|c|c|c|c|c|}
\hline Country & Year & $\begin{array}{c}\text { (Demand } \\
\text { Deposits/GDP) }\end{array}$ & $\begin{array}{c}\text { (Time } \\
\text { Deposits/ } \\
\text { GDP) }\end{array}$ & $\begin{array}{c}\text { (Total Deposits/ } \\
\text { GDP) }\end{array}$ & $\begin{array}{c}\text { Addendum: } \\
\text { (Non-bank } \\
\text { Deposits/GDP) }\end{array}$ & $\begin{array}{c}\text { A.3 } \\
\text { (Total Deposits/ } \\
\text { Wealth) }\end{array}$ \\
\hline Canada & 1983 & 0.09 & 0.55 & 0.63 & 0.58 & 0.35 \\
\hline & 1996 & 0.17 & 0.62 & 0.79 & 0.75 & 0.33 \\
\hline France & 1983 & 0.18 & 0.43 & 0.61 & 0.46 & 0.57 \\
\hline & 1996 & 0.20 & 0.45 & 0.65 & 0.68 & 0.36 \\
\hline Germany & 1983 & 0.11 & 0.40 & 0.50 & 0.72 & 0.55 \\
\hline & 1996 & 0.18 & 0.42 & 0.60 & 0.93 & 0.43 \\
\hline Italy & 1983 & 0.31 & 0.36 & 0.67 & 0.59 & 0.35 \\
\hline & 1996 & 0.27 & 0.25 & 0.52 & 0.51 & 0.33 \\
\hline Japan & 1983 & 0.21 & 1.36 & 1.58 & 1.50 & 0.67 \\
\hline & 1996 & 0.28 & 1.78 & 2.06 & 1.43 & 0.62 \\
\hline U.K. & 1983 & 0.10 & 0.25 & 0.35 & 0.85 & N/A \\
\hline & 1996 & N/A & 1.06 & 1.06 & 0.91 & N/A \\
\hline U.S & 1983 & 0.11 & 0.46 & 0.57 & 0.74 & 0.25 \\
\hline & 1996 & 0.11 & 0.31 & 0.42 & 0.50 & 0.16 \\
\hline
\end{tabular}

Notes:

(1) International Financial Statistics, International Monetary Fund. This information includes all institutions that accept deposits, not only commercial banks.

(2) Bank Profitability:Financial Statements of Banks, Statistical Supplement, Organization for Economic Co-operation and Development, several issues.

(3) For U.K. the data corresponds to 1984. Also for U.K. and Japan, Non-Bank deposits include Interbank deposits.

(4) Financial Accounts of OECD countries, Organisation for Economic Cooperation and Development, several issues. 
Table 11

Profitability and Non Interest Income: Major U.S. Banks, 1976 - 1996

\begin{tabular}{|c|c|c|c|}
\hline YEAR & $\begin{array}{c}\text { \%Non-Interest } \\
\text { Income } \\
\end{array}$ & ROA & ROE \\
\hline 76 & 0.1053 & 0.0055 & 0.0919 \\
\hline 77 & 0.1024 & 0.0058 & 0.1013 \\
\hline 78 & 0.0967 & 0.0062 & 0.1106 \\
\hline 79 & 0.1377 & 0.0065 & 0.1185 \\
\hline 80 & 0.1294 & 0.0049 & 0.0889 \\
\hline 81 & 0.1171 & 0.0036 & 0.0297 \\
\hline 82 & 0.1271 & 0.0041 & 0.0481 \\
\hline 83 & 0.1431 & 0.0049 & 0.0634 \\
\hline 84 & 0.1093 & 0.0055 & 0.0759 \\
\hline 85 & 0.1325 & 0.0071 & 0.1287 \\
\hline 86 & 0.1448 & 0.0065 & 0.1040 \\
\hline 87 & 0.1506 & 0.0003 & -0.0135 \\
\hline 88 & 0.1513 & 0.0071 & 0.1468 \\
\hline 89 & 0.1472 & 0.0041 & -0.1150 \\
\hline 90 & 0.1527 & 0.0023 & 0.0534 \\
\hline 91 & 0.1864 & 0.0056 & 0.0783 \\
\hline 92 & 0.2213 & 0.0104 & 0.1384 \\
\hline 93 & 0.2465 & 0.0131 & 0.1684 \\
\hline 94 & 0.2373 & 0.0127 & 0.1691 \\
\hline 95 & 0.2246 & 0.0128 & 0.1645 \\
\hline 96 & 0.2535 & 0.0146 & 0.1670 \\
\hline
\end{tabular}

Notes: Data are taken from the December Call report for each year. Each entry is the average over the top $1 \%$ institutions (according to Total Assets of the respective ratio for each year. All the variable names in this footnote are extracted from the instructions for submitting Call Reports, 1976-1996.

Non interest income is the mean of non-interest income to total income ratio. Before 1984 , non-interest income is computed as total income (riad4000) minus interest income $\operatorname{riad} 4010, \operatorname{riad} 4020, \operatorname{riad} 4025$, riad4063, riad4065, riad40115). From 1984 onward, there is an specific account that keeps track of interest income: riad4107. Thus, from 1984 onward, we define non-interest income as riad4000 minus riad4107.

ROA is the mean of return on assets. Return on assets is computed as net income (riad4340) divided by total assets (rcfd2170).

ROE is the mean of return on equity. This ratio is computed as net income (riad4340) divided by total equity capital (rcfd3210). 
Table 12

Interest Income, Fee Income, Return on Assets and Return on Equity for Japanese City Banks

\begin{tabular}{|c|c|c|c|c|c|c|c|}
\hline Year & RINT & RLINT & RFEE & ROCUR & ROA1 & ROE1 & AROA \\
\hline & & & & & & & \\
1976 & 0.9317 & 0.7152 & 0.0359 & 0.0024 & NA & NA & NA \\
\hline 1977 & 0.9314 & 0.6980 & 0.0375 & 0.0028 & 0.0013 & 0.0528 & 0.0028 \\
\hline 1978 & 0.8967 & 0.6385 & 0.0415 & 0.0047 & 0.0012 & 0.0476 & 0.0026 \\
\hline 1979 & 0.8965 & 0.5876 & 0.0451 & 0.0031 & 0.0012 & 0.0484 & 0.0026 \\
\hline 1980 & 0.8987 & 0.5568 & 0.0347 & 0.0025 & 0.0007 & 0.0300 & 0.0013 \\
\hline 1981 & 0.9292 & 0.5760 & 0.0286 & 0.0019 & 0.0009 & 0.0425 & 0.0017 \\
\hline 1982 & 0.9320 & 0.5163 & 0.0298 & 0.0015 & 0.0022 & 0.1094 & 0.0047 \\
\hline 1983 & 0.9388 & 0.5192 & 0.0308 & 0.0014 & 0.0020 & 0.1030 & 0.0047 \\
\hline 1984 & 0.9362 & 0.5482 & 0.0323 & 0.0015 & 0.0024 & 0.1297 & 0.0053 \\
\hline 1985 & 0.9380 & 0.5091 & 0.0288 & 0.0014 & 0.0023 & 0.1190 & 0.0051 \\
\hline 1986 & 0.9236 & 0.5541 & 0.0319 & 0.0018 & 0.0022 & 0.1213 & 0.0044 \\
\hline 1987 & 0.8965 & 0.5301 & 0.0337 & 0.0030 & 0.0026 & 0.1341 & 0.0059 \\
\hline 1988 & 0.8463 & 0.4764 & 0.0323 & 0.0036 & 0.0030 & 0.1541 & 0.0070 \\
\hline 1989 & 0.8338 & 0.4867 & 0.0310 & 0.0940 & 0.0036 & 0.1617 & 0.0031 \\
\hline 1990 & 0.8690 & 0.4894 & 0.0267 & 0.0696 & 0.0027 & 0.1073 & 0.0009 \\
\hline 1991 & 0.9075 & 0.5857 & 0.0236 & 0.0364 & 0.0019 & 0.0683 & 0.0014 \\
\hline 1992 & 0.9103 & 0.6213 & 0.0242 & 0.0424 & 0.0014 & 0.0465 & 0.0022 \\
\hline 1993 & 0.9205 & 0.6091 & 0.0313 & 0.0153 & 0.0008 & 0.0248 & 0.0023 \\
\hline 1994 & 0.8482 & 0.5324 & 0.0355 & 0.0651 & 0.0007 & 0.0212 & -0.0012 \\
\hline 1995 & 0.8011 & 0.4679 & 0.0361 & 0.1224 & -0.0002 & -0.0046 & -0.0045 \\
\hline 1996 & 0.8074 & 0.3906 & 0.0363 & 0.0867 & -0.0042 & -0.1171 & -0.0077 \\
\hline 1997 & 0.7916 & 0.3710 & 0.0410 & 0.1188 & -0.0001 & -0.0040 & -0.0024 \\
\hline
\end{tabular}

Data are for the accounting year ending in March of each year.

RINT: Proportion of interest income in the current income

RLINT: Proportion of interest income on loans in the current income.

RFEE: Proportion of fee income in the current income.

ROCUR: Proportion of the other current income, including realized capital gains on securities.

ROA: After-tax net income divided by total assets from March of the previous year

ROE: After-tax net income divided by total capital (capital plus reserves) from March of the previous year

AROA: Adjusted ROA. (Current profits - gains from sales of the securities + losses from sales from the securities + losses from revaluation of securities) divided by total assets from March of the previous year 
Table 13

Regressions Relating Banks Return on Assets and Macroenomic Variables Dependent Variable is Citi Banks Adjusted Retum on Assets, Sample Period is 1957 - 1983

\begin{tabular}{|c|c|c|c|c|}
\hline Variable & $\begin{array}{l}\text { Coefficient } \\
\text { (t-statistic) }\end{array}$ & $\begin{array}{l}\text { Coefficient } \\
\text { (t-statistic) }\end{array}$ & $\begin{array}{l}\text { Coefficient } \\
\text { (t-statistic) }\end{array}$ & $\begin{array}{l}\text { Coefficient } \\
\text { (t-statistic) }\end{array}$ \\
\hline Intercept & $\begin{array}{c}0.01138 \\
5.833\end{array}$ & $\begin{array}{l}0.01182 \\
5.951\end{array}$ & $\begin{array}{c}0.00337 \\
0.990\end{array}$ & $\begin{array}{c}0.00413 \\
1.122\end{array}$ \\
\hline Time Trend & $\begin{array}{l}-0.00026 \\
-3.645\end{array}$ & $\begin{array}{l}-0.00028 \\
-4.039\end{array}$ & $\begin{array}{l}-0.00009 \\
-0.982\end{array}$ & $\begin{array}{c}-0.00010 \\
-1.018\end{array}$ \\
\hline Real GDP growth & $\begin{array}{c}-0.00377 \\
-0.331 \\
\end{array}$ & $\begin{array}{l}-0.00359 \\
-0.295\end{array}$ & $\begin{array}{l}-0.00255 \\
-0.263\end{array}$ & $\begin{array}{c}-0.00020 \\
-0.018\end{array}$ \\
\hline Real GDP growth (t-1) & $\begin{array}{c}0.00479 \\
0.456 \\
\end{array}$ & $\begin{array}{c}0.00343 \\
0.359 \\
\end{array}$ & $\begin{array}{c}0.01993 \\
1.893 \\
\end{array}$ & $\begin{array}{c}0.01432 \\
1.495 \\
\end{array}$ \\
\hline $\begin{array}{l}\text { Log change in real } \\
\text { average land price }\end{array}$ & $\begin{array}{c}-0.00584 \\
-0.761 \\
\end{array}$ & . & $\begin{array}{c}-0.01355 \\
-1.906 \\
\end{array}$ & . \\
\hline $\begin{array}{l}\text { Log change in real } \\
\text { average land price (t-1) }\end{array}$ & $\begin{array}{c}0.00646 \\
1.281 \\
\end{array}$ & $\cdot$ & $\begin{array}{c}0.00861 \\
1.981 \\
\end{array}$ & . \\
\hline $\begin{array}{l}\text { Log change in real } \\
\text { urban land price }\end{array}$ & . & $\begin{array}{l}-0.00299 \\
-0.654\end{array}$ & . & $\begin{array}{c}-0.00634 \\
-1.487\end{array}$ \\
\hline $\begin{array}{l}\text { Log change in real } \\
\text { urban land price }(\mathrm{t}-1)\end{array}$ & $\cdot$ & $\begin{array}{c}0.00241 \\
0.671\end{array}$ & . & $\begin{array}{c}0.00369 \\
1.149\end{array}$ \\
\hline Real call rate & $\begin{array}{c}0.00620 \\
0.518 \\
\end{array}$ & $\begin{array}{c}0.00501 \\
0.423 \\
\end{array}$ & $\begin{array}{c}0.01547 \\
1.442 \\
\end{array}$ & $\begin{array}{c}0.01166 \\
1.080 \\
\end{array}$ \\
\hline Real call rate(t-1) & $\begin{array}{l}-0.00862 \\
-0.971\end{array}$ & $\begin{array}{l}-0.00983 \\
-1.039\end{array}$ & $\begin{array}{l}-0.00495 \\
-0.648\end{array}$ & $\begin{array}{l}-0.00725 \\
-0.864\end{array}$ \\
\hline ROA (t-1) & $\cdot$ & & $\begin{array}{c}0.53427 \\
2.693 \\
\end{array}$ & $\begin{array}{c}0.48948 \\
2.375 \\
\end{array}$ \\
\hline $\begin{array}{l}\text { Log change in real equity } \\
\text { prices }\end{array}$ & $\begin{array}{c}0.00370 \\
2.088 \\
\end{array}$ & $\begin{array}{r}0.00362 \\
2.159 \\
\end{array}$ & $\begin{array}{c}0.00392 \\
2.608 \\
\end{array}$ & $\begin{array}{r}0.00343 \\
2.319\end{array}$ \\
\hline $\begin{array}{l}\text { Log change in real equity } \\
\text { prices }(t-1)\end{array}$ & $\begin{array}{c}0.00248 \\
0.973 \\
\end{array}$ & $\begin{array}{r}0.00273 \\
1.089 \\
\end{array}$ & $\begin{array}{c}0.00201 \\
0.928 \\
\end{array}$ & $\begin{array}{c}0.0019 ! \\
0.857 \\
\end{array}$ \\
\hline $\mathrm{R}^{2}$ & 0.8259 & 0.8144 & 0.8826 & 0.8651 \\
\hline \multicolumn{5}{|c|}{ P-values from exclusion tests for the sum of the coefficients on } \\
\hline $\begin{array}{l}\text { GDP growth } \\
\text { Land Prices } \\
\text { Interest rates } \\
\text { Equity Prices } \\
\end{array}$ & $\begin{array}{l}0.9432 \\
0.9274 \\
0.8467 \\
0.1113 \\
\end{array}$ & $\begin{array}{l}0.9916 \\
0.8858 \\
0.6896 \\
0.0820 \\
\end{array}$ & $\begin{array}{l}0.2135 \\
0.4271 \\
0.3743 \\
0.0756 \\
\end{array}$ & $\begin{array}{l}0.3381 \\
0.4743 \\
0.6972 \\
0.0994 \\
\end{array}$ \\
\hline \multicolumn{5}{|c|}{ P-values for tests of the equality of coefficients after 1984} \\
\hline Full 1984-1997 sample & 0.0149 & 0.0241 & 0.0298 & 0.0658 \\
\hline
\end{tabular}




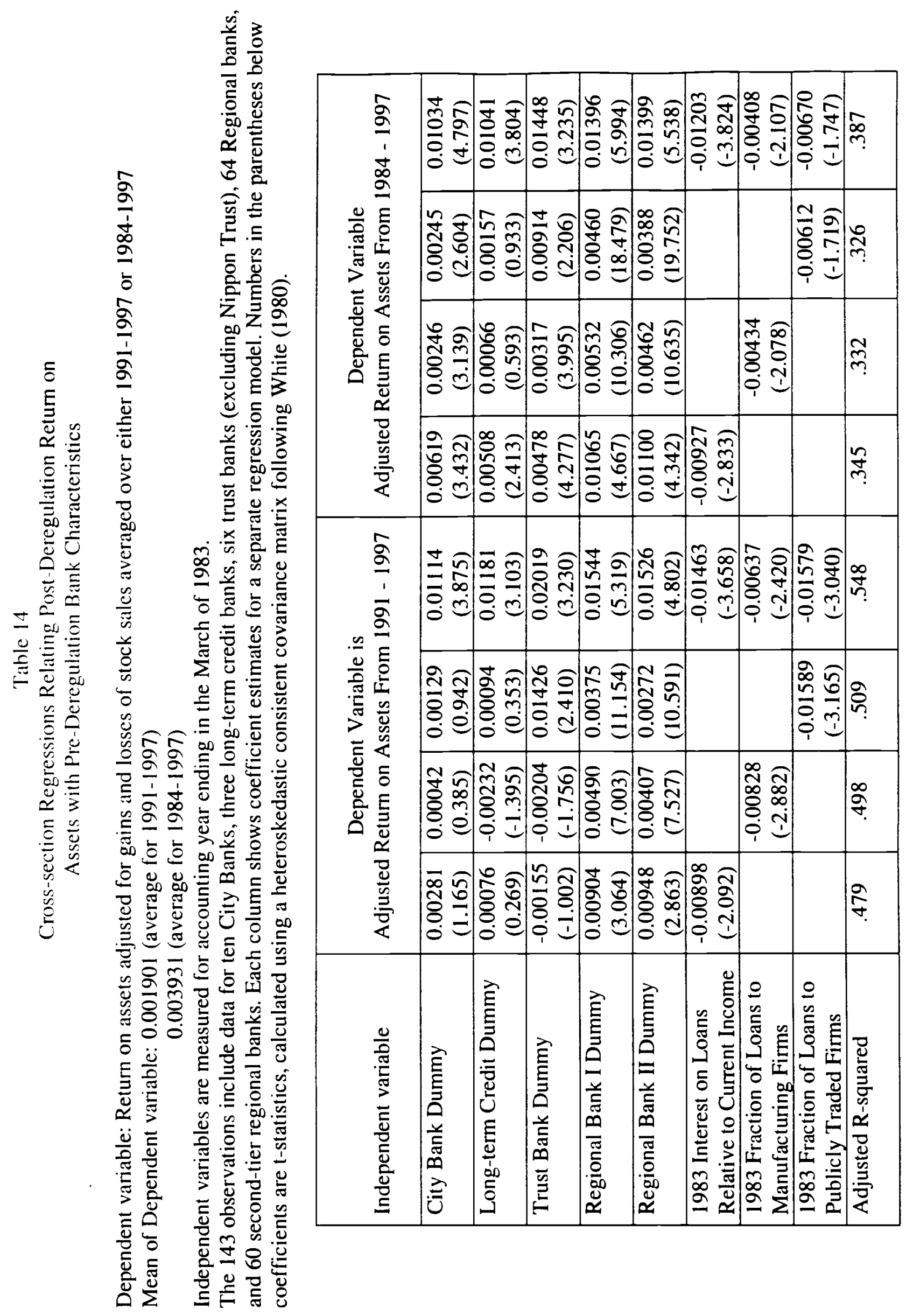




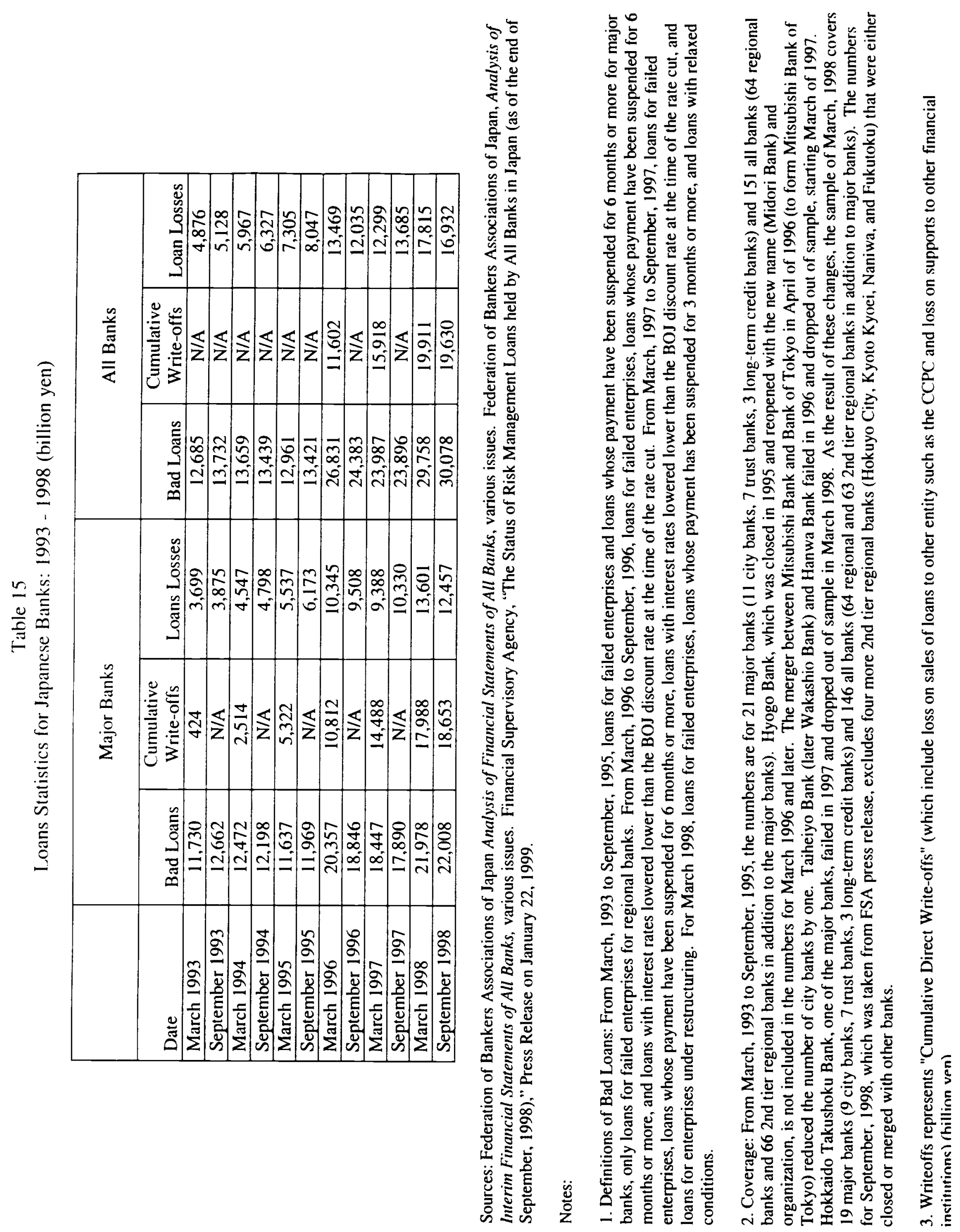


Table 16

Distribution of Loans by Supervisory Classification

There are 4 loan categories used by bank supervisors. Category 4 includes the loans that are non-collectable or of no-value. Category 3 is the set of loans that have serious concerns in terms of their ultimate collection. In practice these loans are also expected to return nothing. Category 2 loans are "credits subject to specific management risk". These loans are not yet judged to be uncollectible but are deemed to require special attention. Category 1 covers the remaining loans whose repayment is not supposed to be in any doubt. (See text for further details.)

Banks' 1998 Self-Reported Data

\begin{tabular}{|c|c|c|c|c|c|c|}
\hline \multicolumn{2}{|c|}{} & \multicolumn{4}{|c|}{ Supervisory Classification } & \\
\hline Sample & Date & 1 & 2 & 3 & 4 & Total Loans \\
\hline $\begin{array}{c}\text { Major } \\
\text { Banks }\end{array}$ & March 98 & 371,607 & 45,157 & 4,808 & 125 & 421,697 \\
\hline $\begin{array}{c}\text { All } \\
\text { Banks }\end{array}$ & March 98 & 544,814 & 65,488 & 6,065 & 130 & 616,495 \\
\hline $\begin{array}{c}\text { Major } \\
\text { Banks }\end{array}$ & Sept. 98 & 354,629 & 45,537 & 5,697 & 77 & 405,940 \\
\hline $\begin{array}{c}\text { All } \\
\text { Banks }\end{array}$ & Sept. 98 & 524,980 & 66,078 & 6,863 & 86 & 598,007 \\
\hline
\end{tabular}

Source: Financial Supervisory Agency, "The Status of Risk Management Loans held by All Banks in Japan (as of the end of September, 1998)," Press Release on January 22, 1999. The figures include loans of Long-Term Credit Bank and Nippon Credit Bank, but exclude those of Hokkaido Takushoku Bank, Tokuyo City Bank, Kyoto Kyoei Bank, Naniwa Bank, Fukutoku Bank, and Midori Bank.

March 1998 data for 19 major banks as determining by FSA audits (billion yen, published in December, 1998)

\begin{tabular}{|c|c|c|c|c|}
\hline \multicolumn{4}{|c|}{ Supervisory Classification } & \multirow[t]{2}{*}{ Total Loans } \\
\hline 1 & 2 & 3 & 4 & \\
\hline 364,332 & 48,971 & 7,756 & 637 & 421,696 \\
\hline
\end{tabular}

Source: Financial Supervisory Agency web site (www.fsa.go.jp), note these figures include loans of the Long Term Credit Bank and Nippon Credit Bank. 
Table 17

Review of Selected Countries Banking Problems, 1980 - 1996

\begin{tabular}{|c|c|c|c|c|}
\hline Country & Period & $\begin{array}{l}\text { Non- } \\
\text { performing } \\
\text { Loans }^{1}\end{array}$ & $\begin{array}{l}\text { Fiscal } \\
\text { Cost }^{2}\end{array}$ & Comments \\
\hline Argentina & $\begin{array}{l}1980-82 \\
1989-90 \\
1995 \\
\end{array}$ & $\begin{array}{c}9 \% \\
27 \% \\
\\
\text { N/A } \\
\end{array}$ & $\begin{array}{r}4 \% \\
\text { N/A } \\
\text { N/A } \\
\end{array}$ & $\begin{array}{l}37 \% \text { of state-owned banks were non-performing } \\
\text { Failed banks held } 40 \% \text { of financial system assets } \\
45 \text { of } 205 \text { institutions were closed or merged }\end{array}$ \\
\hline Australia & 1989-92 & $6 \%$ & $1.90 \%$ & \\
\hline Brazil & $1994-96$ & & & \\
\hline Chile & $1981-87$ & $16 \%$ & $19 \%$ & $\begin{array}{l}8 \text { banks intervened in } 1981 \text { ( } 33 \% \text { of outstanding loans, } \\
11 \text { in } 1982-83 \text { ( } 45 \% \text { of outstanding loans) }\end{array}$ \\
\hline Colombia & $1982-85$ & $15 \%$ & $5 \%$ & \\
\hline Czech Rep. & $\begin{array}{l}1991- \\
\text { Present }\end{array}$ & $38 \%$ & $12 \%$ & \\
\hline Finland & 1991-94 & $13 \%$ & $8 \%$ & Liquidity crisis in 1991 \\
\hline France & 1991-95 & $9 \%$ & $1 \%$ & \\
\hline Indonesia & $1992-95$ & $25 \%$ & $2 \%$ & $\begin{array}{l}\text { Non-performing loans concentrated in state-owned } \\
\text { banks }\end{array}$ \\
\hline Italy & $1990-95$ & $10 \%$ & N/A & \\
\hline South Korea & $\begin{array}{l}\text { Mid- } \\
\text { 1980s }\end{array}$ & $7 \%$ & $\mathrm{~N} / \mathrm{A}$ & \\
\hline Malaysia & $1985-88$ & $32 \%$ & $5 \%$ & Loans loss equivalent to $1.4 \%$ of GDP \\
\hline Mexico & $\begin{array}{l}1982 \\
1994- \\
\text { Present }\end{array}$ & $\begin{array}{l}\mathrm{N} / \mathrm{A} \\
12 \% \\
\end{array}$ & $\begin{array}{l}\text { N/A } \\
6 \% \\
\end{array}$ & Banking system nationalized \\
\hline Niger & $\begin{array}{l}\text { 1983- } \\
\text { Present }\end{array}$ & $50 \%$ & N/A & \\
\hline Norway & $1987-93$ & $6 \%$ & $3 \%$ & \\
\hline Philippines & $1981-87$ & $30 \%$ & $13 \%$ & \\
\hline Sweden & $1990-93$ & $18 \%$ & $4 \%$ & \\
\hline $\begin{array}{l}\text { United } \\
\text { States }\end{array}$ & $1980-92$ & $4 \%$ & $2 \%$ & 1142 S\&L institutions and 1395 banks were closed \\
\hline Uruguay & $1981-85$ & $59 \%$ & $31 \%$ & \\
\hline Venezuela & $\begin{array}{l}\text { 1994- } \\
\text { Present } \\
\end{array}$ & N/A & $17 \%$ & \\
\hline
\end{tabular}

Sources: IMF (1998c) and Lindgren, Garcia and Saal (1996).

Notes:

(1) Estimated at peak of the crisis, in percentage of total loans.

(2) Estimated in percentage of annual GDP during the restructuring period. 
Table 18

Distribution of the 1998 Quantity of Bank Borrowing and the Ratio of Bank Debt to Assets for Japanese Firms

Large firms have book value of equity greater than 1 billion yen

\begin{tabular}{|c|c|c|c|}
\hline Sample & $\begin{array}{l}\text { Total Bank } \\
\text { Borrowing (trillion } \\
\text { yen) }\end{array}$ & $\begin{array}{l}\text { Ratio of Bank } \\
\text { Debt to Assets }\end{array}$ & $\begin{array}{l}\text { Within category } \\
\text { \% accounted for } \\
\text { by small } \\
\text { borrowers }\end{array}$ \\
\hline All firms, all industries & 445 & 0.3567 & 0.6432 \\
\hline Large firms, all industries & 159 & 0.2761 & \\
\hline Small firms, all industries & 286 & 0.4257 & \\
\hline All firms, manufacturing & 92 & 0.2372 & 0.5738 \\
\hline Large firms, manufacturing & 39 & 0.1647 & \\
\hline Small firms, manufacturing & 53 & 0.3527 & \\
\hline All firms, wholesale trade & 65 & 0.3392 & 0.7160 \\
\hline Large firms, wholesale trade & 19 & 0.3027 & \\
\hline Small firms, wholesale trade & 46 & 0.3562 & \\
\hline All firms, retail trade & 41 & 0.411 & 0.8193 \\
\hline Large firms, retail trade & 7 & 0.2559 & \\
\hline Small firms, retail trade & 34 & 0.4746 & \\
\hline All firms, other industries & 247 & 0.4348 & 0.6207 \\
\hline Large firms, other industries & 94 & 0.3796 & \\
\hline Small firms, other industries & 153 & 0.4773 & \\
\hline
\end{tabular}

Source: Ministry of Finance, Hojin Kigyo Tokei. The firms included in the other category are all those which are not in manufacturing, wholesale trade, or retail trade. 
Table 19

Alternative Assumptions Regarding Loan Demand Used

for Calculating Steady Loan Amounts

\begin{tabular}{|l|l|l|}
\hline $\begin{array}{l}\text { Sector(s) } \\
\text { directly } \\
\text { affected }\end{array}$ & Short-hand name & Brief Description \\
\hline Manufacturing & $\begin{array}{l}\text { Simple manufacturing } \\
\text { convergence }\end{array}$ & $\begin{array}{l}\text { Large and small Japanese manufacturing firms } \\
\text { bank dependence converges to U.S. levels }\end{array}$ \\
\hline Manufacturing & $\begin{array}{l}\text { Industry-adjusted } \\
\text { manufacturing } \\
\text { convergence }\end{array}$ & $\begin{array}{l}\text { Within each of 15 manufacturing industries } \\
\text { large and small Japanese firms' bank } \\
\text { dependence converges to the U.S. levels }\end{array}$ \\
\hline $\begin{array}{l}\text { Rholesale and } \\
\text { Retail Trade }\end{array}$ & $\begin{array}{l}\text { Small trade firms } \\
\text { borrowing based on U.S. } \\
\text { manufacturing }\end{array}$ & $\begin{array}{l}\text { The ratio of bank dependence between U.S. } \\
\text { large and small manufacturing is imposed to } \\
\text { infer the target level of borrowing for small } \\
\text { trade firms }\end{array}$ \\
\hline $\begin{array}{l}\text { Wholesale and } \\
\text { Retail Trade }\end{array}$ & $\begin{array}{l}\text { Small trade firms } \\
\text { borrowing based on } \\
\text { current Japanese patterns }\end{array}$ & $\begin{array}{l}\text { The existing ratio of bank dependence between } \\
\text { large and small firms within each sector is } \\
\text { imposed to infer the target level of borrowing } \\
\text { for small firms in each sector. }\end{array}$ \\
\hline Other industries & Half way convergence & $\begin{array}{l}\text { Target levels for these firms are set to deliver an } \\
\text { equal percentage adjustment in bank } \\
\text { dependence for similar-sized trade firms. This } \\
\text { scenario covers half way convergence. }\end{array}$ \\
\hline $\begin{array}{l}\text { Other industries } \\
\text { equal percentage adjustment in bank } \\
\text { dependence for similar-sized trade firms. This } \\
\text { scenario covers full convergence. }\end{array}$ \\
Full convergence
\end{tabular}


Table 20

Implied Reductions in Lending for Japanese

Banks Assuming U.S. Borrowing Patterns

\begin{tabular}{|l|l|l|l|c|}
\hline $\begin{array}{l}\text { Assumption for } \\
\text { manufacturing } \\
\text { firms }\end{array}$ & $\begin{array}{l}\text { Assumption for } \\
\text { target of small } \\
\text { trade firms }\end{array}$ & $\begin{array}{l}\text { Assumption for } \\
\text { target level in } \\
\text { other industries }\end{array}$ & $\begin{array}{l}\text { Implied \% } \\
\text { Decrease in } \\
\text { Lending }\end{array}$ & $\begin{array}{l}\text { Fraction of Total } \\
\text { Lending to Small } \\
\text { Firms }\end{array}$ \\
\hline $\begin{array}{l}\text { Simple } \\
\text { convergence }\end{array}$ & $\begin{array}{l}\text { Based on U.S. } \\
\text { manufacturing }\end{array}$ & Full convergence & $41.5 \%$ & $70.6 \%$ \\
\hline $\begin{array}{l}\text { Simple } \\
\text { convergence }\end{array}$ & $\begin{array}{l}\text { Based on US } \\
\text { manufacturing }\end{array}$ & $1 / 2$ convergence & $29.8 \%$ & $67.4 \%$ \\
\hline $\begin{array}{l}\text { Simple } \\
\text { convergence }\end{array}$ & $\begin{array}{l}\text { Based on current } \\
\text { Japanese patterns }\end{array}$ & Full convergence \\
\hline $\begin{array}{l}\text { Simple } \\
\text { convergence }\end{array}$ & $\begin{array}{l}\text { Based on } \\
\text { current Japanese } \\
\text { patterns }\end{array}$ & $1 / 2$ convergence & $37.5 \%$ & $63.8 \%$ \\
\hline $\begin{array}{l}\text { Industry adjusted } \\
\text { convergence }\end{array}$ & $\begin{array}{l}\text { Based on U.S. } \\
\text { manufacturing }\end{array}$ & Full convergence & $41.6 \%$ & $63.4 \%$ \\
\hline $\begin{array}{l}\text { Industry adjusted } \\
\text { convergence }\end{array}$ & $\begin{array}{l}\text { Based on U.S. } \\
\text { manufacturing }\end{array}$ & $1 / 2$ convergence & $29.9 \%$ & $71.3 \%$ \\
\hline $\begin{array}{l}\text { Industry adjusted } \\
\text { convergence }\end{array}$ & $\begin{array}{l}\text { Based on current } \\
\text { Japanese patterns }\end{array}$ & Full convergence & $52.5 \%$ & $68.0 \%$ \\
\hline $\begin{array}{l}\text { Industry adjusted } \\
\text { convergence }\end{array}$ & $\begin{array}{l}\text { Based on current } \\
\text { Japanese patterns }\end{array}$ & $1 / 2$ convergence & $37.5 \%$ & $64.7 \%$ \\
\hline
\end{tabular}

Calculations assume that Japanese firms borrowing patterns move towards U.S. levels.

Benchmarks for the U.S. are taken from QFR for the 2nd quarter of 1998 . For categories where the QFR data are not sufficient, the assumptions shown in columns two and three are used.

These assumptions are described more fully in the text and briefly in Table 19. 